\title{
COMPETITION IN RETAIL BANKING SERVICES IN LATIN AMERICA
}

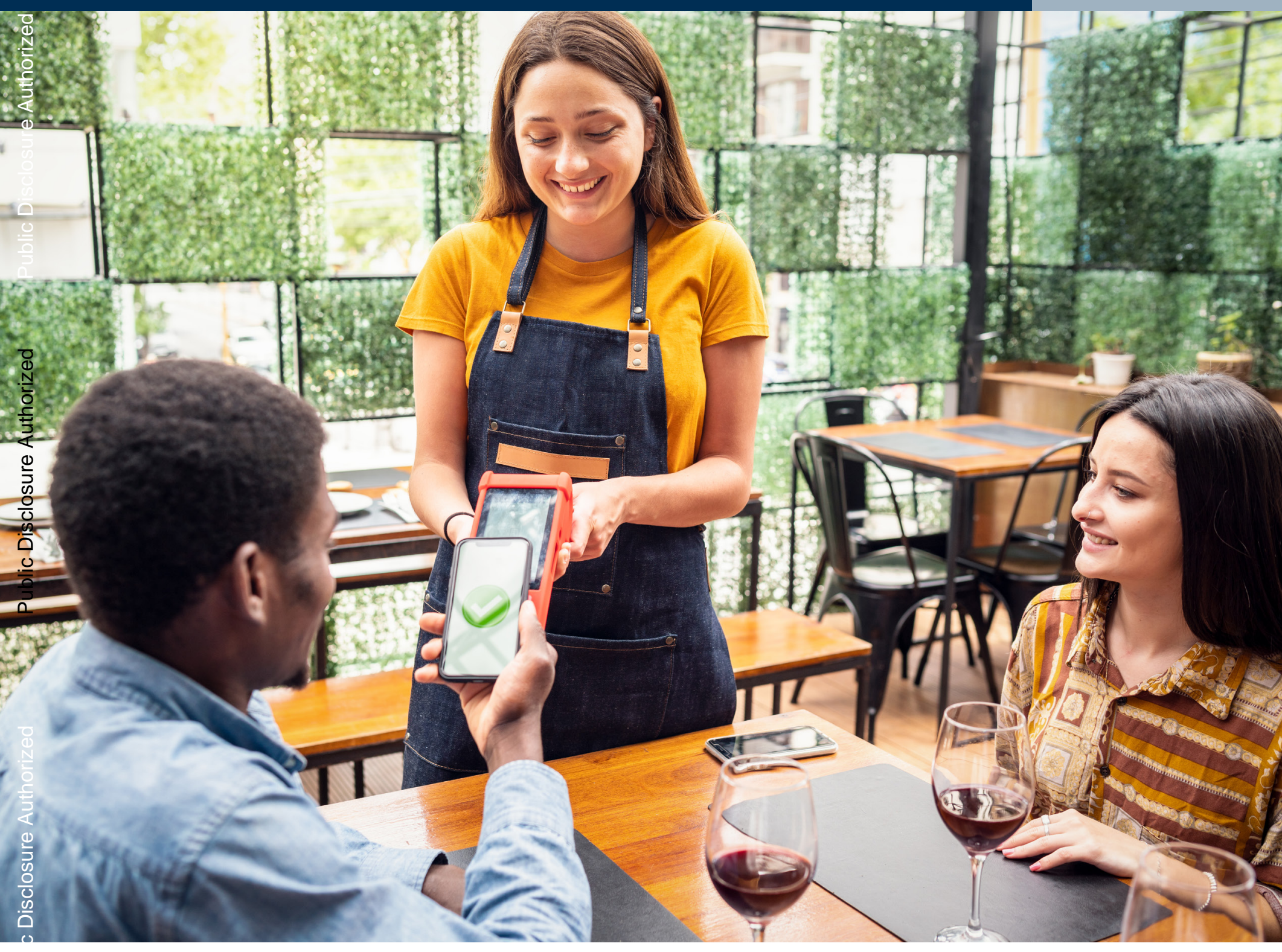


(C) 2020 International Bank for Reconstruction and Development / The World Bank 1818 H Street NW

Washington DC 20433

Telephone: 202-473-1000

Internet: www.worldbank.org

This work is a product of the staff of The World Bank with external contributions. The findings, interpretations, and conclusions expressed in this work do not necessarily reflect the views of The World Bank, its Board of Executive Directors, or the governments they represent.

The World Bank does not guarantee the accuracy of the data included in this work. The boundaries,colors, denominations, and other information shown on any map in this work do not imply any judgment on the part of The World Bank concerning the legal status of any territory or the endorsement or acceptance of such boundaries.

Rights and Permissions

The material in this work is subject to copyright. Because The World Bank encourages dissemination of its knowledge, this work may be reproduced, in whole or in part, for noncommercial purposes as long as full attribution to this work is given.

Any queries on rights and licenses, including subsidiary rights, should be addressed to World Bank Publications, The World Bank Group, 1818 H Street NW, Washington, DC 20433, USA; fax: 202522-2625; e-mail: pubrights@worldbank.org. 


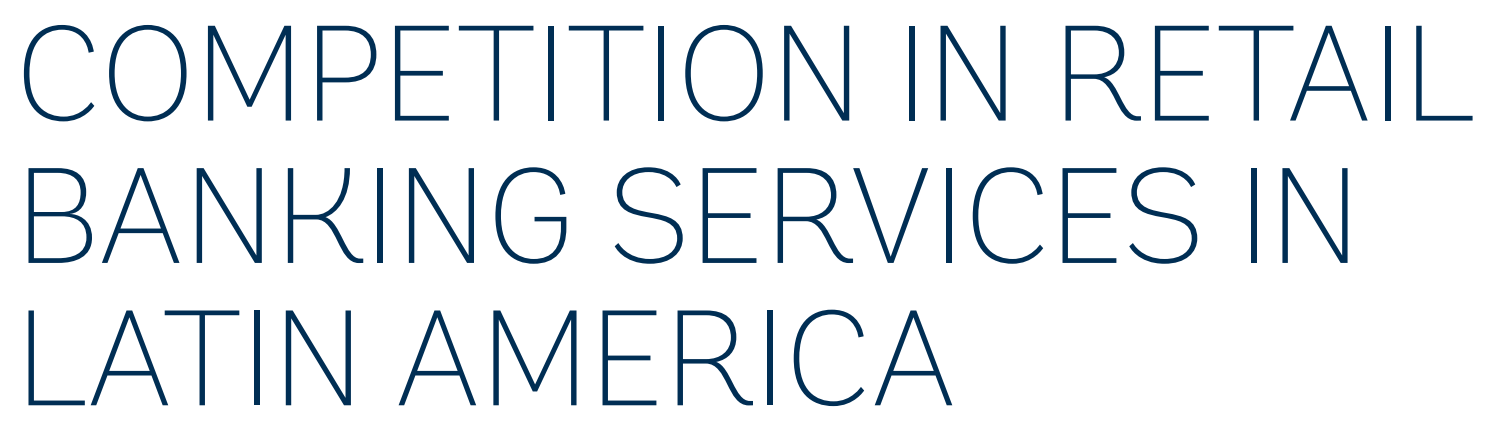




\section{CONTENTS}

\section{Acronyms}

Acknowledgments

Executive Summary

Introduction

Chapter 1: Market Structure, Contestability, and Pricing Power in Retail Banking in Latin America

1.1 Entry, exit, and contestability in banking services in LA-7

1.2 Pricing and market structure in retail banking in LA-5

1.3 Relating concentration to pricing power in retail banking in LA-5 18

$\begin{array}{ll}1.4 \text { Conclusion } & 20\end{array}$

Chapter 2: Contestability of Payment and Information Networks in Latin America 23

$\begin{array}{ll}2.1 \text { Payment systems } & 24\end{array}$

2.1.1 General competition aspects of payment infrastructure $\quad 24$

2.1.2 Competition aspects in the electronic transfers market $\quad 27$

2.1.3 Competition aspects in the cards market 33

2.1.4 Other competition related aspects beyond infrastructure access 39

$\begin{array}{lr}2.2 \text { Credit reporting systems } & 40\end{array}$

$\begin{array}{ll}\text { 2.2.1 General issues } & 40\end{array}$

$\begin{array}{ll}\text { 2.2.2 Regulatory barriers } & 40\end{array}$

2.2.3 Behavioral barriers $\quad 44$

2.2.4 Other informational practices that might affect competition in the retail banking market 46

$\begin{array}{ll}2.3 \text { Conclusion } & 46\end{array}$

Chapter 3: Competition Policy in Banking Services in Latin America 49

$\begin{array}{ll}3.1 \text { Competition policy mandates and regulatory powers } & 50\end{array}$

3.2 Implementation of competition mandates $\quad 51$

3.3 Cooperation and concurrence between competition and banking regulatory authorities 58

3.4 Competition policy during crises $\quad 66$

$\begin{array}{ll}3.5 \text { Conclusion } & 68\end{array}$

$\begin{array}{lr}\text { References } & 69\end{array}$

Annex I: Modelling the Relationship between Concentration and Pricing Power 75

$\begin{array}{lr}\text { Annex II: References on Legal and Institutional Frameworks } & 81\end{array}$ 
Figure 1.1: Costs of financial intermediation in Latin America

Figure 1.2: Analytical framework for assessing competition

Figure 2: Market structure

Figure 3: Regulatory indicators of contestability

Figure 4: Lerner index (\%)

Figure 5: Number of banks by country and year 12

Figure 6: Distribution of the contractual rates by country 13

Figure 7: Evolution over time of the median contractual rates by country 14

Figure 8: Evolution over time of the concentration index by product and country $\quad 15$

Figure 9: Persistence of market shares over a two-year period 17

Figure 10: Turnover at the top over a three-year period 17

Figure 11: Difference between contractual rates and money market rates (percentage points) 18

Figure 12: Relationship between pricing power and market share $\quad 19$

Figure 13: Payment system workflow and participants $\quad 24$

Figure 14: Card schemes $\quad 35$

$\begin{array}{lr}\text { Figure 15: Type of laws regulating CRSs } & 41\end{array}$

Figure 16: Ownership structure of CRS $\quad 45$

Figure 17: Positive data sharing in CRS $\quad 46$

Figure 18: Scope of mandate of banking regulators $\quad 59$

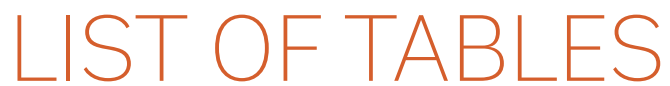

Table 1: Usage of digital transactions in Latin America $\quad 25$

Table 2: Credit and debit card ownership and usage $\quad 34$

Table 3: Credit and debit card ownership by segment $\quad 34$

Table 4: CRS in LA-7 142

Table 5: Competition enforcement tools in Latin America

Table 6: Advocacy and enforcement activities $\quad 57$

Table 7: Division of labor between the competition authority and the financial regulator 60

Table A1: Descriptive statistics bank-level variables $\quad 76$

Table A2: Estimations with product fixed effects $\quad 77$

$\begin{array}{ll}\text { Table A3: Country regressions with product fixed effects } & 78\end{array}$

Table A4: Estimations with time and bank fixed effects 79 
Box 1: Information security in Mexico's payment system

Box 2: Practices to limit access to essential components of the payments infrastructure

Box 3: Access to payment systems for nonbank entities

Box 4: Vertical integration in the cards market

Box 5: Practices that limit competition in the card market in LA-7

Box 6: Practices to promote competition in card markets

Box 7: Chile: CCS monopolistic practices through the BIC file $\quad 43$

Box 8: Implementation of privacy rules in Brazil $\quad 44$

Box 9: Relevant cases in antitrust enforcement, merger review, and advocacy initiatives in the EU 52

Box 10: Merger prohibition to safeguard competition in payment markets in Chile $\quad 54$

Box 11: Conglomerates in the Colombian financial sector $\quad 55$

Box 12: Recent investigation by Mexican competition authority into sovereign bond market 56

Box 13: Peru: Market study in payment systems as regulatory threat $\quad 56$

Box 14: Competition considerations for Mexican Fintech Bill $\quad 57$

Box 15: Coordination of policy implementation tools: U.K. concurrency framework and merger review model 61

Box 16: Other examples of coordination mechanism between competition authorities and banking regulators 62

Box 17: Case study: Merger review of Fukuoka Financial Group Inc. and the Eighteen Bank Ltd. 63

Box 18: Case study: Merger review in Australia during the global financial crisis 63

Box 19: Case study: Competition authority's decision power over banking mergers in Israel 64

Box 20: Jurisdictional delineation in Peruvian competition policy in the banking sector $\quad 64$

Box 21: Cooperation through an MoU between CADE and BCB-Itaú/XP merger 65

Box 22: Case study: Competition considerations in European state aid design 66

Box 23: Examples of exemptions granted for coordination in the banking sector to address the Covid-19 crisis 67 
ACCC

ACM

ANC

APRA

BCB

BCRP

BIC

BKA

BRSS

CCS

CIP

CMA

CNBV

CODI

COFECE

CRS

DEBIN

EC

EU

EURIBOR

FCA

FCCA

FNE

FSA

FSB

GDP

GFC

GFDD

GIC

GPCR

HHI

ICA

IFRS

INDECOPI
Australia Competition and Consumer Commission

Authority for Consumers and Markets

Autoridad Nacional de Competencia

Australia's Prudential Regulation Authority

Central Bank of Brazil

Banco Central de Reserva del Peru

Boletin de Informaciones Comerciales

Bundeskartellamt

Bank Regulation and Supervision Survey

Competition Commission of Singapore

Câmara Interbancária de Pagamentos

Competition and Markets Authority

Comisión Nacional de Banca y Valores

Cobro Digital

Comisión Federal de Competencia Económica

Credit Reporting System

Débito Inmediato

European Commission

European Union

Euro Interbank Offered Rate

Financial Conduct Authority

Finnish Competition and Consumer Authority

Fiscalia Nacional Económica

Financial Services Agency

Financial Stability Board

Gross Domestic Product

Global Financial Crisis

Global Financial Development Database

Gestora de Inteligencia de Credito

General Principles for Credit Reporting

Herfindahl-Hirschman Index

Israel Competition Authority

International Financial Reporting Standards

Instituto Nacional de Defensa de la Competencia y de la Protección de la Propiedad Intelectual 
JFTC Japan Fair Trade Commission

MDR Merchant Discount Rate

MFI Microfinance Institution

MNO Mobile Network Operator

MOU Memorandum of Understanding

NFC Near-field Communication

OECD Organisation for Economic Co-operation and Development

PEI

Pago Electrónico Inmediato

PES

Pago Seguro en Linea

POS Point of Sale

PRA Prudential Regulation Authority

PSR Payment Systems Regulator

RAI

Registro de Aceptaciones Impagadas

RBA

Reserve Bank of Australia

SBS

Superintendencia Nacional de Banca, Seguros y AFP

SFC

Superintendencia Financiera de Colombia

SIC

Superintendencia de Industria y Comercio

SMES

Small and Medium Enterprises

SOS

Secretary of State

SPEI

Sistema de Pagos Electrónicos Interbancarios

STR

Sistema de Transferência de Reservas

USSD

Unstructured Supplementary Service Data 
This report was prepared by a team led by Pietro Calice (ELCFN) and comprising Noelia Carreras (ETICI), Federico Diaz Kalan (ELCFN), Guillermo Galicia (EFNFI), Tanja Goodwin (ETICI), Davide Mare (DECFP), and Fredes Montes (EFNFI). Outstanding research assistance was provided by Guillermo Rodriguez Ruiz (ELCFN). The team is grateful to Alfonso Garcia Mora (EFNDR) and Zafer Mustafaoglu (ELCFN) for their guidance. The team gratefully acknowledges comments and input provided by Steen Byskov (FABBK), Xavier Faz de los Santos (EFICG), Georgiana Pop (ETICI), Rodrigo Barajas (ETICI), Harish Natarajan (EFNFI), Luz Maria Salamina (EFNFI), and Mahesh Uttamchandani (EFNFI). The generous financial support of the FIRST Initiative is also acknowledged as is the support of Carlos Piñerúa (EFNFT) and Moni Sengupta (EFNFT). Last but not least, we are indebted to the country authorities and their staff for participating in the survey on which this study is partly based. Any inadvertent errors or omissions are only ours. 



\section{EXECUTIVE SUMMARY}

This paper analyzes competition in the retail banking markets in Latin

America. Retail banking services, that is banking products and services for consumers and small businesses - including deposit accounts and related services such as ATMs, direct debit and credit transfers, and credit lines - are an increasingly important segment of the banking business in the region. Yet the provision of banking services in Latin America remains very expensive by international comparison. While many factors contribute to high costs of financial intermediation in the region, restricted or distorted competition may be an important supply-side driver. Based on a survey with competition authorities and financial regulators in seven large Latin American economies (LA-7) ${ }^{1}$ combined with publicly available data and information, this paper attempts to shed light on entry and contestability in retail banking services in the region, including access to the financial infrastructure - payments systems and credit reporting systems (CRSs) - while discussing the status of competition law enforcement and advocacy initiatives. Given limited antitrust enforcement and advocacy initiatives in the field of retail banking in LA-7, the objective of the paper is to advance knowledge on the status of competition in the retail banking segment while stimulating further country-product specific analysis.

\section{Using standard competition measures complemented by novel descriptive} and empirical evidence, this paper shows that competition in retail banking markets in LA-7 economies may be limited. Country-sector-level evidence points to high and growing market concentration and inadequate contestability. However, aggregate indicators may not necessarily reflect competitive dynamics at the product level, which is where markets are actually contested. Financial institutions' behavior may differ based on the product market they are competing in, with potentially different outcomes. To complement aggregate indicators, this paper uses a unique dataset on bank-level contractual interest rates to provide novel evidence on the link between bank market shares and pricing power for a sample of retail banking products in five large Latin American economies $(\mathrm{LA}-5)^{2}$ for which data are available.

\footnotetext{
Argentina, Brazil, Chile, Colombia, Mexico, Peru and Uruguay.
}

2 Brazil, Chile, Colombia, Mexico and Peru. 
Descriptive and empirical evidence suggests that higher bank market shares are correlated with less competitive pricing in both retail deposit and lending products, with the exception of the mortgage market, where the widespread practice to subsidize interest rates and/or re-mortgage and securitize loans may contaminate the relationship between market structure and pricing power. More research at the country-product level is needed to corroborate our findings and disentangle the complex relationship between market structure and market power.

\section{Network analysis focusing on payments systems} and CRSs confirms the presence of competition issues in the retail banking sector in LA-7. In most LA-7 countries, competition authorities and financial sector authorities have taken a more proactive approach to regulating payments markets to promote competition, but exclusionary practices and other anti-competition practices enabled by vertical integration still pose a significant challenge across the region. In many cases across LA-7 countries, participants of payments markets have created vertical structures that allow them to capture payment-related revenue in detriment of competition and development of the payments market.

\section{The authorities should assess costs of participa-} tion in the payments infrastructure and determine whether such costs are justified and proportional to the risks that each participant pose. Beyond participation and access fees, 'sunk' costs such as technological and operational infrastructure represent costs that must be covered by participants, and hence could constrain their possibilities of participating in a payments infrastructure. The authorities could put in place mechanisms to quantify the total cost of participation for each payments infrastructure and conduct audits to review if the technological, operational and business requirements are coherent with the level of risks each participant poses to the system. Adoption of international practices such as caps on fees and prices must be done after carefully reviewing the impact on local markets. As caps on fees are among the most used mechanisms to promote competition in payments markets it is important that the authorities are able to assess if the transmission mechanism to end-users would be effective or if the cap would be only captured by intermediaries and indirectly increase costs for end-users.

Impact analysis is essential to assess the consequences of policies to promote competition in the payments infrastructure market. The enactment of regulatory actions to promote competition should go together with an analysis of the effects of such actions, which requires designing specific metrics that can inform policymakers on the impact of the reforms. Participants' cost metrics are useful for this purpose, as these costs reflect business developments resulting from the entry of new players and platforms and increased usage of payment instruments. However, such metrics pose a challenge as the authorities must be able to gather granular information to assess each of the fees' components. This type of analysis would allow authorities to isolate the actual cost of providing a service and the profitability of the service and assess: (i) how these elements vary under changing market structures such as the emergence of new payments platforms, and (ii) if their levels are set to a level as to exclude participants from using a specific infrastructure. Also, as the payments market evolves, the authorities would need to periodically review the effects of changing market structures to ensure that previous policy actions still have the intended effect on competition. The authorities must develop enough institutional capacity to be able to conduct these assessments regularly and to modify the analytical framework to adapt it to new developments.

\section{The authorities could extend competition analysis to different types of payments instruments and the infrastructures that enable them. As new payment instruments such as credit transfers become more utilized at the checkout points, it is important to assess competition not only within the market of a specific payment instrument but across different payment instruments. Incumbents may have incentives to advance the adoption of a payment instrument. However, the authorities must ensure that incumbents do not engage in anti-competition practices to favor usage of a specific payment instrument.}

A properly designed GRS oversight framework could address market failures related to information 
asymmetries that impede competitive credit allocation. Efficient CRSs that collect comprehensive data from all relevant credit sources in the market and develop products and services that meet user needs with clear and fair rules regarding access can contribute to competitive credit markets. Data fragmentation between different yet disconnected CRS providers as well as lack of on-time payment information collected and shared on a systematic basis are the two main CRS failures that affect competitive credit allocation. Others include lack of access to tailored products based on information available or weak artificial intelligence tools developed by CRS providers. When availed with sufficient powers and responsibilities in the CRS market, the authorities could monitor the impact of such developments and take action to address them. For an oversight framework to be well-designed, the authorities would need to (i) define policy objectives, (ii) allocate sufficient resources, (iii) attribute formal mandates to the lead authority, and (iv) include all the relevant participants in the GRSs.

Competition authorities and financial sector authorities could start working together to understand the potential impact of large technology firms or "Big Techs" in the provision of financial services. Given their dominant position in the relevant markets as e-commerce platforms or data engines, these companies gather large amount of consumer data that enables them to offer financial products and services to consumers. While this trend holds the promise of benefiting consumers and enhancing financial inclusion, it might also come with unintended negative consequences for the credit markets, which warrants scrutiny. Regulatory authorities need to ensure a level playing field between Big Techs and banks, taking into account their customer base and access to information, and the possible range of business models. A balance between financial stability, competition and ultimately financial consumer protection, including data protection, might be necessary. The use of alternative data for creditworthiness evaluation has become a key aspect to further enable access to credit to those with thin files or no credit history. However, Big Techs tend to gather a large stock of data as a by-product of their main business, which is then utilized as input to offer wider services including financial services (for example, payments, lending, insurance and money management). For these reasons they have the potential to become dominant players through the advantages afforded by data gathering and comprehensive approach to provision of services.

Banking regulators should have mechanisms to ensure that past and future regulatory interventions do not unnecessarily or disproportionally limit competition in the market. Most Latin American banking regulators recognize competition as a regulatory principle in the law that defines their mandate. However, in practice, few systematic efforts have been made in the region to assess the impact on competition of regulation currently in force. Also, regulators generally lack instruments or mechanisms to ensure that the competition impact of proposed regulations or actions could render principles unenforceable in practice. Agencies can both conduct a comprehensive ex post assessment of current provisions affecting entry and conduct, and introduce various forms of ex ante protocols to assess competition impact of regulation, either independently or as part of general regulatory impact assessment. Under the premise that competition and financial stability can co-exist, and that pro-competition consideration must be adapted to the specific objective of each specific intervention, the objective of ex ante and ex post assessments would be to identify competition impacts and determine if alternatives exists that could preserve the prudential policy objective while minimizing competition restrictions. Regulators could engage with competition authorities to design protocols for the assessment, which could include instances of cooperation. This could guarantee that regulators promote an open and competitive banking sector going forward as part of the development of their pro-competition mandate.

In the Covid-19 crisis response and recovery, a competitive banking sector will be essential for Latin American economies and competition authorities' efforts should be pivoted towards enforcement and advocacy in the sector. Competition authorities must ensure a clear strategic plan to prioritize enforcement and advocacy in the banking sector. Latin American authorities 
are well equipped to investigate anticompetitive practices, prepare market studies and engage with other authorities to push for a more competitive banking sector. Efforts should be increased to apply to the banking sector instruments that have been successful in other sectors (for example, leniency programs). Rich international experience could be leveraged through international cooperation agreements in order to help develop more proactive investigative tools that are critical for successful prosecution. Where present, it is of the utmost importance that competition authorities advocate to eliminate exclusions from antitrust scrutiny in the banking sector. Advocacy is also of renewed importance to tackle government interventions to address the Covid-19 crisis, in particular in the banking sector, where mechanisms to include competition considerations must be introduced for the design and implementation of financial support to the banking sector. Replication in other Latin American countries of the 2014 Mexican systematic initiative to promote competition in the banking sector is highly desirable.

Effective and timely promotion and protection of competition in the banking sector requires cooperation mechanism between banking regulators and competition authorities. Since authority in the field of competition policy in banking services is allocated under a shared jurisdiction model in Latin America, a cooperation mechanism becomes a necessity. Numerous examples have been provided but specific mechanisms must be adapted to national legislation and institutions. Mechanisms may be formal or informal and where legislation is silent, interinstitutional agreements could be key to enabling cooperation. International staples of collaboration include opinion-giving on regulations, guidelines or case outcomes; information exchange and joint design of remedies; intervention in parallel procedures; joint investigation; or permanent task forces or working groups. Specific recommendations include developing legal mandates for collaboration as in Argentina or leveraging past or present joint initiatives to pursue further collaboration between agencies (for example, following the Peruvian payments systems market study with a study on retail banking).

As the Covid-19 crisis is likely to cause an increase in the number of national and international mergers in the banking sector, competition authorities and banking regulators need to be prepared for effective enforcement in such a scenario. Competition authorities should be involved in the clearance of mergers in the banking sector. While prevention of systemic bank failures will be prioritized, remedies can still minimize harm to competition. Thus, powers to impose remedies must be expanded when needed, including through joint design or monitoring with the banking regulator. Criteria needs to be developed to evaluate the failing firm defense, which could leverage international experience on the matter. Clear standards aligned with best practices are needed either in implementing regulations or guidelines. More importantly, where legislation does not predetermine coordination mechanisms, formal predetermined procedures for clearing the merger by multiple agencies should be laid out to give greater predictability. Authorities will need to adapt to rapid assessment while preserving a rigorous technical analysis. Specific recommendations include implementing regulation for merger review pending in Peru, and lifting the exclusion of conglomerate mergers involving financial institutions from review by the Colombian competition authority.

\section{Protecting competition in the banking sector requires an independent competition authority with sufficient tools to ensure an effective enforcement.}

Effective implementation of competition policy enforcement requires, among others, an adequate institutional structure and availability of technical and financial resources, and specific implementing rules, guidelines, capacities and skills to effectively prevent, investigate and prosecute anticompetitive practices and assess mergers. Of key importance in the operational framework of the competition authority is guaranteeing institutional independence, particularly in the budgetary and administrative areas. Adequate implementation of regulations, guidelines and case handling capabilities are also important. In particular, effective anticartel enforcement requires the rationalization of the use of exemptions, measures to reduce incentives to join and increase incentives to deviate from a cartel agreements (for example, leniency, whistleblowers, dawn raids, data processing), improvements in the fining system to increase deterrence, and prioritization of case work to prevent the most harmful practices. The prosecution of abuse of dominance cases also relies on the ability 
to obtain qualitative and quantitative empirical evidence and to analyze economic data. Specific recommendations include completing the setup of the competition authority (Argentina), finalizing or developing a targeted outreach of leniency in the banking sector (Argentina, Brazil, Colombia, Mexico, Peru) and introducing IT forensic capabilities (Uruguay and Argentina) or dawn raid powers (Uruguay).

\section{KEY RECOMMENDATIONS}

\section{Recommendation}

Measure costs of participation and review if such costs are justified and proportional to the risk that each participant poses to the payments infrastructure.

Regularly reassess the competition conditions in the payments infrastructures market, and the impact of policies to promote competition.

\section{Extend competition analysis to competition between different types of} payment instruments and the infrastructures that enable them.

Design a proper oversight function that takes into consideration market failures that affect competitive credit allocation.

Analyze the potential impact of informational advantages of Big Techs when also providing financial services.

Develop an ex ante protocol to assess competition impact of prudential regulation.

Conduct a comprehensive assessment of regulatory provisions for entry and operations by banking and other financial institutions with a view to recommend amendment of anti-competitive provisions.

Prioritize antitrust enforcement and advocacy initiatives in the banking sector.

Introduce coordination and cooperation mechanisms between competition authorities and banking regulators, either by legislation or bilateral agreements.

Introduce a framework and specific guidelines for the assessment of mergers in the banking sector, including expanding powers of competition authorities to review them and impose remedies, and criteria for review in a financial crisis context.

Reinforce the institutional independence of competition authorities and their tools to implement antitrust laws.
Topic

Payments

Payments

Payments

\begin{tabular}{lll} 
CRSs & Authorities \\
\hline CRSs & Financial Sector \\
& Authorities \\
\hline & Financial Sector \\
& Authorities
\end{tabular}

Sectoral regulation

Financial Sector

Authorities

Sectoral regulation

Financial Sector

Authorities

Antitrust enforcement

Competition Authorities

Antitrust enforcement,

Competition Author-

sectoral regulation

ities, Financial Sector Authorities

Antitrust enforcement, sectoral regulation

Competition Authorities, Financial Sector Authorities

Antitrust enforcement 



\section{INTRODUCTION}

Bank financial intermediation, that is channeling funds from units in surplus to units in deficit, plays a critical role in sustainable and inclusive growth. There is a considerable body of evidence showing that the extent to which an economy is making use of banking intermediation is not only associated with economic growth and broader access to financial services but it is also a causal factor in explaining overall economic performance (see, for example, Levine, 2005), poverty reduction (for example, Beck et al., 2007) and reduced inequality (for example, Demirgüç-Kunt and Levine, 2009). The costs associated with financial intermediation have an important bearing on the depth and breadth of the banking system. High costs of financial intermediation are associated with credit rationing and thus a lower level of credit channeled to borrowers (Stiglitz and Weiss, 1981). Countries with lower costs of financial intermediation experience higher levels of financial development and higher penetration in the use of financial services.

Despite positive advances in financial deepening and financial inclusion, costs of financial intermediation in Latin America remain among the highest in the world. Net interest spreads, that is the difference between lending rates and deposit rates - a widely used proxy for the costs of financial intermediationaveraged 7.4 percent during 1999-2018, a level significantly higher than what is observed in other regions except for Sub-Saharan Africa (Figure 1.1, Panel A). Moreover, while spreads have shown a downward trend in many regions, they have remained stubbornly stable in Latin America. Although the banking industry has benefited from significant technology adoption, which has translated into cost efficiency gains, these improvements have not been passed on as lower costs to the end users of financial services. At the same time, the cost of credit risk experienced a steady decline, implying that banks may have pocketed super-normal profits (Figure 1.1, Panel B).

Limited competition may be an important supply side determinant of high costs of financial intermediation in Latin America. There are several plausible reasons for why the provision of banking services in the region remains expensive. A history of macroeconomic and financial volatility is an important source of uncertainty that needs to be compensated for by charging higher spreads. Moreover, 


\section{FIGURE 1.1: COSTS OF FINANCIAL INTERMEDIATION IN LATIN AMERICA}

\section{PANELA}

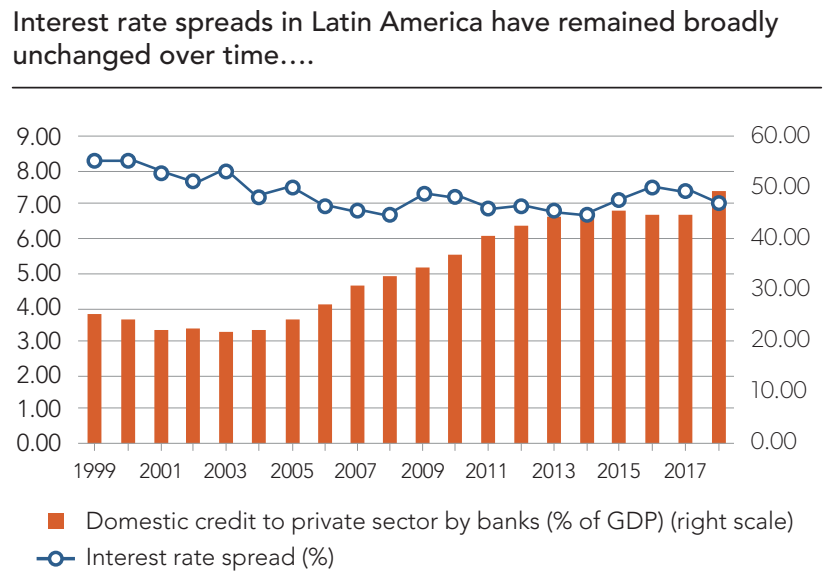

PANEL B

Technology adoption has increased....

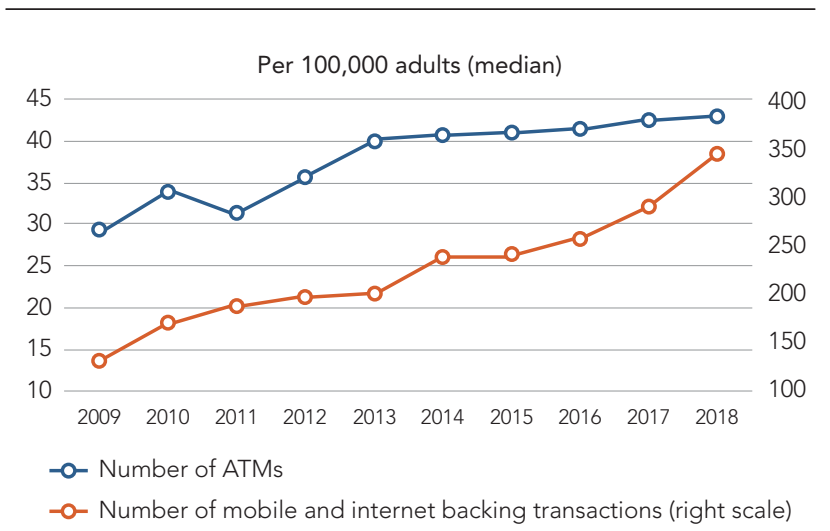

Source: World Development Indicators; FinStats; Financial Access Survey

residual gaps in the legal and contractual environment translate into a premium that financial institutions demand on intermediation activities. Finally, specific features of financial institutions such as leverage, the scale of operations, and risk preferences all affect the final costs of financial intermediation. An additional and potentially important supply-side explanation of low financial intermediation efficiency in Latin America is limited competition.

\section{Competition matters for the efficiency of financial} intermediation. As in other industries, increased competition in the banking sector leads to lower costs and enhanced efficiency of production of financial services, greater product innovation, and improved quality. Though financial services have some special properties, the channels are similar to other industries. Relaxing entry barriers leads
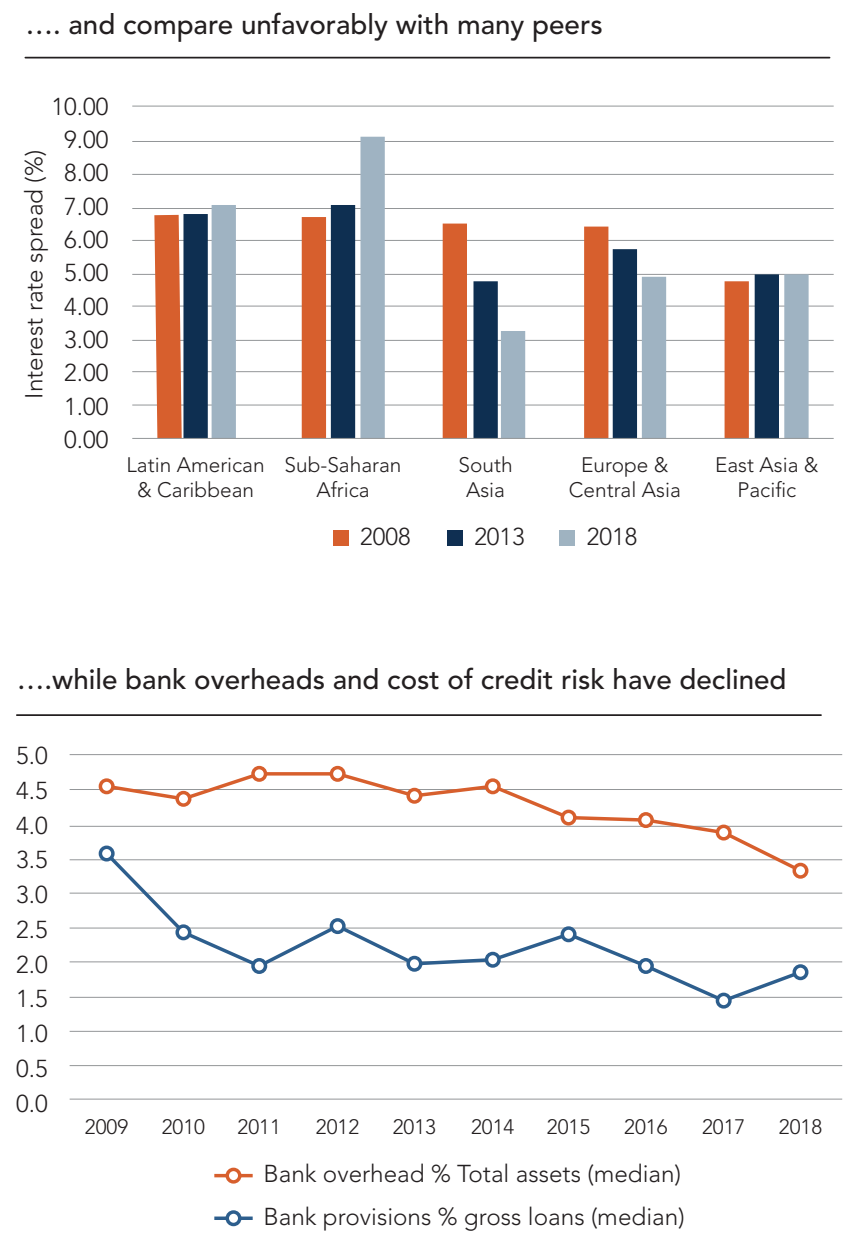

to a decline in equilibrium loan rates and an increase in deposit interest rates (Besanko and Thakor, 1992). In turn, by lowering the costs of financial intermediation, and thus lowering the cost of capital for non-financial firms, more competitive banking systems lead to higher output growth rates (World Bank, 2013). However, excessive competition may have important implications for financial stability, as it has long been recognized by the literature and the conduct of prudential policy. ${ }^{3}$ Therefore, competition should be considered as part of a broader set of policy objectives - including financial intermediation efficiency, access to financial services, and, crucially, systemic financial sector stability.

3 See, for example, World Bank (2016a), for a review of the literature. 
Restrictions to competition in the banking sector can stem from both private practices and government interventions. The interaction of market players' behavior and government actions impacts the level of competition in a given market. The objective of competition analysis is to align government interventions with competition principles, considering inherent market features to give firms the incentives they need to strive for efficiency and, ultimately, help boost overall welfare. Governments can influence market outcomes either through direct participation (as a buyer or supplier of goods and services) or through indirect participation (for example, through regulation, taxation, subsidies, or other policy and regulatory instruments). Both types of interventions affect competition dynamics.
This paper is a fist attempt at analyzing competition in the retail banking markets in Latin America. The analytical framework adopted consists of three core elements: (i) market features, including market structure, vertical integration and direct government participation in the market; (ii) government interventions including sectoral and economy-wide policies, regulations and their implementation that affect the functioning of the market; and (iii) market outcomes encompassing anticompetitive behavior (for example, abuse of dominance, cartels), concentration and market entry, among others (Figure 1.2). This framework not only facilitates the assessment of market dynamics, but also the identification and prioritization of potential reform initiatives to foster entry and investment while ensuring a level playing field.

\section{FIGURE 1.2: ANALYTICAL FRAMEWORK FOR ASSESSING COMPETITION}

\section{MARKET CHARACTERISTICS}

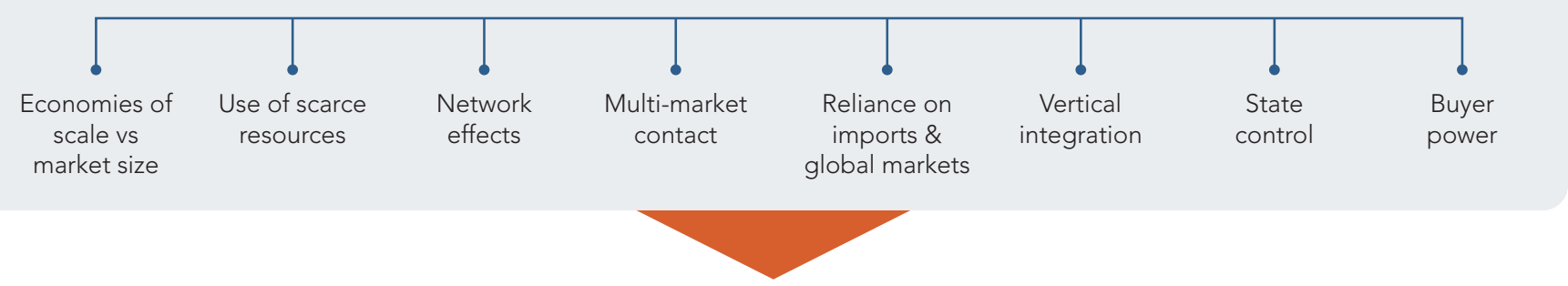

\section{GOVERNMENT INTERVENTIONS THAT CREATE OBSTACLES TO COMPETITION}

Rules that limit entry or reinforce dominance
Rules that are conducive to collusion or reduce firms' choice of strategic variables
Rules/actions that discriminate, distort the level playing field and protect certain firms

\section{EFFECTIVNESS OF COMPETITION LAW ENFORCEMENT E.G. CARTELS, ABUSE OF DOMINANCE}

\section{OUTCOMES}

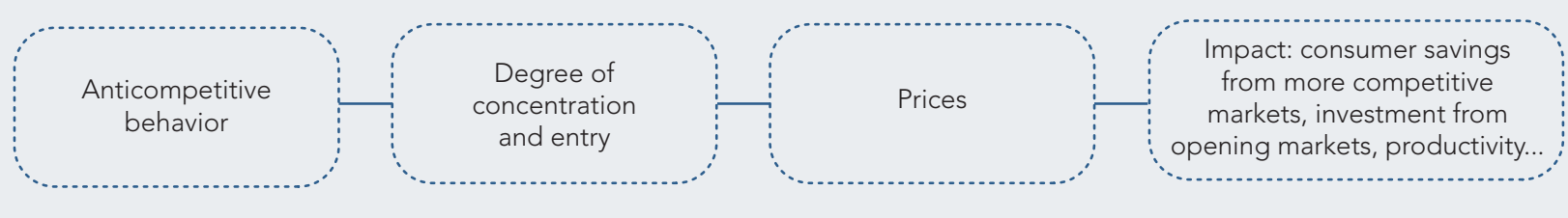


The assessment considers a sector background to identify common policy objectives linked to it as well as development objectives. This background is key to identify constraints and understand the rationale for government interventions including what are the main constraints in achieving sectoral goals. This paper recognizes that within the banking sector each product fulfills a specific customer need and therefore the relevant universe of analysis or, in other words, the relevant market for competition analysis is narrower than the overall banking sector. Competition takes place at the financial product level and in some cases the market for those products can be local or national. While this paper cannot determine a specific relevant market in the antitrust sense for each piece of analysis, it provides a major step ahead in providing the first regionally comparable analysis of product-specific competition indicators.

The analysis in this paper sets off with an assessment of market outcomes, including market structure and pricing power. Some degree of concentration and market power can occur naturally due to the features of the market such as economies of scale. This does not necessarily imply a lack of competition as long as that power is not abused and the market remains contestable. Therefore, in order to assess the degree of competition, one measure alone is not sufficient. This paper therefore combines structural indicators as well as those associated with pricing power. Determining the existence of a specific anti-competitive practices such as abuse of dominance requires an investigation using private and often confidential information. This is beyond the scope of this paper.

In a second step this paper deals with the implications of key market features, namely network effects. Financial services provision involves the use of a great number of networks, such as payments, distribution and information systems. This means that barriers to entry can arise due to a lack of access for some financial services providers to essential facilities or services. The description of market characteristics seeks to identify inherent features of the market that shape its dynamics. This is key for the identification of natural and strategic barriers to entry, or other relevant factors. Generally, such an analysis includes identifying the dynamic market structure (for example, number of players and, entry and exit), demand and supply characteristics (for example, economies of scale and scope, capital investment, product homogeneity), and other features that may generate market failures (for example, information asymmetries, externalities). In this particular case, the focus is on network features, specifically payment and information networks, and the implications of effects of vertical integration and economies of scale on the overall level playing field.

This paper discusses government options to address and mitigate natural market features in these network segments. In particular, it assesses those actions that constraint the ability of market players to enter, compete and grow. Market failures can cause sub-optimal market outcomes and government intervention should be designed to address them while minimizing competition distortions. Under the proposed framework, the assessment identifies market failures and government actions/interventions to address them (or not), and their effects on competition to determine if there is an unnecessary restriction. Sub optimal outcomes can also be caused by a lack of a justified government intervention to address a market failure that limits competition. Similarly, anticompetitive effects can be caused by rules or actions from private actors (for example, co-regulation or self-regulation schemes). Rules may reinforce dominance or limit entry, facilitate collusive practices or increase costs to compete or even discriminate and protect vested interests.

This paper finally assesses the tools that the government has to address any uncompetitive outcomes that can arise, including as a result of the interaction between market features and other government interventions. The paper reviews the laws and enforcement capabilities in place to address anti-competitive concentration ex ante as well as anti-competitive behavior ex post. Competition in the banking sector is mostly shaped by interventions (for example, regulations, actions or omissions) by the banking regulator and/or the competition authority (or even the lack thereof). Each agency has a toolkit to promote and protect competition in the banking sector that depends not only on the scope but also on the interaction with each other's mandate and 
tools. A cross sectoral competition law that covers the banking sector aims at controlling firm behavior ex post and is generally enforced by the competition authority. Concurrent or shared jurisdiction may also be possible where the banking regulator also enforces competition law or participates in specifics aspects, commonly merger review. Banking regulation, which is usually exclusively in the hands a banking regulator, may supersede competition law (i.e. preemption of one legal instrument over another).
Thus, limits of a firm's behavior can be determined ex ante and any conduct enabled by sectoral regulation is safe from antitrust scrutiny. However, sectoral regulation may mandate that sectoral regulation must be designed under competition principles. In the same vein, competition law may enable the competition authority to advocate for competition in the banking sector, which could include recommending reform of sector specific regulation.

Framework to understand key questions on the intersection and interplay between competition and regulatory framework and institutional set-up

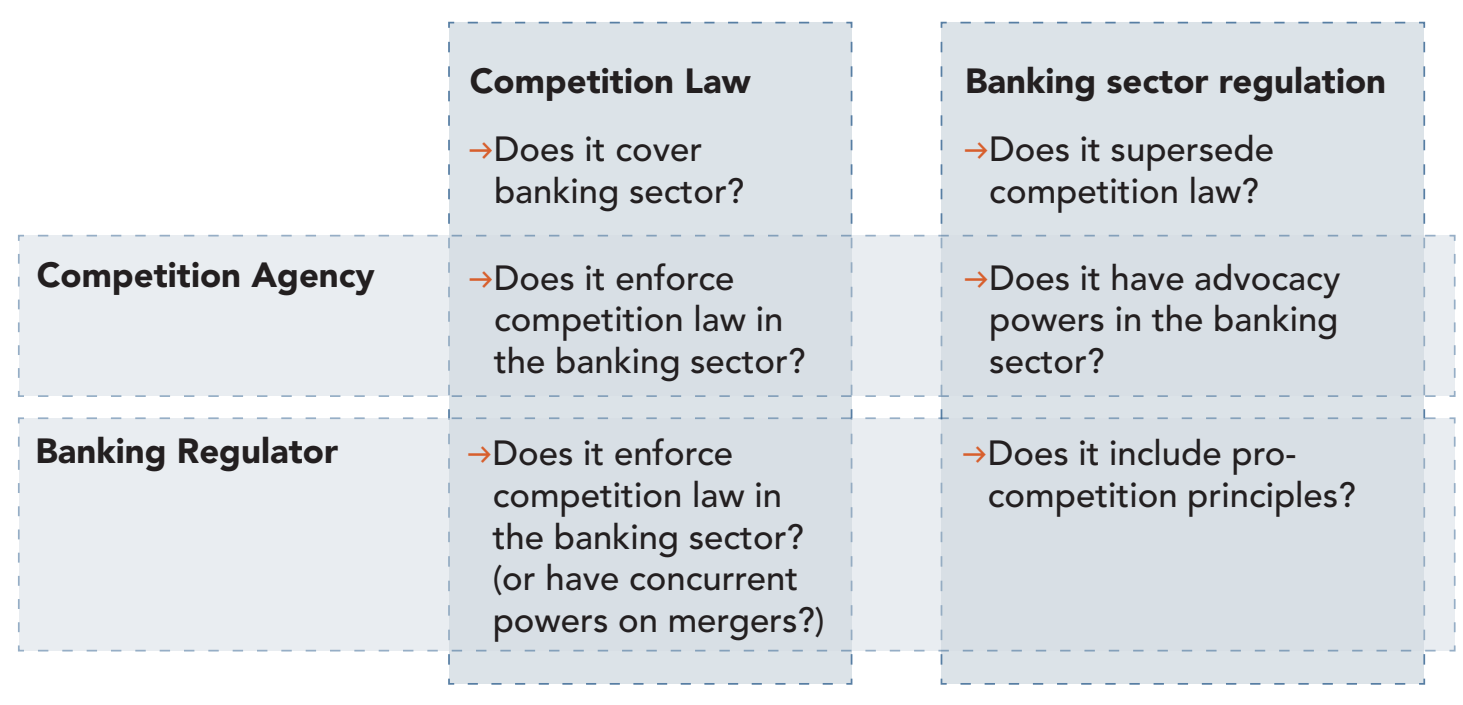





\section{CHAPTER 1:}

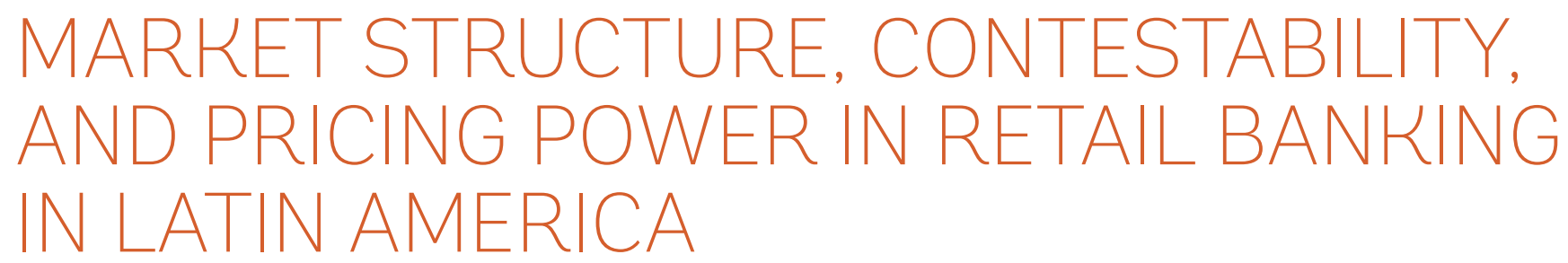

This chapter analyzes entry, exit, and contestability in the banking market of seven large Latin American countries (LA-7). ${ }^{4}$ Using standard industrial organization indicators, it provides evidence that competition in retail banking markets in LA-7 economies may be restricted. Evidence points to high and growing market concentration and limited contestability, though these indicators may not necessarily reflect competitive dynamics at the product level, which is where markets are actually defined. Financial institutions' behavior may differ based on the product market they are competing in, with potentially different outcomes. For this reason, using a unique dataset on bank-level contractual interest rates, this chapter also presents descriptive and empirical evidence on the link between bank market shares and pricing power for a sample of retail banking products in five large Latin American economies (LA-5) for which data are available. ${ }^{5}$ It shows that higher bank market shares are associated with less competitive pricing in both retail deposit and lending products, except in the mortgage market, where the common practice to subsidize interest rates and/or to remortgage and securitize may contaminate the relationship between market structure and pricing.

\footnotetext{
4 Argentina, Brazil, Chile, Colombia, Mexico, Peru, and Uruguay.

5 Brazil, Chile, Colombia, Mexico, and Peru.
} 


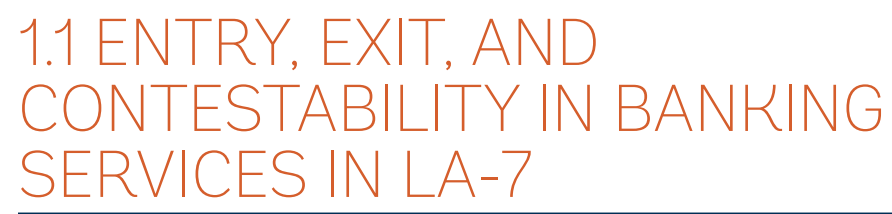

In this section, we analyze market structure, contestability, and market power in the banking market of LA-7 countries. Following common approaches to measure competition in the financial sector, the discussion considers factors such as the number of banks and market concentration to infer competitive dynamics in the banking sector in LA-7. These indicators, which rely on the structure-conduct-performance paradigm, imply that there is a relationship between the structure of the market, the behavior of banks, and the efficiency of financial intermediation. However, these measures do not directly gauge banks' behavior. Structural indicators are complemented by regulatory indicators to gauge contestability. Following Barth, Caprio, and Levine (2013), we build indexes that account for entry into banking requirements, limitations on foreign bank entry and ownership, and an indication of churning accounted for through the percentage of entry applications denied. ${ }^{6}$ We finally provide indication of the extent of bank pricing behavior and market power resorting to more formal competition measures such as the Lerner index.

There has been a generalized reduction in the number of banks across LA-7 though with some country variations. There may be different explanations for this trend, including the GFG that may have spurred consolidation, but accounting for entry and exit, the number of commercial banks in LA-7 contracted by 8 percent during 2004-2018, from 327 to 301 . There are some notable exceptions, however. For example, Mexico increased the number of commercial banks by two-thirds during the period, from 30 to 50 . The reduction in the number of banks is more remarkable when scaled by the adult population, which increased by a quarter in LA-7 during 2004-2018. This is most evident in Chile, where

6 To measure properly churning, entry and exit into the banking market should be accounted for. Both pieces of information are available through the Bank Regulation and Supervision Survey (BRSS). Indeed, exit should encompass not only liquidation but also bankruptcy, merger, and acquisitions. Because these occurrences may be recorded at a specific point in time but affect several years, we decided to focus just on entry. the absolute number of banks reduced to 19 from 27, but the number of banks per million adults shrank to 2.3 from 1.3 during 2004-2018 (Figure 2, Panel A).

Banking market concentration has trended upward, proportionally more than in other regions. The reduction in the number of banks was mostly the result of opportunistic mergers and acquisitions, especially following the GFC, when many international banks left the region as a part of their downsizing and restructuring with their subsidiaries being taken over by large incumbents, which consolidated and strengthened their position. As a result, banking systems in LA-7 have become increasingly concentrated, with the median share of total assets held by the three largest banks reaching 65.2 percent in 2018 compared with 50.5 percent 10 years earlier. Consolidation occurred in other regions as well, with the exception of South Asia, where concentration decreased in the decade 2009-2018. However, the increase in the median concentration levels in LA-7 has been noticeably higher than the one observed in other groupings, though starting from a lower base in some cases (Figure 2, Panel B).

\section{The stringency of requirements to obtain a} banking license has increased over time. Strict requirements may increase barriers to entry into the market because of the increase in the 'sunk' costs of participation and of compliance with a number of legal requisites. For example, although entry requirements ensure that a bank is adequately capitalized to start a business, they may also prevent competitors from entering the market, raising the initial costs to start the business. Barth, Caprio, and Levine (2013) propose an index to capture the number of legal submissions to obtain a banking license, such as the background of future managers and the intended market differentiation of the new bank. Using data from the four latest BRSSs, ${ }^{7}$ we compare the index for LA-7 countries over time. As shown in Figure 3, Panel A, over time we observe an increase in the stringency of the requirements as much more information and more legal submissions are requested in the process of obtaining a banking license. Moreover, the number of legal requisites has also increased over time

\footnotetext{
We use the most recent four BRSS waves. The second update of the database was released in 2003, the third in 2007, the fourth in 2012, and the latest was completed in 2019.
} 


\section{PANELA}

The number of banks has decreased in absolute number...

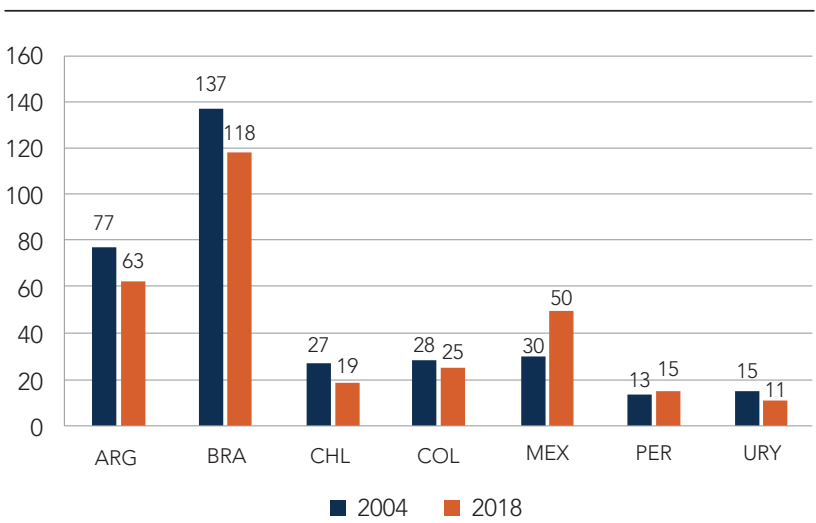

\section{PANEL B}

The share of the market held by the three largest banks has trended upward....

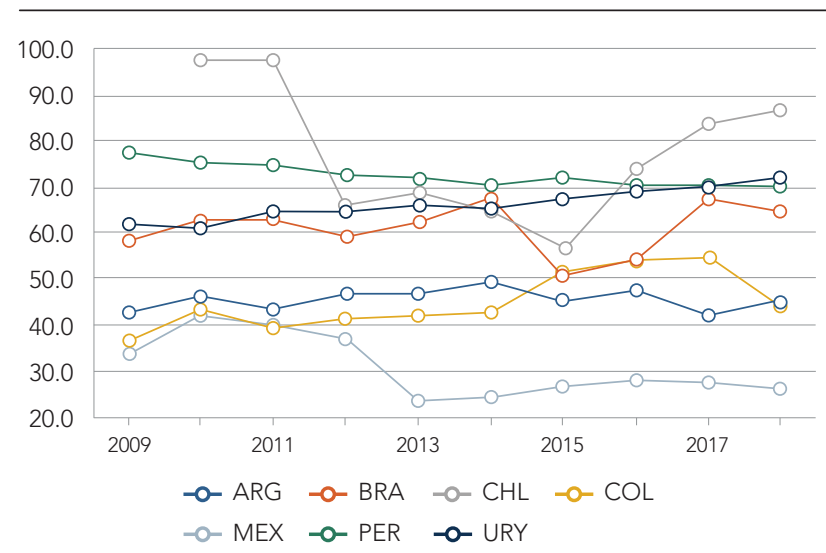

Source: FinStats; Financial Access Survey.

to include, for instance, the background information on the potential shareholders and the structure of the board.

\section{Foreign banks are in general allowed to operate} in the domestic banking markets in LA-7. Foreign bank competition may benefit contestability and efficiency in the banking market. Although there are risks and benefits associated with competition in the domestic market by foreign banks, ${ }^{8}$ the presence of foreign competitors with different technologies may spur competition and increase efficiency of the incumbents. Limiting foreign bank entry by hindering the possibility to buy a domestic bank or

8 For an in-depth discussion of the benefits and limitations of international banking, see World Bank (2018).

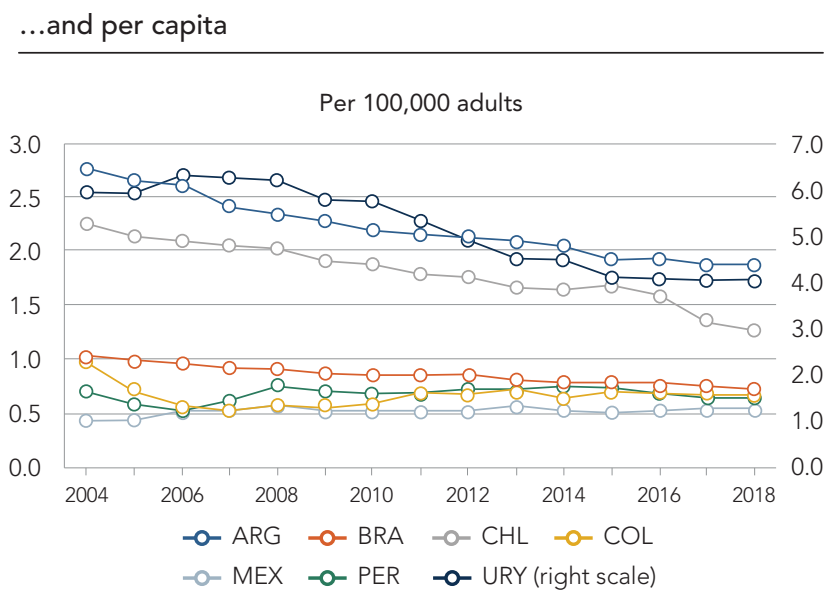

...proportionally more than in other regions

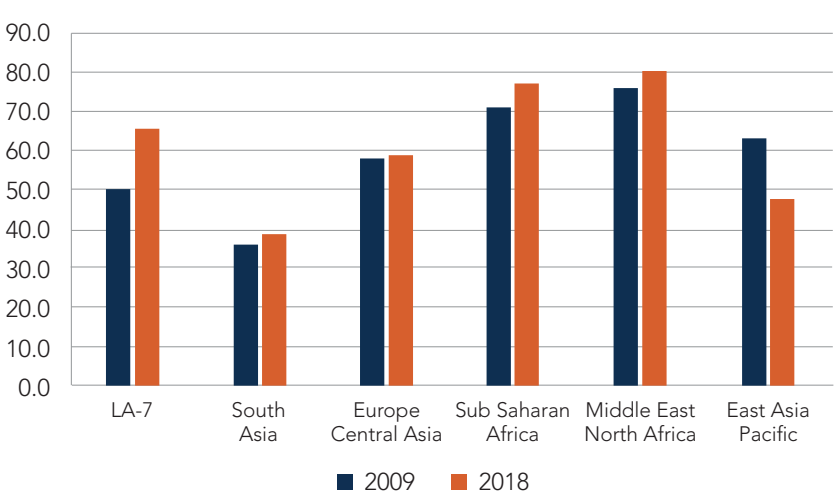

opening branches and subsidiaries may therefore clog this channel. As reported in Figure 3, Panel A, the latest data show that bar Mexico all LA-7 countries allow foreign banks to operate in the domestic banking market through acquisition or the ownership of a subsidiary or a branch.

Some LA-7 countries have seen a sustained number of applications, denoting healthy competitive pressures in the banking market. Competitors may be disincentivized to submit applications for entering the banking market. Incumbents would then be less affected by the threat of market entry in presence of significant market power. A relative comparison is offered by the number of total applications received (as defined above) 
normalized by the total population. As reported in Figure 3, Panel B, Brazil and Peru witnessed an increase in the relative number of total applications received between BRSS rounds 2 and 5. In other countries, the relative number of applications has been low or decreased over time.
A relatively high number of applications have been denied in LA-7. Bank regulatory agencies may deny access into the banking market for a number of reasons, such as capital quality, reputation, and potential home-host issues that could affect effective supervision.

\section{FIGURE 3: REGULATORY INDICATORS OF CONTESTABILITY}

\section{PANELA}

Entry into banking has become more difficult ${ }^{\mathrm{a}} \ldots$.

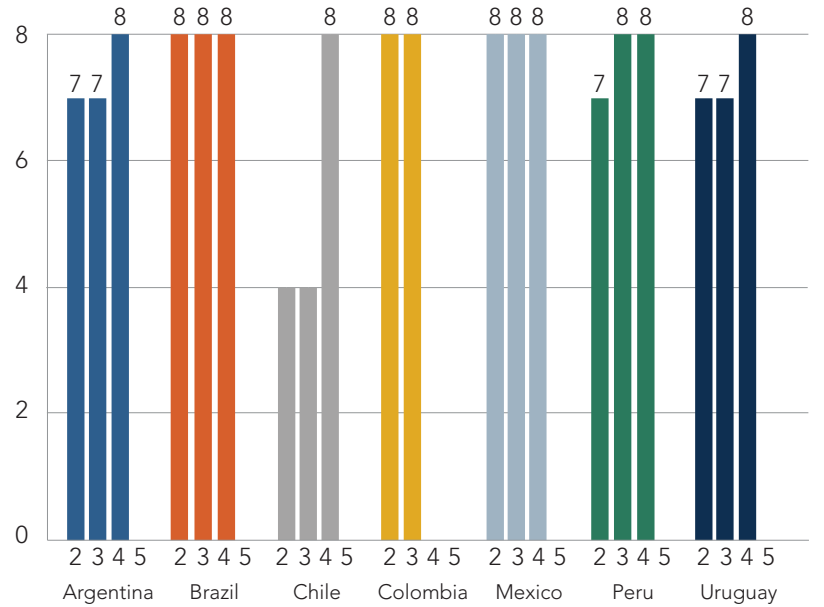

\section{PANEL B}

New applications have been submitted....

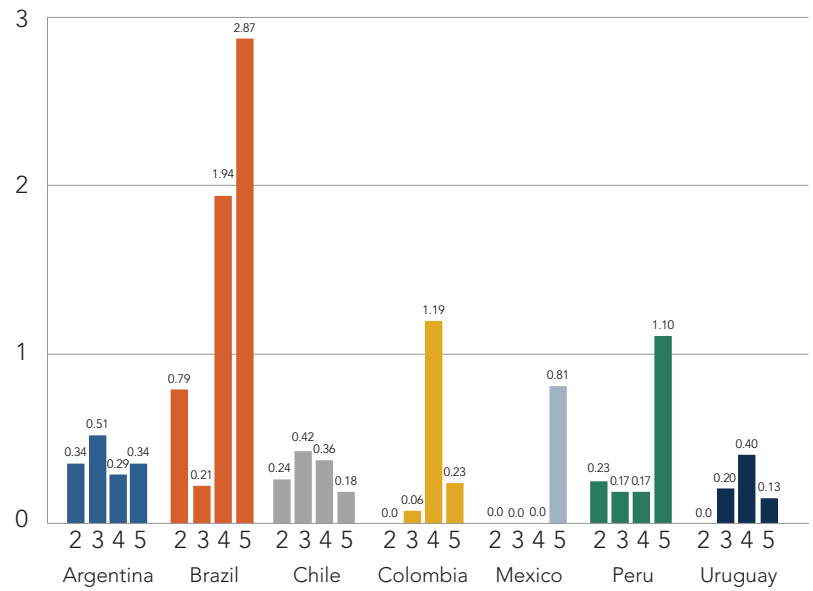

...though foreign entry is generally allowed ${ }^{\mathrm{b}}$

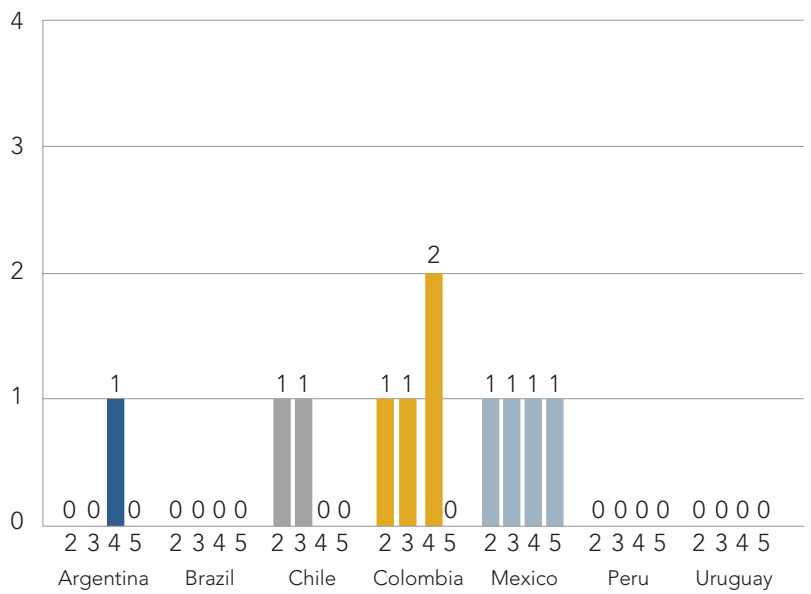

....but entry has been largely denied ${ }^{c}$

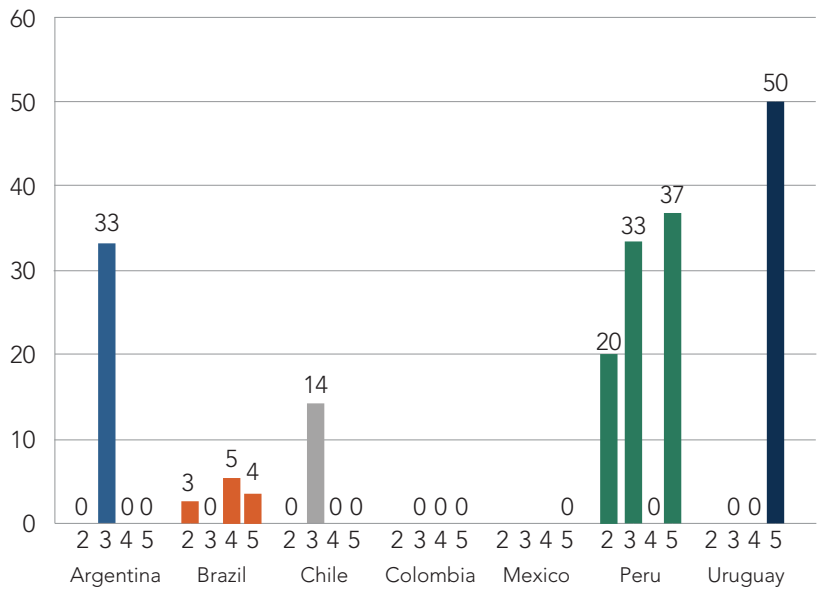

Source: BRSS, https://www.worldbank.org/en/research/brief/BRSS

Note: a. The index ranges between 0 and 8 . Higher values of the index denote greater stringency. Data are not available for Colombia for the fourth wave of the BRSS

b. Higher values of the index denote higher stringency. The index ranges between 0 and 4 .

c. Higher values of the index denote higher stringency. Reported the percentage of denied applications for commercial banking licenses from domestic entities, acquisition of a domestic bank, branch, or subsidiary from foreign banks. Data for wave 2 are not available for Argentina, Colombia, and Uruguay; for Mexico, data are not available for waves 2 through 4 . 
Figure 3, Panel B, reports the fraction of denied applications for domestic banking licenses and the number of denied applications by a foreign bank to enter through acquisition of a domestic bank or subsidiary or opening of a branch. Peru and Uruguay show an increase over time in the percentage of applications denied. The latest data show that Peru denied seven applications, six for commercial banking licenses from domestic entities and one from a foreign bank to enter through a new subsidiary. ${ }^{9}$ For the former group of applicants, the supervisory agency denied entry into banking because of capital amount and quality, incomplete applications, and noncompliance with 'fit and proper' criteria for potential shareholders, board members, and senior management. The foreign bank was denied entry into the Peruvian banking market because of a legal restriction related to the number of banks owned by a common shareholder. In Uruguay, two applications were received to enter into the banking market through acquisition of a domestic bank and through a new subsidiary. The latter application was denied on the ground that there were potential home-host issues that could affect effective supervision.

Banks in LA-7 may enjoy pricing power. One plausible explanation for the recent consolidation trend in the region is that it has been driven primarily by market power rather than by seeking efficiency gains. The possibility of increasing prices above competitive levels reflects market power. Market power is typically approximated using the price-to-cost margin, which is derived from the Lerner index. Figure 4 reports the development of the price-to-cost margin over time for LA-7 between 2005 and 2014 (latest data available). Overall, except for Brazil and Mexico, the pricing power of banks was higher in 2014 than it was at the end of 2005. This upward trend is more pronounced for Argentina, Colombia, and Peru.

Overall there is some preliminary evidence that LA-7 countries may suffer from a lack of contestability and competition in the banking market. Market concentration has trended upward while the number of legal submissions to obtain a banking license has increased over time, making it costlier to enter into the banking

9 In April 2020, the Peruvian authorities issued a banking license to Bank of China.

\section{FIGURE 4: LERNER INDEX (\%)}

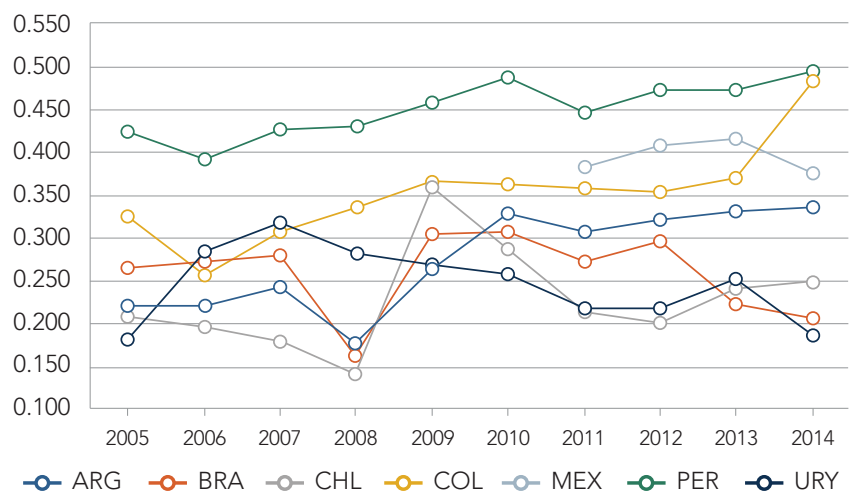

Source: Global Financial Development Database (GFDD), http://www.worldbank.org/ financialdevelopment.

Note: It provides a measure of the markup over marginal costs (price-to-cost margin). It is defined as the difference between output prices and marginal costs (relative to prices). Prices are calculated as total bank revenue over assets, whereas marginal costs are obtained from an estimated translog cost function. An increase in the Lerner index suggests that firms face lower levels of competition intensity.

market. Although in all LA-7 bar Mexico foreign banks can operate freely, there is an indication of limited contestability because of the relatively low number of successful new applications to operate a credit establishment combined with high market power. It is important to notice that these analyses present some limitations due to the construction of broad indexes and the level of aggregation of the data. The descriptive evidence presented in this section offers only a partial indication of the degree of competition and the conduct of the banks in the market. In the next section we attempt to overcome this issue and offer more details on market structure and competition in the retail banking market for specific deposit and lending products.

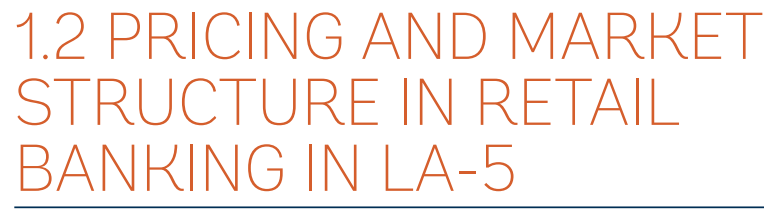

In this section, we summarize descriptive evidence on pricing power and degree of market competition in retail banking in LA-5. Information is provided using a unique dataset on contractual interest rates at the product level gathered through publicly available information. Detailed data were gathered through bank supervisory and central bank websites. Balance sheet, income statement, and product-level information were mapped to 
individual local bank identification numbers as assigned by their supervisor for continuity in the cases of ownership change. Though financial statements are standardized by the widespread use of International Financial Reporting Standards (IFRS), analysis at the product level is affected by differences in market features (for example, the use of inflation-indexed products in Chile or the widespread diffusion of variable rates in Brazil) and the fact that there is no common approach to the disclosure of individual banks' interest rates. In most cases, loans and deposit rates are contractual rates, that is, not computed ex post using income statement information. ${ }^{10}$ This provides the advantage of partly disentangling pricing power from the degree of efficiency of the individual institutions.

\section{Our detailed analysis of retail banking in LA-5} builds on information at the bank level, distinguishing among different financial products. We collect information on 200 banks in LA-5 over 10 years (see Figure 5 for a breakdown of the number of banks by country and year) representing all of the private commercial banks (local and foreign-owned banks) of those countries. ${ }^{11}$ The information covers some basic features of the banks (name, ownership, and if it is part of a conglomerate), total assets, some income statement items (for example, interest income and interest expenses), and, crucially, volumes and contractual rates (for example, rates advertised on products) for three retail credit segments - personal or uncollateralized loans, residential mortgages, and credit cards - and one retail deposit product - term deposits.

\section{The degree of cross-sectional variation in the rates charged on banking products varies across countries depending on the type of product. Within} a country, data show that the spread of the distribution varies over time, indicating that a bank's revenues and costs may change recurrently depending on certain factors such as the degree of market competition. In general, Colombia and Chile show the lowest variability in contractual rates (Figure 6). ${ }^{12}$

\section{FIGURE 5: NUMBER OF BANKS BY COUNTRY AND YEAR}

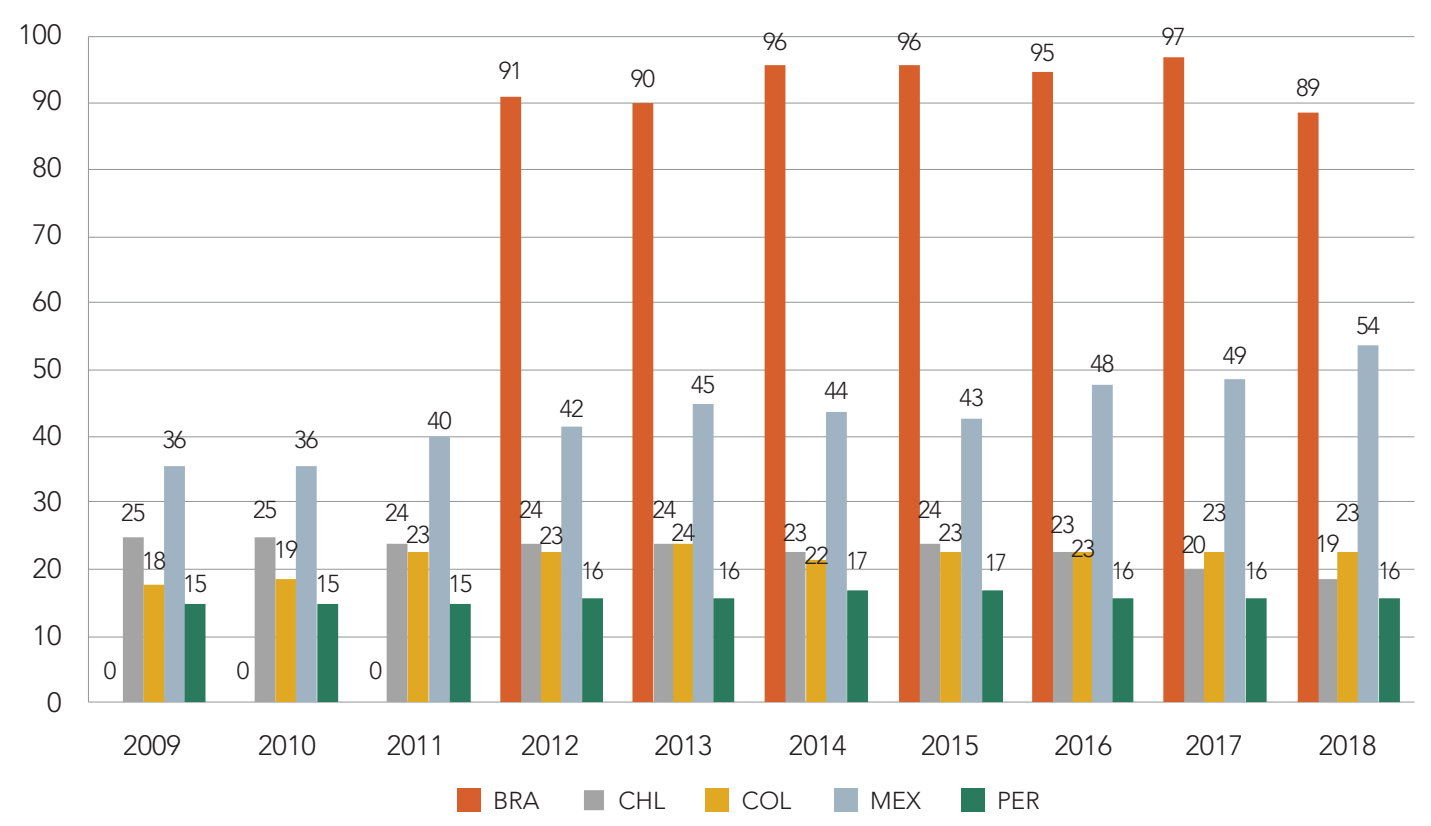

Note: This chart reports the number of banks in each country for which we have information in each year.

${ }_{10}$ Unfortunately, we were not able to collect bank-level contractual interest rates in Mexico, so our analysis relies on implicit interest rates from income statements. Moreover, Banco Central do Brasil only provides individual bank contractual rates for one-week windows, so we relied on sample averages for each year (covering at least 90 percent of the loan-providing institutions by each market segment volume).

\footnotetext{
11 In the cases of Brazil, Colombia, and Chile, state-owned commercial banks were also included in the sample.

12 Statements of low and high variability are supported by the analysis of the coefficient of variation, that is, the extent of variability of the distribution expressed as the ratio of its standard deviation to the mean.
} 
FIGURE 6: DISTRIBUTION OF THE CONTRACTUAL RATES BY COUNTRY

Rate on term deposits

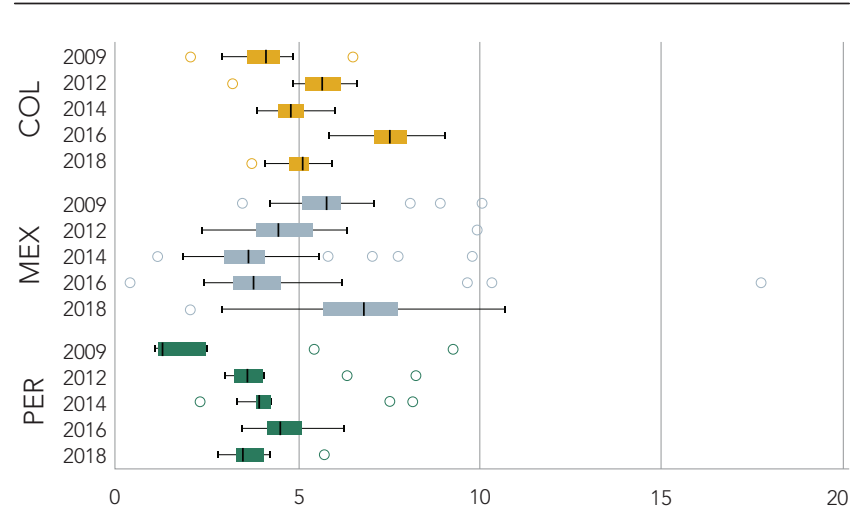

Rate on credit cards

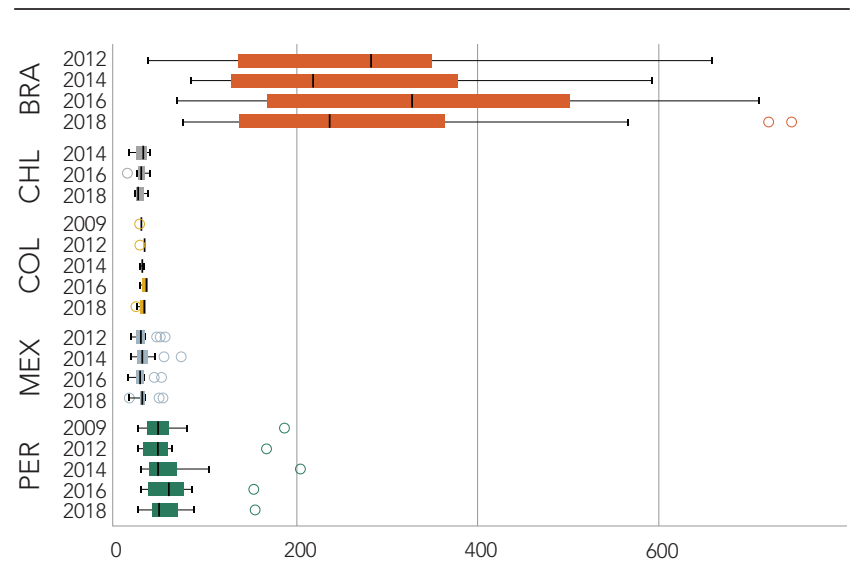

Rate on personal loans

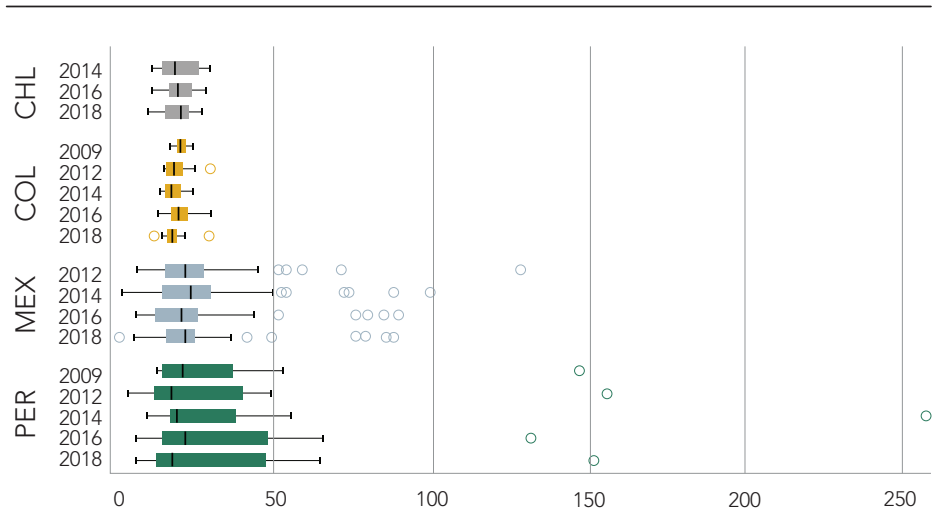

Rate on mortgages

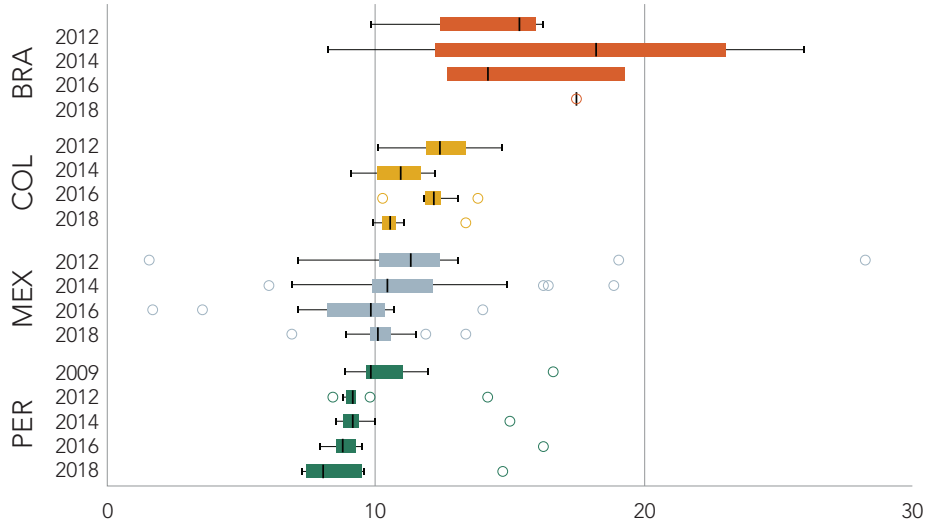

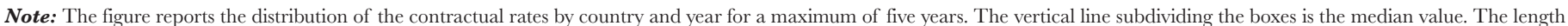

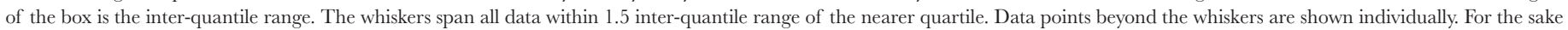
of representation, we just report a maximum of five years of data.

The variability in the term deposit rates is highest in Mexico, driven by the noticeable increase in the spread of the distribution in 2018. For 2018, Mexico also shows the highest median cost on term deposits and the wider range of the distribution, with banks paying from 1.9 percent to 10.7 percent (on an annual basis). The distribution of term deposits in Peru is instead characterized by few intermediaries that offer rates well above the median value. Data for Colombia show little variation.

The variability in the rates on personal loans is highest in Peru. Few credit institutions offer rates well above 50 percent (on an annual basis) both in Mexico and Peru. In both countries few intermediaries offer rates well above the median value. Mexico also shows the highest median value for 2018. Data for Chile and Colombia show little variation.
The variability in the rates on credit cards is highest in Peru with rates as high as $\mathbf{2 2 0}$ percent on an annual basis. Among the lending products analyzed in this section, credit cards are the most expensive and show the highest average annual rate. The distribution is also dispersed in the case of Brazil where rates over the period are on average around 280 percent on an annual basis. All countries have a median rate over the period above 25 percent (on an annual basis).

The variability in the rates on mortgages is highest in Brazil. Few credit institutions offer rates well above 10 percent (on an annual basis) both in Mexico and Peru. All countries have a median rate over the period above 9 percent (on an annual basis). Colombia has the tighter distribution though on levels mortgage rates are comparable 
to the other countries as for each year the median interest rate is above 10 percent (on an annual basis).

\section{The evolution over time of the median contractual} rates shows variability between loans and deposits. For Colombia, Mexico, and Peru, the contractual rate paid on term deposits was higher by the end of 2018 than it was in 2009. Recent trends are different though as in Mexico there has been a notable increase in the median contractual rate since 2015 whereas in Colombia and partially in Peru there has been a downward trend since 2016 (Figure 7).

The median rates on personal loans vary over time, with the greater variation recorded by Peru and Mexico. By the end of 2018, Mexico had the highest median value in personal loans at around 21 percent (on an annual basis), followed by Chile, Colombia, and Peru. Data are available for all countries since 2013. At that time, Peru had the highest value of the median rates on personal loans.

The median rates on credit cards vary most for Brazil. Brazil also has the highest absolute value of the median rates (on an annual basis) over the period. The other LA-5 countries show a smoother development over time. Among these countries, between 2013 and 2018, Chile was the only country showing a downward trend in the interest rates on credit cards for which the median value was significantly lower in 2018 than in 2013 according a rank sum test.

\section{FIGURE 7: EVOLUTION OVER TIME OF THE MEDIAN CONTRACTUAL RATES BY COUNTRY}
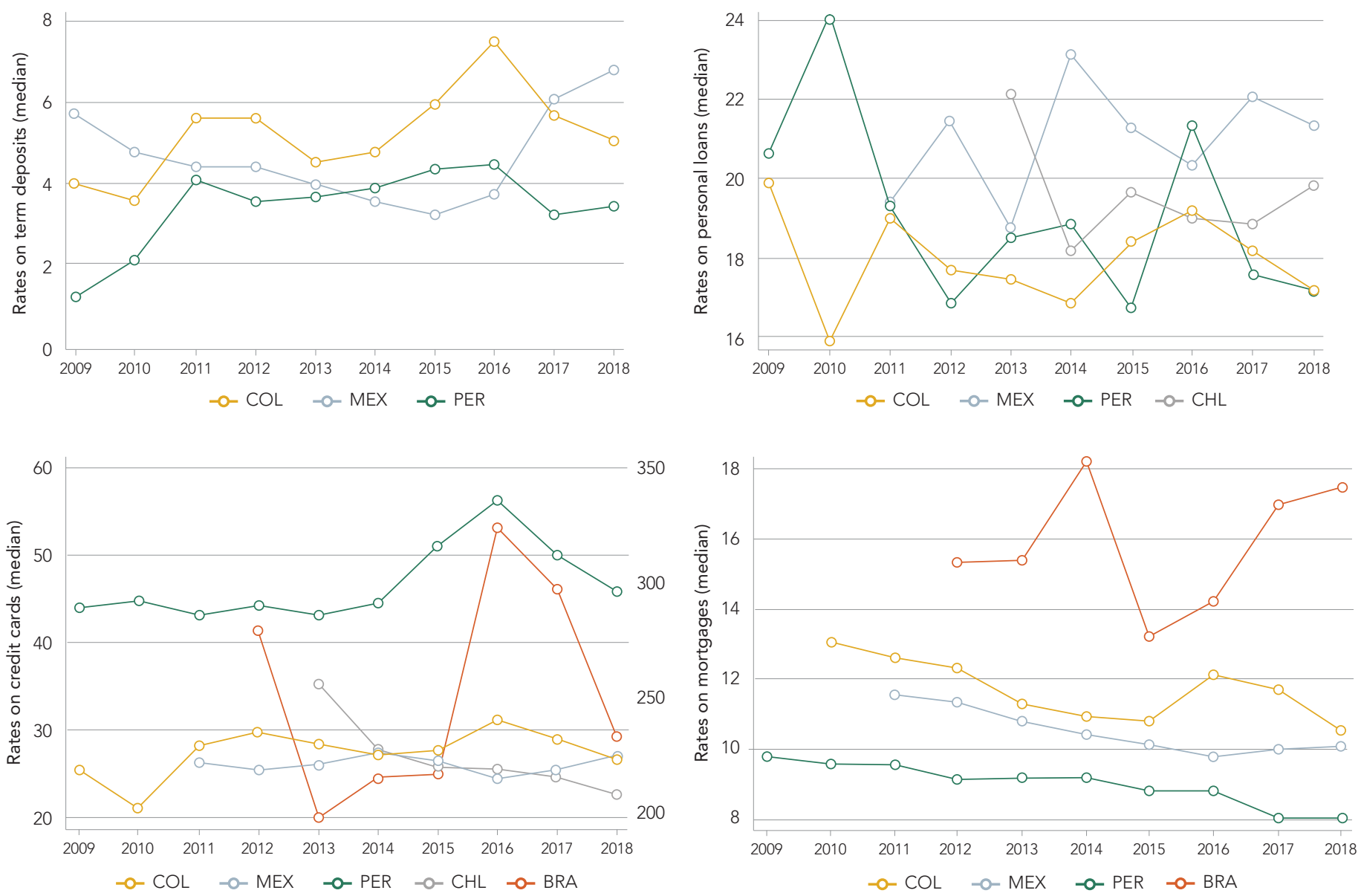

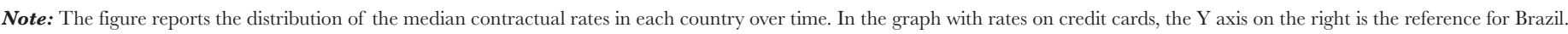


The development over time of median rates on mortgages is smoother, with the greater variation recorded by Brazil. Brazil also has the highest absolute value of the median rates on mortgages (on an annual basis) over the period and the value in 2018 was higher than the value recorded in 2013. Colombia, Mexico, and Peru show a downward path in the interest rates on mortgages over the period.
The product-specific Herfindahl-Hirschman Indexes (HHIs) exhibit moderate levels across countries. In general, concentration levels are moderate except in the mortgage market in Brazil. Brazil and Peru have the most concentrated markets across products. Colombia and Mexico have the least concentrated markets. Mexico also shows a downward trend in the concentration indexes in all the lending and deposit products under analysis (Figure 8).

FIGURE 8: EVOLUTION OVER TIME OF THE CONCENTRATION INDEX BY PRODUCT AND COUNTRY
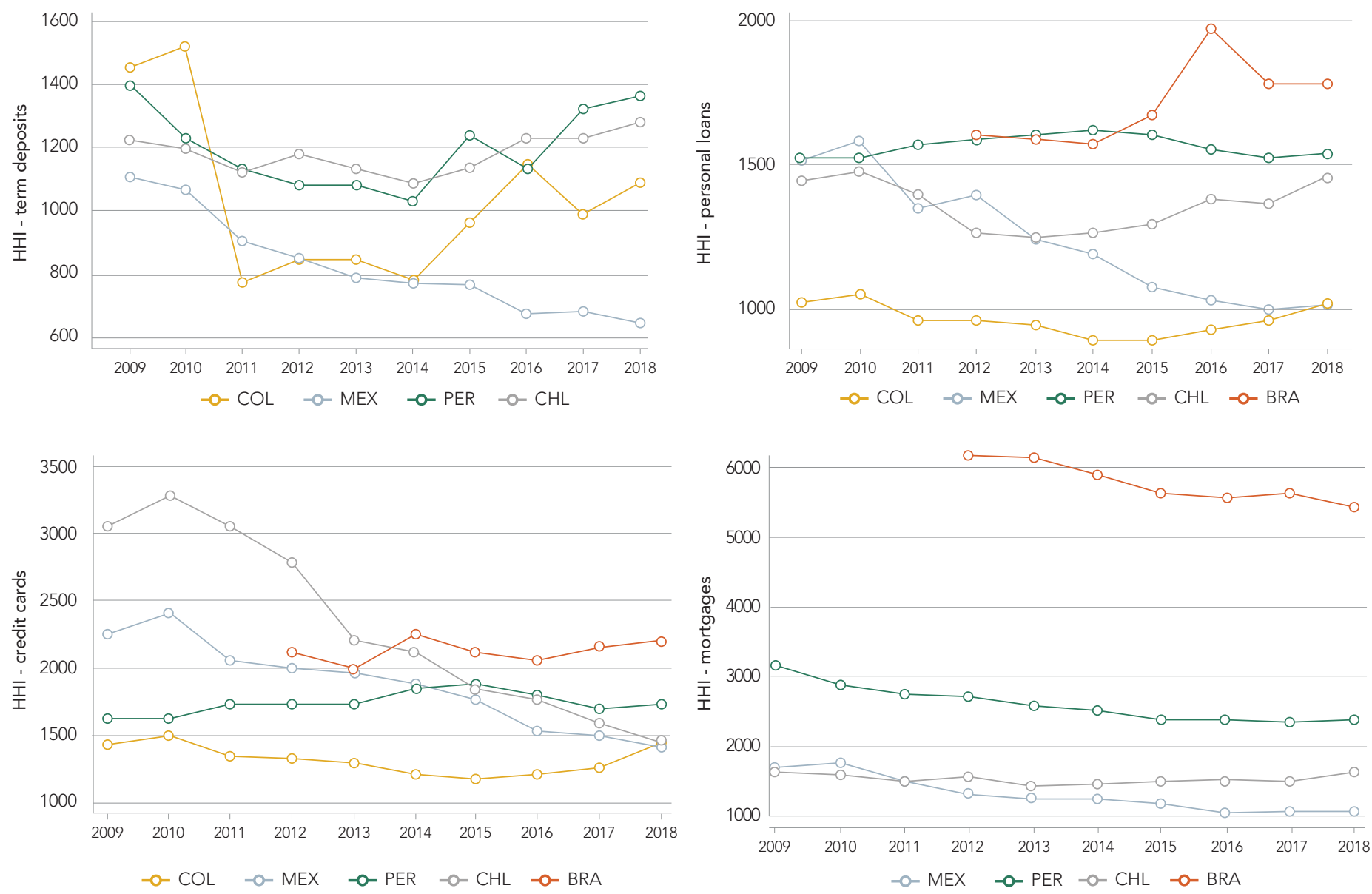

Note: The figure reports product-specific HHIs on a scale of 10,000. High values denote high concentration. 
Concentration is relatively low in the market of term deposits. ${ }^{13}$ Mexico shows a downward trend over the period. Colombia recorded a high drop in the HHI from 2010 to $2011 .{ }^{14}$ Since 2011, the concentration index for term deposits has shown an upward trend. Chile shows little variation of the concentration index over time. Peru displays a decrease in the HHI from 2009 to 2014 and an upward trend since then.

\section{Concentration is relatively low in the market of} personal loans. Brazil and Peru have the highest absolute values. Colombia and Mexico display the lowest values. For the former country, the development of the concentration index over time is smooth. For Mexico, we observe a downward trend with a drop of almost 500 points in the HHI since 2009. Chile shows a smooth development in the HHI over time, with the level in 2018 just 8 points higher than 2009.

\section{Concentration is relatively moderate in the market} of credit cards. Brazil has the highest absolute level as per end-of-2018 data. Chile shows a marked downward trend in the concentration in the credit card market, with a noticeable drop of 1,600 points from 2009 to 2018. A similar downward trend is observed in the case of Mexico. Chile, Colombia, and Mexico have the lowest absolute value of the HHI as per end-of-2018 data.

\section{Brazil and Peru show highly concentrated mortgage} markets. The HHI is twice as large in Brazil as Peru and more than three times the HHI computed for Chile and Mexico. In general, all the time series are smooth, meaning that market shares do not vary substantially over time. As observed for the other financial products, in Mexico the mortgage market has become less concentrated over time with a drop of more than 600 points between 2009 and 2018.

\footnotetext{
13 The U.S. Department of Justice (DOJ) considers HHI (on a 10,000-point basis) in excess of 2,500 as an indication that a market is highly concentrated.

14 The large drop from 2010 to 2011 could be explained in part by a composition effect. In 2010, there were 19 credit institutions reporting information on the volumes of term deposits, while in 2011 this number is 23.
}

LA-5 countries show persistence of market shares, suggesting low contestability in each product market. A vibrant market involves contestability of market shares of participating banks. If the ranking of financial institutions according to their market share in a product does not vary much from one year to the next, this may imply low contestability (Covarrubias, Gutiérrez, and Philippon 2020). Figure 9 reports information on the degree of association between the ranks in a country in a year for the distinct financial products and a lag of two years. ${ }^{15}$ If the correlation between the relative positions of banks in terms of market shares is close to one over a two-year period, it means that market shares are persistent and contestability in the market is low. Across products and countries there is a high association between the rank in a year for a product and the same rank two years later. This indicates that there is low contestability in the four markets across countries.

\section{LA-5 countries bar Mexico also show low turnover at} the top. Industries characterized by a transient dominance of the firms at the top are more competitive (Philippon 2019). Figure 10 shows that the turnover at the top, that is, the changing composition of the top 3 banks per market shares, is low except for Mexico in the term deposits market. On a three-year window, the probability of being one of the top 3 banks in terms of market shares across products and countries is well above 60 percent. Brazil and Peru show the lowest reshuffling (that is, the lowest height of the bars), ${ }^{16}$ with the probability of being one of the top 3 banks three years later approaching 1 in all the markets. In Chile, the credit card market shows the higher reshuffling whereas in Colombia the term deposit market is more dynamic at the top. Finally, Mexico shows the highest reshuffling in all the markets except in the credit card market.

\footnotetext{
15 We also run the same analyses using a one-year and a three-year lag. Results do not vary substantially though the association between ranks spaced three years apart is indeed of lower magnitude than the association computed with a year lag.

16 Reshuffling, or the likelihood of being replaced, can be computed as 1 minus the probability of staying at the top.
} 
FIGURE 9: PERSISTENCE OF MARKET SHARES OVER A TWO-YEAR PERIOD

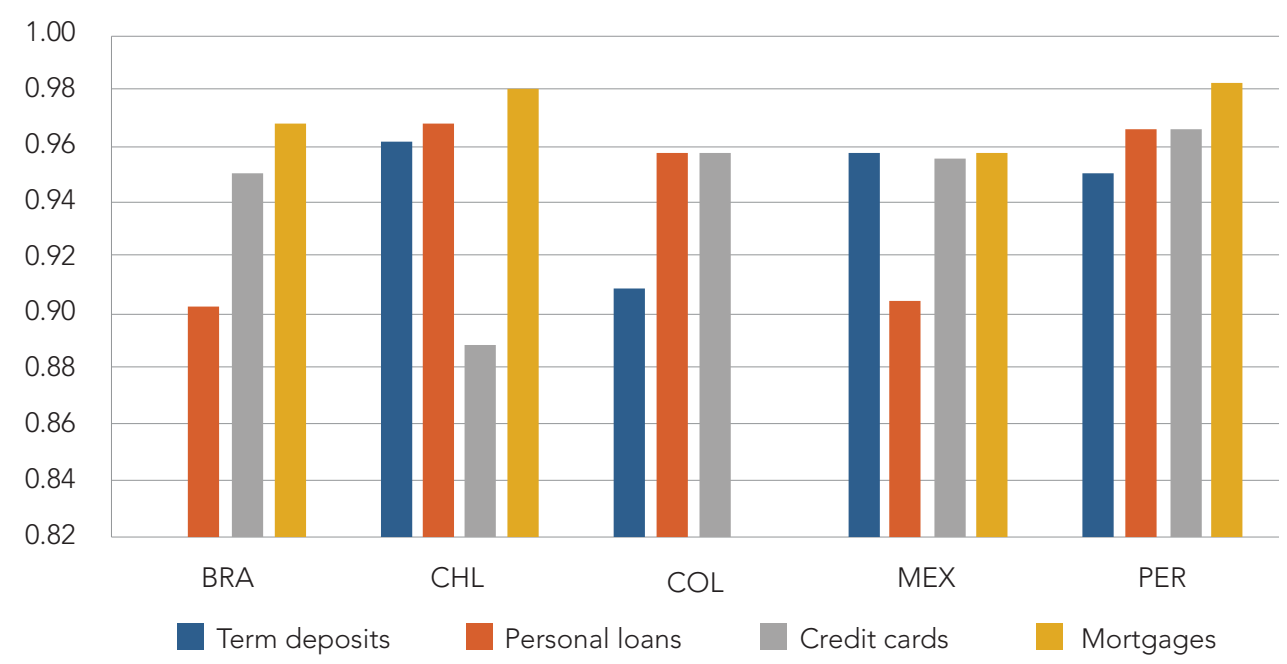

Note: This figure presents information on the pairwise correlation between the current ranking of institutions in a country in a year according to the market share in a financial product and the ranking for the same product two years later. The Pearson correlation coefficient is computed using a moving window over 2009-2018. For some countries, the window is shorter depending on the availability of data.

FIGURE 10: TURNOVER ATTHE TOP OVER A THREE-YEAR PERIOD

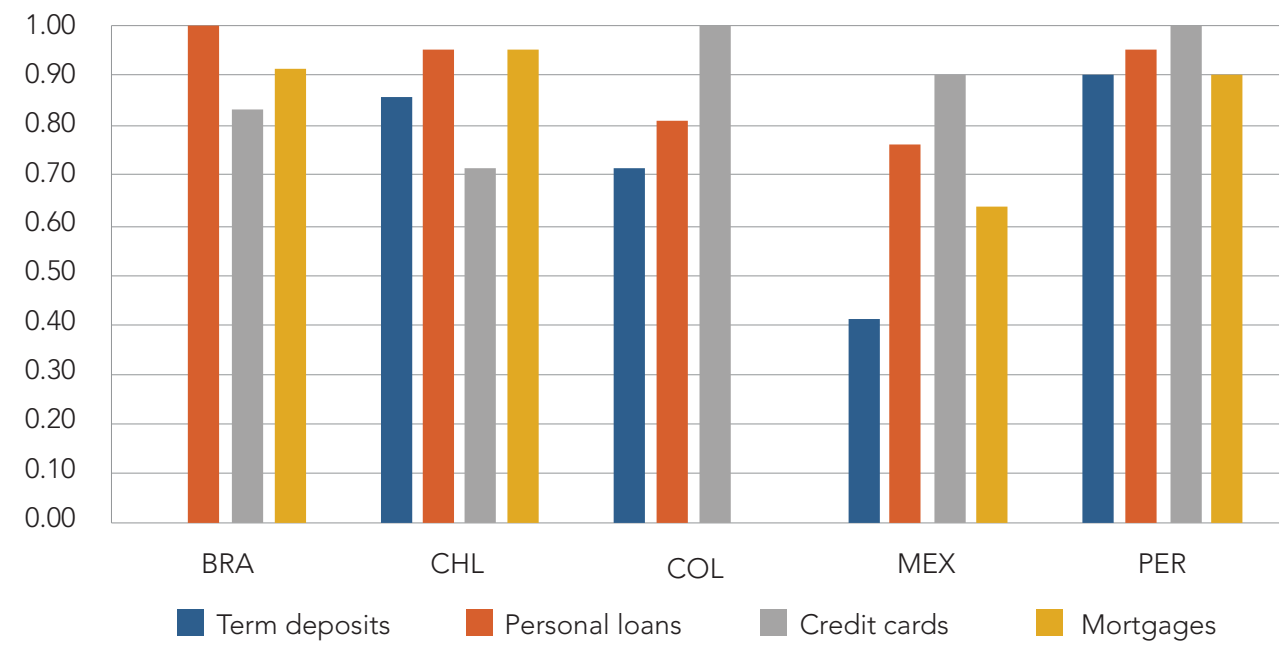

Note: This figure presents information on the probability for top 3 banks by market share in a country, year, and product of being ranked top 3 three years later. Reshuffling, or the

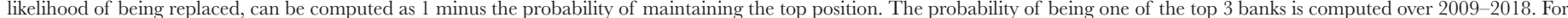
some countries, the window is shorter depending on the availability of data. 


\subsection{RELATING \\ CONCENTRATION TO PRICING POWER IN RETAIL BANKING IN LA-5}

In this section, we relate concentration to pricing power in retail banking in LA-5. We first report the development over time of the median value of margins per product defined with reference to money market rates. A markdown expresses the difference between what can be earned on a liquid investment and bank deposits. The higher the negative gap, the more the pricing power banks have in setting deposits rates. A markup expresses the same concept, but it is calculated as the difference between a loan interest rate and a reference price. The higher the positive difference between the lending rate and the market rate, the higher the pricing power of the bank.

Pricing power in the market of term deposits is lowest in Mexico. The median bank in Mexico provides interest rates on term deposits higher than money market rates (Figure 11). By the end of 2018, both in Colombia and Peru, the rates on bank term deposits are lower than money market rates, suggesting the presence of some pricing power for these countries.

\section{FIGURE 11: DIFFERENCE BETWEEN CONTRACTUAL RATES AND MONEY MARKET RATES}

(PERCENTAGE POINTS)
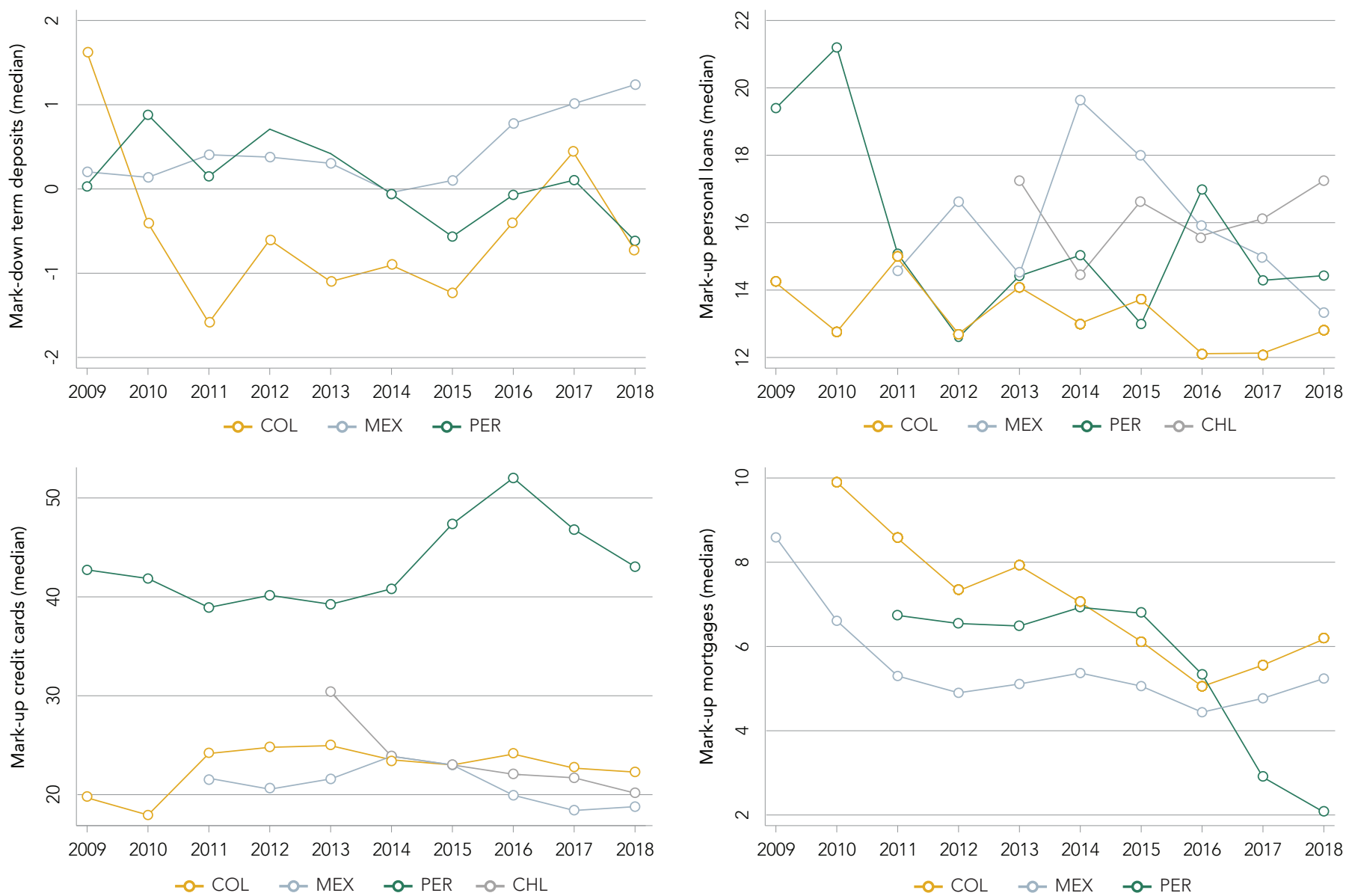

Note: For term deposits, the difference is expressed as a markdown, that is, money market rate minus the median value of the contractual rate on term deposits. A negative value denotes

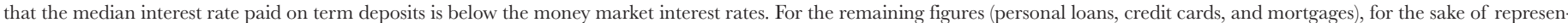
tation, we do not report data on Brazil for credit cards and mortgages. 
The development over time of the markups in the market for personal loans shows high variation across countries. In all countries for 2009-2018, the margin over money market rates is greater than 12 percentage points. Colombia has the smoother development over time and the lowest value of the margin. By the end of 2018, Chile had the highest margins, followed by Peru and Mexico. Mexico experienced a noticeable reduction in the median markups since 2014.

The median markup on credit cards in each country is the highest among lending products. In all countries in all years, bank median margins over money market rates stand at or above 20 percentage points. Peru has the highest median markup value for all the years. In 2018, the median Peruvian bank charges were approximately 40 percentage points more than money market rates. Brazil has the second highest value for the markup and the highest variability of the median value over time. Colombia, Peru, and Chile have a smoother development over time of the median value of the markup which in 2018 was around 20 percentage points.

Pricing power in the market of mortgages is highest in Brazil. Brazil also shows large variability in the time series development of the median markup. Mexico has shown a noticeable decrease since 2015 and in 2018 had the lowest median value among the LA-5 countries. Colombia and Peru show a similar development over time with margins first decreasing up to 2016 and a recent increase in 2017 and 2018.

Econometric estimates show that increases in market shares are correlated with less competitive pricing in both lending and deposit products in LA-5, except in the mortgage market. Margins across products can be explained by a set of determinants, including the market shares of individual banks (see Annex 1 for a detailed explanation of the econometric specification). We differentiate between lending products and deposit products and find that, pooling together information on all countries, in both cases market shares are statistically and significantly associated with margins except for the market of mortgage loans. A possible explanation of the fact that there is no significant relationship between market structure and pricing power in the mortgage market is that in LA-5 there is a general practice to subsidize interest rates and/or to remortgage and securitize loans, which may end up contaminating the relationship.

Analyses at the country level show that higher market shares in the credit card market segment are associated with higher markups across all LA-5 countries (Figure 12). In contrast, in the market of personal loans, in Mexico and Peru higher market shares are correlated with a lower premium over money market rates. In the market for term deposits, for all the countries for which information is available, we find a negative relationship between higher market shares and markdowns, implying lower relative deposit rates for banks with the highest market share. The econometric analyses also offer insight into other elements that are worth a more in-depth exploration. For example, domestic private banks appear to have lower margins than state-owned banks in both Chile and Mexico. In contrast, foreign ownership in Chile, Colombia, and Peru is correlated with higher margins.

\section{FIGURE 12: RELATIONSHIP BETWEEN PRICING POWER AND MARKET SHARE}

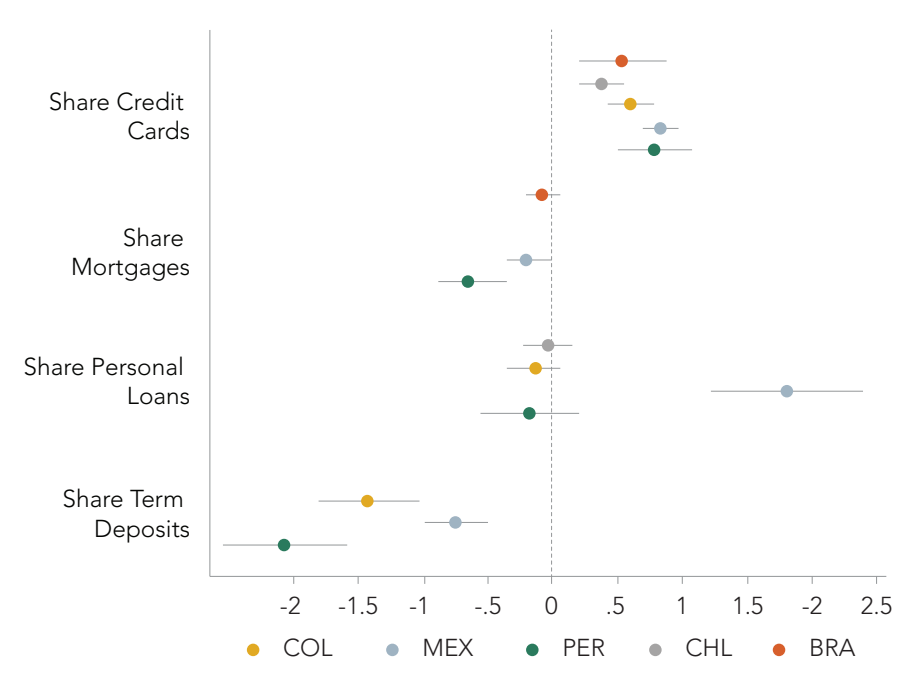

Note: This graph reports the coefficients and confidence intervals at the 5 percent level of bank market shares in four banking products, as per Equation (A1) in Annex I. Coefficients for Brazil are rescaled for visual purposes. 


\subsection{CONCLUSION}

This chapter analyzes the market structure, market power, and pricing power of LA-7 countries. The descriptive evidence shows that overall market concentration has increased since 2009. This development has been accompanied by an increase in the stringency of the requirements to obtain a banking license and an increase in the percentage of denied entry applications. Notwithstanding these barriers to entry, LA-7 countries in general remain open to foreign entry and the threat of new entrants indicates the presence of competitive pressures. At the same time, banks in LA-7 may enjoy pricing power because in some countries the markups have trended upward since 2005.

Descriptive analyses and econometric estimations suggest that higher market shares are associated with higher pricing power, but the relationship changes across financial products. Concentration indexes and contractual rates vary across products and countries. Banks' revenues and costs may change recurrently depending on certain factors such as the degree of market competition. This in turn generates variability in the contractual rates offered by banks. Where markets are more concentrated and there is persistence of market shares and low turnover at the top, the difference between contractual rates and money market rates is higher. Likewise, econometric estimates show that higher bank market shares are associated with less competitive pricing in both retail deposit and lending products, except in the mortgage market. Overall, the chapter offers evidence that, to capture the effect of concentration on pricing power, analyses should be conducted at the product level. This is because more disaggregated measures offer a more precise picture of the effect of market structure and contestability on bank pricing power. More research is needed to disentangle the complex relationship between market structure and market power at the country product level. 



\section{CHAPTER 2:}

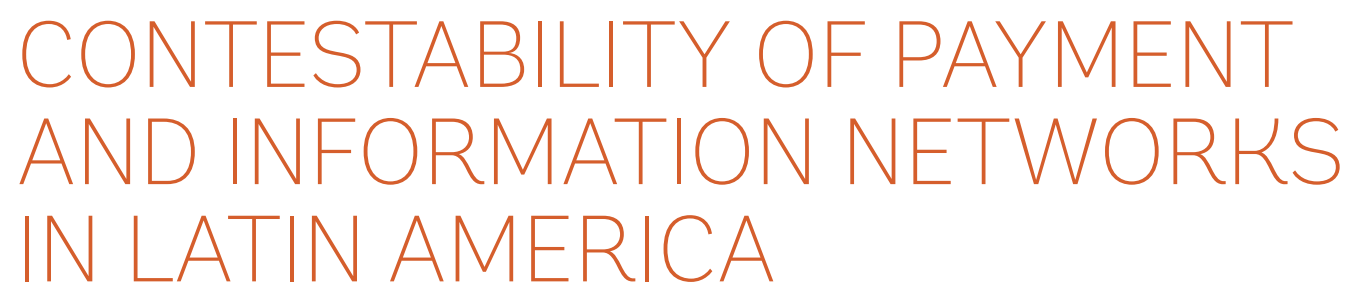

This chapter provides an overview of the key elements of the financial infrastructure that affect competition in the retail banking market in LA-7. The chapter uses survey data with information collected through analytical work conducted in these countries. In the payment systems, where many markets operate with multisided platforms, practices that limit competition may have an impact on several participants, including consumers, merchants, and service providers. Innovation in payment systems may create new opportunities for players to enter the payments services while creating new competition-related challenges for regulatory authorities. This chapter also analyzes the key features of credit reporting systems in LA-7 economies. Specifically, it analyzes information networks in $L A-7$ to understand how they affect the provision of retail credit through aspects such as the vertical integration of the infrastructure, legal and regulatory barriers that might impede the sharing of comprehensive credit information, and behavioral aspects on information sharing arrangements. 
2.1.1 GENERAL COMPETITION ASPECTS

OF PAYMENT INFRASTRUCTURE

This section describes competition aspects of payment systems and arrangements for cards and electronic transfers. A payment system is the technical, operational, institutional, financial, and legal arrangement that enables the transfer of funds between users of different payment service providers participating in the system. Electronic transfers, such as credit transfers, and card payments are processed through similar payment infrastructures. However, processes, participants, and roles that participants play vary across the two payment instruments. Assessment of the competition conditions for each type of payment instrument and the systems that enable their functioning must be carried out separately.

\section{Usage of digital payments and cashless transac-} tions ${ }^{17}$ is growing in LA-7. Cashless transactions are growing across some LA-7 countries, while digital payments usage is increasing across all LA-7 countries (Table 1). In consequence, the number of transactions going through payment systems and arrangements has also increased.
Higher adoption of cashless and digital payments has spurred growth of the number of transactions processed through payment systems and arrangements. For example, Peru's Cámara de Compensación Electrónica, which settles electronic transfers, has seen an increase in the volume of transactions, which went from settling 217 million credit transfers in 2014 to 396 million credit transfers in 2019. ${ }^{18}$ In Mexico, the Sistema de Pagos Electrónicos Interbancarios went from settling 267 million transfers in 2014 to 838 million in $2019 .{ }^{19}$ For card payments, in Colombia purchases with debit cards went from 26.7 million in December 2014 to 54 million in December 2019. ${ }^{20}$ In Uruguay, purchases with credit cards went from in 45.6 million in the second semester of 2014 to 87.5 million in the second semester of 2019, and purchases with debit cards increased from 10.1 million in the second semester of 2014 to 113 million in the second semester of 2019.

\section{New payment services providers and the digital} economy will increase usage of digital payments. Increased adoption of digital payments is expected as authorities create legal and technological railways for their usage. Most countries (Brazil, Colombia, Mexico, Peru, and Uruguay) have implemented regulation to allow financial institutions and new participants to issue electronic money,

\section{FIGURE 13: PAYMENT SYSTEM WORKFLOW AND PARTICIPANTS}

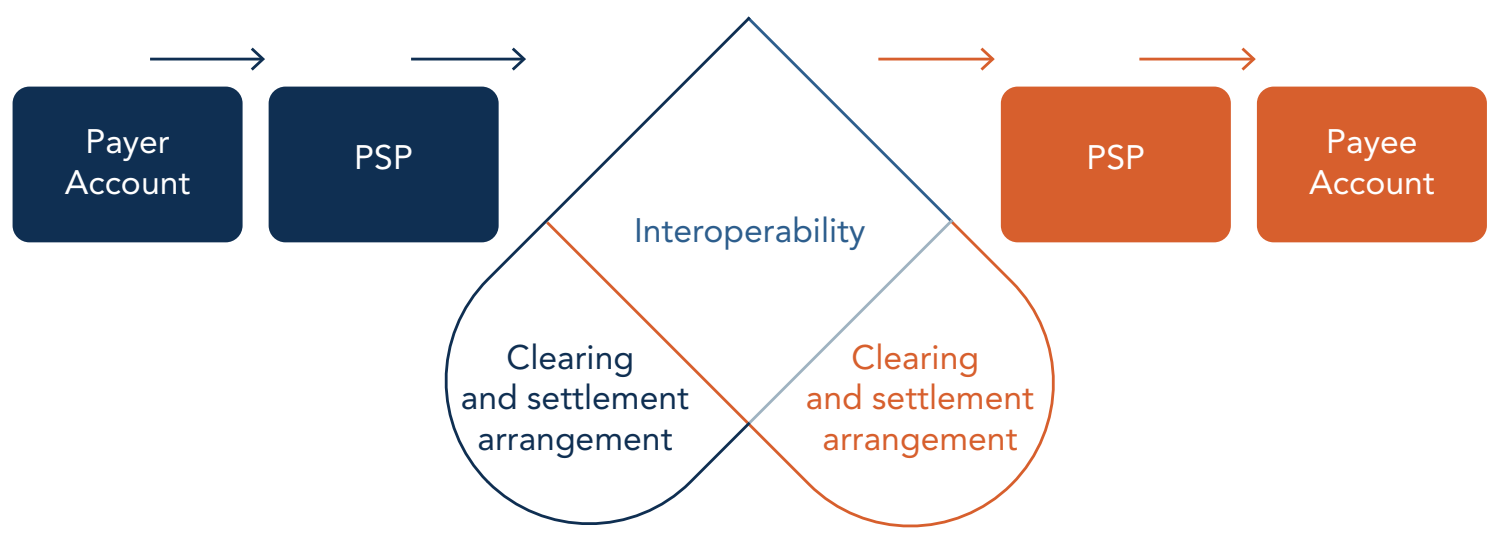

Source: Own elaboration.

17 Cashless transactions include electronic funds transfers, cheques, card payments, and e-money transactions.

\footnotetext{
18 https://estadisticas.bcrp.gob.pe/estadisticas/series/mensuales/sistema-de-pagos

19 https://www.banxico.org.mx/SieInternet/consultarDirectorioInternetAction.do? sector $=5 \&$ accion $=$ consultarCuadro\&idCuadro $=\mathrm{CF} 252 \&$ locale $=\mathrm{es}$

${ }^{20}$ https://www.superfinanciera.gov.co/publicacion/60952
} 
TABLE 1: USAGE OF DIGITAL TRANSACTIONS IN LATIN AMERICA

The number of cashless payments per capita is growing....

\begin{tabular}{l|c|c}
\hline & $\mathbf{2 0 1 3}$ & $\mathbf{2 0 1 8}$ \\
\hline Argentina & 29 & 53 \\
Brazil & 127 & 166 \\
Mexico & 27 & 40
\end{tabular}

Source: Bank for International Settlements.

Note: a. Cashless payments per capita.

b. Share of adult population that made or received digital payments.

which can be used through electronic transfers or cards or a combination of both. ${ }^{21}$ Observers are also forecasting an increase in digital payments due to a higher number of transactions carried out in online and e-commerce platforms. ${ }^{22}$

\section{Access to payment infrastructures is decisive in banks' value offer. Access to payments infrastructures} can represent a competitive advantage for banks, which depends on the scope and features of the infrastructure itself. For example, a payment infrastructure that settles and credits transactions in real time allows its participants to offer a more convenient service than that offered by participants of an infrastructure that settles and credits payment transactions up to one day after a transaction is submitted.

\section{Some jurisdictions have explicit regulatory powers to promote competition in payments markets. In} some countries (Peru, Mexico, and Brazil), central banks and financial authorities have powers to establish conditions that promote competition in payments markets. ${ }^{23}$ In Mexico,

21 Brazil created the Instituições de pagamento, Colombia the Sociedades Especializadas en Depósitos y Pagos Electrónicos, Mexico the Instituciones de Fondos de Pago Electrónico, Peru the Empresas Emisoras de Dinero Electrónico, and Uruguay the Instituciones Emisoras de Dinero Electrónico.

22 https://newsroom.mastercard.com/latin-america/files/2019/12/Whitepaper-Digital-Security-mastercard-ENG-simples-FINAL2.pdf Global payments report, Worldpay, 2018.

${ }^{23}$ https://www.bcrp.gob.pe/docs/Sistema-Pagos/Ley-29440.pdf ....as is the usage of digital payments ${ }^{b}$

\begin{tabular}{l|l|l|}
\hline & $\mathbf{2 0 1 4}$ & $\mathbf{2 0 1 7}$ \\
\hline Argentina & $34 \%$ & $40 \%$ \\
\hline Brazil & $50 \%$ & $58 \%$ \\
Chile & $53 \%$ & $65 \%$ \\
\hline Colombia & $30 \%$ & $37 \%$ \\
Mexico & $29 \%$ & $32 \%$ \\
\hline Peru & $22 \%$ & $34 \%$ \\
Uruguay & $38 \%$ & $59 \%$ \\
\hline
\end{tabular}

financial authorities have powers to enact and enforce pro-competition regulation, for example, by establishing regulation of fees, and can request competition authorities to exercise antitrust actions over financial entities, including administrators and participants of payment arrangements. In Brazil, coordinated efforts between the central bank and economic authorities to analyze the structure and competition aspects of the card payments markets resulted in measures implemented by each authority within the sphere of their responsibility to promote competition. The Brazilian competition authority has acted upon practices that limit competition in the card payments market by establishing 'cease and desist' agreements, while the Government of Brazil enacted Law 12,865, which allows the Central Bank of Brazil (BCB) to enforce pro-competition behaviors on card schemes, including interoperability and efficiency of these networks.

The responsibility for payment systems oversight and regulation falls primarily on central banks. In all jurisdictions, the responsibilities of the financial authorities with regard to the regulation of payment systems and schemes are clearly established, with the central banks having the primary responsibility for oversight and regulation of the ecosystem. Some regulatory frameworks assign additional responsibilities to other financial authorities. Such is the case with Colombia, where the banking supervisor regulates low-value payment systems and on par the central bank establishes specific regulation for the low-value payment 
systems under its administration. The case of Chile is similar to that of Colombia, since the central bank regulates high-value payment systems and has powers to regulate low-value payment systems. However, the regulation of low-value payment systems is carried out by the banking supervisor.

Competition in payments markets occurs not only between providers of a specific payment mechanism but also between different types of payments instruments. The emergence of real-time payments and the simplification of person-to-person and person-to-business transfers presents a new challenge for other means of payments such as cards. The new transfer systems have features that could make them more attractive to payers and merchants. For example, real-time transfer systems provide instant crediting of funds, while card payments credit funds to merchants $2-30$ days after a payment is completed. Additionally, to foster competition among payment methods, some authorities are promoting the adoption of real-time transfer systems by eliminating the fees charged to customers for their use, while card payments are still considered expensive for both merchants and payers.

\section{Nondiscriminatory access and competition are} principles included in all the regulatory schemes of the surveyed jurisdictions. However, only few countries have implemented concrete regulatory actions to implement open and nondiscriminatory access. For instance, in most of the countries the regulation for the cards market is underdeveloped and either allows unrestricted vertical integration that could, under certain conditions, enable or facilitate practices that limit competition or is outdated and does not capture new technological developments and business models. In addition, the implementation of international principles that promote fair access and good corporate governance is carried out heterogeneously and, in many cases, does not reach retail payment systems.

\section{The retail payments market is still concentrated} in banks, but new payment services providers and models have appeared, for which access to payment systems and infrastructure is crucial. Historically, banks, along with central banks, have played an essential role in the development of payments markets. In most of the surveyed countries, the core retail payments infrastructure either is controlled by the banking sector or, where managed by the central bank, is developed around a bank-centered business model. Because of this, access requirements and participation costs fit banks' business model, risk framework, and target market. Furthermore, in the case of payment systems, as they could be a transmission channel of the effects of technological, operative, and financial disruptions, financial authorities have taken a cautionary stance regarding their access policies. In recent years, new players have been leveraging technology to develop digital payment solutions that facilitate their adoption or target unattended markets, which in turn would help advance public policy objectives such as financial inclusion. For these players to develop usage of their payment services, they need to be interoperable with incumbents and between themselves, which requires having access to payments infrastructure that allows the exchange of payments between different payment services providers. For example, a new player that offers a mobile wallet might have difficulties expanding its customer base if it cannot access a payments infrastructure and its users are unable to make payments to accounts residing in other providers. In this case, the user might choose to either stop using digital payments or switch to an incumbent service that has access to infrastructure and allows to make payments to a larger number of counterparts.

As access to payment systems may be limited to new payment services providers, indirect access is being used to exchange payments across different entities. Indirect access occurs when a payment services provider that does not participate in the payments infrastructure exchanges payments with other counterparts through a direct participant. However, this form of access can favor practices that limit competition such as charging indirect participants excessively high prices for payments exchanged through the infrastructure or imposing operational restrictions that affect the convenience and features of the payment service.

The emergence of new payment services providers and models requires that authorities rethink access to payment systems policies, which requires a 
risk-based approach. While new payment services providers are increasingly becoming regulated entities, this does not imply that they are eligible for participation in established payments infrastructures. Also, authorities may allow access for new providers but do not implement access requirements that are commensurate with the risk each of the entities pose to the system. In many cases, new payment services providers lack the diversification, size, and sophistication of banks, which may call for less stringent participation requirements. To balance access policies, these must be designed under a risk-based approach that favors proportionality. International standards, particularly the Committee on Payments and Market InfrastructuresInternational Organization of Securities Commissions Principles for Financial Market Infrastructures, provide a framework on how to open participation and implement risk-based access rules. ${ }^{24}$

Exclusionary practices and other practices that limit competition enabled by vertical integration pose a significant challenge for payments markets across the region. Participants of payments markets have created vertical structures that allow them to have business interests in different parts of the payments cycle. From this, practices that limit competition may arise such as exclusivity agreements, denying access to competitors to key components of the payments infrastructure, setting overly high standards of participation in payments infrastructures, and tying sales of services and products to contracting of processes required to provide payments services.

The payments market could benefit from efforts by the international community to design competition standards, which should consider the application of the proportionality principle. The emergence of new vulnerabilities and business models in the payments market poses a challenge for the authorities of the region. On the one hand, regulators have taken an active role in strengthening information security, operational continuity, and consumer protection, which has resulted in more robust requirements for participation in payment infrastructures. On the other hand, the promotion and development of innovative business models in the payments market has also

24 See principles 2, 18, 19, and 21 . become a priority for regulators. Balancing these public policy objectives requires a policy evaluation framework that simultaneously integrates the development and the stability of the payments ecosystem and implements the requirements for participation in payment infrastructures that are commensurate with the specific risk that each entity poses to the ecosystem.

\subsubsection{COMPETITION ASPECTS IN THE ELECTRONIC TRANSFERS MARKET}

There are electronic transfers' payment systems that are specifically designed to serve the retail market. Most countries (Brazil, Chile, Peru, Argentina, and Colombia) have payment systems dedicated exclusively to process transfers for the retail market, while in other countries the payment infrastructure for low- and high-value transfers is the same. In the case of Mexico, the Sistema de Pagos Electrónicos Interbancarios (SPEI), operated by the central bank, is the system responsible for settling most transfers made in the country including high-value transfers. Carrying out settlement for high- and low-value payments in the same infrastructure may require the implementation of more stringent participation requirements to mitigate operational or technological disruptions that could endanger the financial resources that run through the system..$^{25}$ Brazil's case is similar to Mexico, where the Sistema de Transferência de Reservas (STR) settles highand low-value transfers, although most low-value transfers are sent through the Câmara Interbancária de Pagamentos (CIP) system. ${ }^{26}$

\section{Ownership of electronic transfers' payment systems} is in the hands of central banks or commercial banks. In some countries (Argentina, Peru, and Chile), the retail payment systems are operated and managed by commercial banks, while in Brazil and Colombia there are two payment infrastructures for retail payments with different types of ownership. In the case of Colombia, the payments infrastructure operated by commercial banks

\footnotetext{
25 https://www.banxico.org.mx/publicaciones-y-prensa/informe-anual-sobre-las-infraestructuras-de-los-me/\% 7B47E2C88D-F4B 1-1D34-29138E25F249E6F1\%7D.pdf

${ }^{26}$ https://www.bcb.gov.br/en/legacy?url=https:\%2F\%2Fwww.bcb.gov. br\%2Fpom $\% 2 F s p b \% 2 F I n g \% 2 F f u n d s . a s p \% 3 F i d p a i \% 3 D$ paysysdata
} 
concentrates the largest number of person-to-person and person-to-business transactions, while the additional infrastructure that settles retail payments is operated and owned by the central bank. In Brazil, the private infrastructure is the one that processes the largest number of retail transfers. ${ }^{27}$

\section{In some countries, open and nondiscriminatory} access to payment systems is sought through the implementation of international standards. The Principles for Financial Markets Infrastructures (PFMIs) published by the Bank for International Settlements in 2012 comprise different elements and good practices that should be observed by different types of financial market infrastructures, including payment systems. The PFMIs include a principle for access and participation in financial market infrastructures, which states that financial market infrastructures should allow for fair and open access. ${ }^{28}$ Some countries like Argentina have included the PFMIs in their regulatory framework ${ }^{29}$ and apply this framework to systemically important payment systems, which in the case of Argentina include retail payment systems. Implementation of the PFMIs at the regulatory level implies that entities must self-assess against the principles and address any gap that is detected through the assessment. Chile has followed a similar approach to Argentina's, although PFMIs are applicable only to high-value payment systems. ${ }^{30} \mathrm{In}$ addition to the explicit adoption of PFMIs, other countries have integrated the principles as part of their regulatory policy. Some central banks (Mexico and Brazil) have stated that the PFMIs constitute the public policy framework under which they oversee and regulate payment systems. ${ }^{31}$

In most jurisdictions, access requirements to payment systems are regulated and authorized by financial authorities. The requirements for participation in payment infrastructures managed by public

\footnotetext{
27 https://www.bcb.gov.br/en/financialstability/paymentssystemstatistics

${ }^{28}$ https://www.bis.org/cpmi/publ/d10la.pdf

29 https://www.bcra.gob.ar/Pdfs/Texord/t-pimf.pdf

${ }^{30}$ https://www.bcentral.cl/documents/33528/115568/CapIIIH.pdf/ f2156903-4051-7d6c-0e68-67c7a4c36c2a?t=1580124215227

${ }^{31}$ https://www.bcb.gov.br/pom/spb/ing/Comunique_DEBAN_25097_ en.pdf

https://www.banxico.org.mx/sistemas-de-pago/d/\%7B9ACA4DC8-2B968EB3-6FF3-F58DDFA3FE51\%7D.pdf
}

entities are determined by the administrators themselves; in the case of private infrastructures, in most countries (Argentina, ${ }^{32}$ Brazil,${ }^{33}$ Colombia,${ }^{34}$ Peru, ${ }^{35}$ and Uruguay $^{36}$ ), it is established at the regulatory level that the participation requirements should be fair and nondiscriminatory. However, in most cases, regulation does not cover specific guidelines to ensure nondiscriminatory access. In some jurisdictions, payments infrastructure access requirements have become hardened due to new vulnerabilities. In some countries, the recent occurrence of cyberattacks on the payment infrastructure has led to a tightening of access requirements, including additional measures for managing information security risks.

Specifying the responsibilities and operational procedures to be implemented in a payment system provides certainty for participants and allows the establishment of a level playing field for participants. In most countries (Argentina, Peru, Uruguay, and Mexico), the authorities have established minimum operating requirements for payment infrastructures, either by specifying the operational procedures to be followed by infrastructures or by approving operating manuals and regulations. However, it would be important to provide more information on the aspects and criteria that the authorities used for the establishment or approval of operating requirements and how they influence competition and fair access to payment systems. In this regard, criteria might be related to cybersecurity and operational and business continuity concerns, which are essential to the reliability of the system (Box 1).

Authorities' criteria to regulate access and participation conditions are not clear, and current access conditions may lead to unjustified direct and indirect participation costs. Access and participation conditions imposed by payments infrastructure

\footnotetext{
32 http://www.bcra.gov.ar/Pdfs/comytexord/A2557.pdf

33 https://www.bcb.gov.br/content/financialstability/paymentssystem_docs/ Laws/Resolution2882amended.pdf

34 https://www.superfinanciera.gov.co/inicio/10083580

35 https://www.bcrp.gob.pe/docs/Transparencia/Normas-Legales/Circulares/2016/circular-013-2016-bcrp.pdf https://www.bcrp.gob.pe/docs/Transparencia/Normas-Legales/Circulares/2000/Circular-022-2000-BCRP.pdf

${ }^{36}$ https://www.bcu.gub.uy/Circulares/seggci2159.pdf
} 


\section{BOX 1: INFORMATION SECURITY IN MEXICO'S PAYMENT SYSTEM}

In 2018, the SPEI, operated by the Central Bank of Mexico, suffered six information security breaches that infringed the technological infrastructure of its participants to create and send apocryphal payments through this payment system. The breaches occurred as follows: The attackers infiltrated the systems of some participants to create apocryphal transfers, the transfers were transmitted through the SPEI, resources were sent to valid accounts located in other participants, accounts for which the attackers had information and documentation that allowed them to access the resources held in them, and subsequently the attackers attempted to withdraw the cash from these accounts.

It should be noted that the SPEI regulation was updated in 2017 to include measures focused on enhancing the information security framework of the system. The regulation mandated the delivery of a report to the central bank, in which participants attested for compliance of the new measures; however, the date of entry into force of these measures was January 2018 and the submission of the compliance report was scheduled for February of the same year. Of 100 entities participating in the SPEI, only 47 delivered the report in time, while the rest requested an extension for delivery in May of 2018.

As a result of these attacks, the central bank took the following actions:
- Adjustments and improvements to the SPEI regulation and operational manual, including performing confidence and integrity tests to participants' staff, as well as those of third parties providing information and communication technology services

- The appointment of an SPEI Chief Information Security Officer, who shall validate the participants' compliance with the information security requirements listed in SPEI regulation

- Cybersecurity event response protocols, which establish an alert signaling system (four levels), as well as actions and measures to be taken by participants according to the alert level

- The definition of requirements to strengthen the security elements in the provision of transfer services to the customers of companies that offer exchange or sale of virtual assets

- Financial authorities, financial institutions, and other authorities created a response protocol for incidents that compromised the information security of the financial entities.

Security breaches have spread to other channels, such as ATMs and mobile banking, and in 2019 the Bank of Mexico reported financial losses of approximately US $\$ 41$ million as a result of information security breaches.

Source: https://www.banxico.org.mx/spei/informacion-importante-situac.html.

https://www.banxico.org.mx/publicaciones-y-prensa/reportes-sobre-el-sistema-financiero/\% 7B04E197EE-B6FC-7BA1-72A0-32D3E6C9BF28\% 7D.pdf

administrators may create barriers of entry. Among the conditions imposed by administrators that could produce exclusionary practices, there are entry and participation fees that may be excessive and have detrimental effects for the participation of new payments services providers. Also, administrators can impose unjustified technical and operational requirements to raise the cost of participation and limit participation to a few entities. Other indirect costs that could, intendedly or unintendedly, create barriers of entry come from the types of entities allowed to participate in the infrastructure. If access conditions only allow banks to participate, then new providers will have to incur the costs of obtaining a banking license to be able to participate in the infrastructure. In some cases, administrators may use volume-based discounts or other benefits that can only be received by largest participants to reduce costs for these entities and exclude smaller participants. Across jurisdictions, the criteria that are being used by authorities to regulate access conditions for infrastructures and how they monitor the impact that fees and indirect costs have on participation are not clear.

\section{Vertical integration in the electronic transfers market can create incentives for practices that limit competition. Vertical integration in the electronic transfers markets occurs when a participant has control over different components or processes executed for exchanging electronic transfers. For example, a participant that provides}


electronic transfers to customers and co-owns the payment system will process and transmit the transfer of funds. A variation of vertical integration occurs when a provider of electronic transfers also controls the telecommunication network through which the transfers are initiated and transmitted. Vertical integration can be used to impose exclusivity agreements and conduct exclusionary practices (Box 2).

Participation in payment systems is mainly con-
centrated in banks, although system adminis-
trators have granted access to other types of
regulated financial institutions that meet par-
ticipation criteria. In some countries (Argentina and
Chile), participation in low-value payment systems is concentrated among banks. However, in most countries (Brazil, Peru, Colombia, Mexico, and Uruguay), regulation that favors open access to regulated financial institutions has generated a more heterogeneous participation in payment systems, and thus entities in the retail sector that serve retail niches not served by banks have access to the payments infrastructure. In addition, in these countries, new payment providers that are developing novel payment services, like fintechs, could potentially access payment infrastructures as most of the jurisdictions are implementing specialized figures that would allow them to become regulated financial institutions, in line with international experience (Box 3).

\section{BOX 2: PRACTICES TO LIMIT ACCESS TO ESSENTIAL COMPONENTS OF THE PAYMENTS INFRASTRUCTURE}

\section{The case of Safaricom and M-Pesa in Kenya}

Kenya's popular M-Pesa mobile money service is provided by Safaricom, a mobile network operator (MNO). Like other payment services in the market, M-Pesa's mobile money product works through Unstructured Supplementary Service Data (USSD), which allows to deploy mobile money services in basic or feature phones. USSD is provided by MNOs, so when an MNO also acts as a payments services provider, it vertically integrates its business units and may use such structure to indulge in anti-competition practices.

In 2017, the Competition Authority of Kenya (CAK) determined that Safaricom was taking advantage of its dominant position and indulging in anti-competition practices. Safaricom was charging excessively high prices to bank and non-MNO mobile money providers for their usage of USSD services. Furthermore, it was not disclosing prices to users. CAK mandated that prices were disclosed to users after initiating a transaction but before the funds were transferred to another account. It also reached an agreement with Safaricom to lower USSD prices.

Another finding by CAK showed that Safaricom was using its dominant position to impede interoperability on account-to-account transfers. One of the problems was the inability to instantly credit the receiver's account and the cost of sending money to other accounts outside the network was significantly higher.

CAK, in coordination with the telecommunication authority and the Central Bank of Kenya, implemented a strategy that consisted of soft regulation and moral suasion and allowed to test interoperability modalities. By October 2018, the three MNOs participated in the interoperability initiative.

\section{Restricting access to essential software and hardware components}

Another variation of vertical integration is related to a payment provider that controls essential components of software and hardware that are essential for digital payments; for example, a Big Tech that offers communication devices and payment services may restrict access to features of the devices such as biometric readers, near-field communication (NFC) technology, software, or cameras, which may be required to use a digital payment service provided by a competitor. In Germany, authorities are requesting that Apple opens its mobile wallet features to other providers.

Source: https://www.centerforfinancialinclusion.org/the-competition-authority-of-kenya-opts-for-pricing-transparency https://www.mobileworldlive.com/money/news-money/mobile-money-interoperability-goes-live-in-kenya/

https://www.pymnts.com/apple/2019/germany-to-force-mobile-payment-providers-to-share-systems-with-rivals/ 


\section{BOX 3: ACCESS TO PAYMENT SYSTEMS FOR NONBANK ENTITIES}

Jurisdictions outside the Latin America region have adjusted rules of access to payment systems to grant participation to nonbank entities.

\section{Switzerland}

In 2019, authorities allowed access to the Swiss Interbank Clearing system for entities licensed as fintechs. License is granted by the Swiss Financial Market Supervisory Authority (FINMA) under the compliance of certain requirements including meeting financial, anti-money laundering, and audit requirements.

\section{United Kingdom}

In 2017, the Bank of England communicated that nonbank institutions in the United Kingdom could hold an account in the Bank of England and access the payment systems as direct participants. In 2018, Transferwise became the first nonbank to access a payment system; in this case it acts as a direct participant on the Faster Payments system.

Financial authorities established a set of preconditions including being a regulated e-money or a payments institution, having the operational capacity to settle transactions in the real-time gross settlement system, and entering into legal agreements with the Bank of England.

Source: https://www.snb.ch/en/mmr/reference/pre_20190111/source/pre_20190111.en.pdf;

https://www.bankofengland.co.uk/-/media/boe/files/markets/other-market-operations/accessfornonbankpaymentserviceproviders;

https://www.bankofengland.co.uk/news/2018/april/non-bank-psp-access-to-the-payments-system-announcement.

Indirect participation in infrastructure could allow access by reducing requirements and costs of participation, but sponsors can impose additional burden to indirect participants. Given the costs of accessing payment systems, smaller financial services providers could use indirect participation schemes to access critical payment systems, but the lack of regulation of such schemes in some countries could potentially have consequences on competition and even hinder the stability of payment systems. On the one hand, direct participants would have control over the form, costs, and conditions for indirect participation, which could adversely affect competition in retail payments. On the other hand, the lack of regulation of this type of participation could prevent the system manager from observing risks arising from the concentration of payments made by an indirect participant. In other countries, regulation of indirect participation in payment infrastructures has become relevant in the context of the emergence of new payment services providers. In the case of Argentina, ${ }^{37}$ Peru, ${ }^{38}$ and Uruguay, ${ }^{39}$ these

\footnotetext{
${ }^{37}$ http://www.bcra.gov.ar/Pdfs/comytexord/A2557.pdf

${ }^{38}$ https://www.bcrp.gob.pe/docs/Transparencia/Normas-Legales/Circulares/2000/Circular-022-2000-BCRP.pdf

${ }^{39}$ https://www.bcu.gub.uy/Circulares/seggci2 159.pdf
}

agreements are formalized, while in $\mathrm{Brazi}^{40}$ a scheme for indirect participation will be put in place for the new instant payments system.

\section{Technological advancement and the digital economy} are expected to increase the demand for payment services, which has favored the emergence of new payment services providers. As mentioned, most jurisdictions have established a legal framework for new payment services providers. However, licensing of these entities does not imply that such entities are able to participate in retail payment systems, as participation may be restricted and granted only to banks. In this case, new entities can only provide payment services by creating a closed loop network, which limits the scope of their services and hampers their development.

\section{It is important to note that the regulatory framework of new payment services providers includes trans- actional limits, which is relevant in the regulatory design of payment infrastructures for transfers. In most countries (Brazil, Colombia, Peru, and Mexico), new payment services providers are designed to only serve the

\footnotetext{
${ }^{40}$ https://www.bcb.gov.br/content/financialstability/Communiques_ps_ docs/Communique_32927.pdf
} 
retail segment so transactional limits have been established for them to simplify the opening of accounts and promote financial inclusion, which in turn limits the risks that these entities can transfer to the payment system.

\section{The payment system operators have modernized} or have plans to modernize the payments infrastructure to offer continuous and faster payments

services. The increasing need to provide real-time payments has resulted in payment infrastructure owners implementing operational improvements or planning to modernize their technological platform. Mainly, infrastructure owners have focused on the development of real-time payment services with high availability (which means that the systems operate 24 hours a day and 365 days a year). These new operating models demand investment and could potentially increase the costs of participating in the payment's ecosystem.

\section{New payment mechanisms for the retail market} have been mounted on existing payment systems. In line with the efforts to modernize the payments infrastructures, initiatives for the promotion of digital payments have as a common component the usage of these infrastructures to mount payment mechanisms through mobile devices using QR technology, NFC, or payment buttons. In the case of Mexico, the central bank has set up its pull payments solution Cobro Digital (CoDi) through the SPEI platform, the Argentine central bank has integrated the Débito Inmediato (DEBIN) payments to the retail payment system Compensadora Electrónica (COELSA), and Colombia has mounted the Pago Seguro en Linea (PES) payment button in ACH Colombia. The integration of these technological solutions requires additional investments and participation costs for participants.

\section{In addition to traditional payment systems serving} the retail market, new payments platforms have been created for the operation of innovative payments models. Some countries, such as Peru with BIM and Argentina with Pago Electrónico Inmediato (PEI), have promoted the creation of payment platforms, which also carry out functions of a payment system and use mobile phones as their main access point and aim to send and credit resources in real time through a simplified user experience. To offer a simplified user experience, these platforms allow to identify beneficiaries' accounts by their cellphone numbers or aliases that the beneficiaries have designated themselves.

\section{Since these platforms have been created to advance} financial inclusion, some of them have sought to provide open access. In the case of Peru's BIM, access is open and participants include banks, payment services providers, and telecommunication services providers. ${ }^{41}$ Other platforms are mounted on existing networks, such as PEI in Argentina, which uses the RedLink and Banelco ATM network, and while interoperability among its participants is mandatory, participation is limited to banks affiliated with such networks. ${ }^{42}$

Fees are essential to promote competition between entities and even between means of payment. Most of the countries (Mexico, ${ }^{43}$ Peru, ${ }^{44}$ Argentina,${ }^{45}$ Brazil ${ }^{46}$ and Uruguay $^{47}$ ) have powers to regulate fees for some transfers products. For instance, authorities in Argentina and Mexico have mandated the elimination of fees for certain innovative transfer mechanisms to promote their adoption and generate competition in the payments market. In Chile, ${ }^{48}$ as part of the authorization process, the fees charged by low-value payment systems must be communicated to the relevant authorities; however, there are no clear criteria for their regulation.

\section{The likelihood of new payment platforms emerging, which can spur competition, is damped if there are no elements to promote interoperability between}

\footnotetext{
41 https://mibim.pe/tu-billetera-movil/quienes-nos-respaldan/

42 https://www.bcra.gob.ar/Noticias/PEI.asp

43 https://www.banxico.org. $\mathrm{mx} / \mathrm{marco}$-normativo/marco-juridico/ley-delbanco-de-mexico/\% 7B65E243F0-4E89-DE55-74AC-7AA890B13379\% 7D. pdf

44 https://www.bcrp.gob.pe/docs/Transparencia/Normas-Legales/Circulares/2016/circular-013-2016-bcrp.pdf

45 http://www.bcra.gob.ar/Pdfs/SistemasFinancierosYdePagos/MarcoLegalCompleto.pdf

${ }^{46}$ https://www.bcb.gov.br/content/financialstability/paymentssystem_docs/ Laws/Law 12865.pdf

${ }^{47}$ https://www.bcu.gub.uy/Circulares/seggci2159.pdf

${ }^{48} \mathrm{http}$ ///www.cronologiabancaria.cl/sbifweb/internet/archivos/ norma_44_1.pdf
} 
the platforms. In some jurisdictions, there are payment systems that coexist with platforms or payment agreements covering similar functionalities. This may affect the ability of participants to compete in the payments market if there is no interoperability between such arrangements. In the absence of interoperability, network effects generated by dominating platforms would disincentivize the emergence of new platforms and providers. Lack of interoperability would also affect financial viability of payments models, as participants would need to make additional investments to participate in each arrangement. This also affects the consumer as the coexistence of different payment arrangements and their lack of integration may discourage their use, particularly when the arrangements are not widely adopted, and users find that to make a payment to a counterparty they need to adhere to a new arrangement.

\section{Jurisdictions should promote system-level measures to homogenize the usage of payment systems.}

While interoperability may not be mandated as an initial requirement for payment systems, it is important that payment systems are designed with interoperability in mind. This means that their technical design and implementation should consider key design principles such as technological neutrality and that authorities set minimum operational features that allow for swift integration when interoperability is mandated. One of the measures that has been implemented in different jurisdictions to integrate payment arrangements and platforms is the adoption of standards for account identifiers, also called proxies. These countries (Argentina, ${ }^{49}$ Mexico, ${ }^{50}$ and Brazil ${ }^{51}$ ) seek to simplify the identification of accounts by using identifiers such as mobile phone numbers or assigning aliases designated by the users themselves. Other measures include adopting standards for payment mechanisms; for example, in Argentina the central bank has mandated that payments initiated by scanning a $\mathrm{QR}$ should be built under the same $\mathrm{QR}$ standard. At the same time, it is important to note that the concentration of all transfer operations

\footnotetext{
${ }^{49}$ http://www.bcra.gov.ar/MediosPago/Politica_Pagos.asp\#g

${ }^{50} \mathrm{https}$ // /www.banxico.org. $\mathrm{mx} / \mathrm{marco}$-normativo/normativa-emitida-por-el-banco-de-mexico/circular-3-2012/\% 7B4E0281A4-7AD8-1462BC79-7F2925F3171D\%7D.pdf

51 https://www.bcb.gov.br/en/financialstability/instantpayments
}

into a single payment system can create risks and raise participation requirements. The use of a single payment system at the national level in addition to incentivizing the concentration of risks increases participation costs, as the amount of resources at risk increases from including settlement of high-value payments.

\subsubsection{COMPETITION ASPECTS IN THE CARDS MARKET}

\section{Ownership and usage of cards has not followed suit to the usage of digital payments. While digital} payments usage and transactions have increased across LA-7, this has not been reflected in the cards market. Take-up of card payments by a larger part of the population has not increased among most of the LA-7 economies (Table 2). In general, ownership of credit and debit cards is consistent with usage behavior across most selected countries and segments. Data for ownership across segments show similar behavior to usage for most countries. The cases of Brazil and Peru are worth noting. For Brazil, on the debit card side while ownership remained constant, usage decreased. In the case of Peru, ownership has increased among most segments, but usage decreased, particularly for debit cards, which had the largest increase in ownership (Table 3).

The cards market involves more processes and participants than those required in the electronic transfers arrangements, so there are a greater number of interactions on which competition should be sought. The first type of participant is the acquirers, which are the entities responsible for making merchants adhere to card schemes to accept card payments. They have a contractual relation with merchants under which the acquirer sets fees, costs, technological, and connectivity requisites, among other business requirements. This provides the acquirer with the opportunity of establishing exclusivity agreements, demanding that the merchant accepts all payment instruments from a specific brand or issuer ('honor all cards' rule) and prohibiting the merchant from steering customers toward the use of specific payment instruments ('no surcharge' rule). Acquirers could also set contractual obligations such as tied-in sales of financial or 
TABLE 2: CREDIT AND DEBIT CARD OWNERSHIP AND USAGE

\begin{tabular}{|c|c|c|c|c|c|c|c|c|}
\hline & \multicolumn{2}{|c|}{$\begin{array}{l}\text { Gredit card } \\
\text { ownership } \\
(\% \text { age } 15+)\end{array}$} & \multicolumn{2}{|c|}{$\begin{array}{l}\text { Gredit card used in } \\
\text { the past year } \\
(\% \text { age } 15+)\end{array}$} & \multicolumn{2}{|c|}{$\begin{array}{l}\text { Debit card } \\
\text { ownership } \\
(\% \text { age } 15+)\end{array}$} & \multicolumn{2}{|c|}{$\begin{array}{l}\text { Debit card used to } \\
\text { make a purchase in } \\
\text { the past year } \\
(\% \text { age } 15+)\end{array}$} \\
\hline & 2014 & 2017 & 2014 & 2017 & 2014 & 2017 & 2014 & 2017 \\
\hline Argentina & $27 \%$ & $24 \%$ & $24 \$$ & $21 \%$ & $44 \%$ & $41 \%$ & $25 \%$ & $22 \%$ \\
\hline Brazil & $32 \%$ & $27 \%$ & $28 \%$ & $23 \%$ & $59 \%$ & $59 \%$ & $42 \%$ & $33 \%$ \\
\hline Chile & $28 \%$ & $30 \%$ & $23 \%$ & $25 \%$ & $54 \%$ & $60 \%$ & $40 \%$ & $47 \%$ \\
\hline Colombia & $14 \%$ & $14 \$$ & $12 \%$ & $11 \%$ & $30 \%$ & $26 \%$ & $18 \%$ & $12 \%$ \\
\hline Mexico & $18 \%$ & $10 \%$ & $11 \%$ & NA & $27 \%$ & $25 \%$ & $19 \%$ & $13 \%$ \\
\hline Peru & $12 \%$ & $12 \%$ & $10 \%$ & $9 \%$ & $21 \%$ & $28 \%$ & $12 \%$ & $9 \%$ \\
\hline Uruguay & $40 \%$ & $41 \%$ & $36 \%$ & $37 \%$ & $38 \%$ & $56 \%$ & $22 \%$ & $35 \%$ \\
\hline
\end{tabular}

Source: Findex.

TABLE 3: CREDIT AND DEBIT CARD OWNERSHIP BY SEGMENT

\begin{tabular}{|c|c|c|c|c|c|c|c|c|}
\hline & \multicolumn{2}{|c|}{$\begin{array}{c}\text { Gredit card } \\
\text { ownership, income, } \\
\text { poorest } 40 \% \\
(\% \text { age } 15+)\end{array}$} & \multicolumn{2}{|c|}{$\begin{array}{l}\text { Gredit card } \\
\text { ownership, income, } \\
\text { richest } 60 \% \\
(\% \text { age } 15+)\end{array}$} & \multicolumn{2}{|c|}{$\begin{array}{c}\text { Debit card } \\
\text { ownership, income, } \\
\text { poorest } 40 \% \\
(\% \text { age } 15+)\end{array}$} & \multicolumn{2}{|c|}{$\begin{array}{c}\text { Debit card } \\
\text { ownership, income, } \\
\text { richest } 60 \% \\
(\% \text { age } 15+)\end{array}$} \\
\hline & 2014 & 2017 & 2014 & 2017 & 2014 & 2017 & 2014 & 2017 \\
\hline Argentina & $14 \%$ & $14 \%$ & $35 \%$ & $30 \%$ & $36 \%$ & $28 \%$ & $50 \%$ & $50 \%$ \\
\hline Brazil & $20 \%$ & $16 \%$ & $40 \%$ & $35 \%$ & $42 \%$ & $44 \%$ & $71 \%$ & $70 \%$ \\
\hline Chile & $19 \%$ & $21 \%$ & $34 \%$ & $36 \%$ & $44 \%$ & $52 \%$ & $61 \%$ & $65 \%$ \\
\hline Colombia & $6 \%$ & $5 \%$ & $19 \%$ & $20 \%$ & $14 \%$ & $12 \%$ & $41 \%$ & $34 \%$ \\
\hline Mexico & $8 \%$ & $3 \%$ & $25 \%$ & $14 \%$ & $14 \%$ & $16 \%$ & $35 \%$ & $30 \%$ \\
\hline Peru & $5 \%$ & $4 \%$ & $16 \%$ & $17 \%$ & $9 \%$ & $17 \%$ & $30 \%$ & $35 \%$ \\
\hline Uruguay & $24 \%$ & $24 \%$ & $50 \%$ & $52 \%$ & $23 \%$ & $39 \%$ & $47 \%$ & $67 \%$ \\
\hline
\end{tabular}

Source: Findex.

technological services and they can also create partnerships with other acquirers to jointly negotiate contractual conditions with merchants.

The card issuers are in charge of providing cards to customers. They have a contractual relationship with the user of the card and set contractual obligations which can include clauses that limit competition, such as establishing additional costs or operational mechanisms for the user on acceptance networks that do not partner with the issuer. Brands dictate the operating, technological, and security standards of the scheme. As standard-setting bodies, brands influence the overall cost of adherence to card schemes, for which they could establish adoption of standards that are investment intensive and become prohibitive for new participants. They can also enter into exclusivity agreements with acquirers and issuers and limit acceptance of their brand to only a few participants.

\section{Payment processors are responsible for linking issuers and acquirers and carrying out clearing and settlement of card payments. The rules and procedures they set can be designed to carry out exclusionary practices by limiting the integration and interoperability of payment solutions. Recently, payment aggregators and gateways have been introduced in some ecosystems. Payment}


aggregators and gateways can enter into agreements with multiple acquirers and payment services providers and offer these different payment options to merchants on a single device or access point. This facilitates payments services provision for merchants and provide some level of interoperability

\section{The integration of different types of participants} with specific functions generates a more complex cost and fees structure than the one in the electronic transfers market. Merchant discount rates (MDRs) are charged to merchants by the acquirers, and additionally, merchants may be charged for the use and maintenance of the access points or point of sale (PoS). Acquirers pay an interchange fee to the issuers for the validation and approval of the transactions that circulate through the card network; in turn, both acquirers and issuers pay the brands for the licensing of the brand and the processors or clearing houses for the routing and settlement of the operations. Issuers charge their customers fees for granting and using the card itself.

\section{FIGURE 14: CARD SCHEMES}
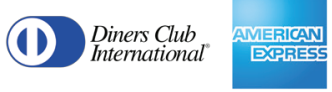

Licensor

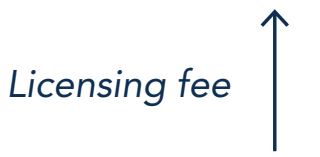

\section{Acquirer/lssuer}

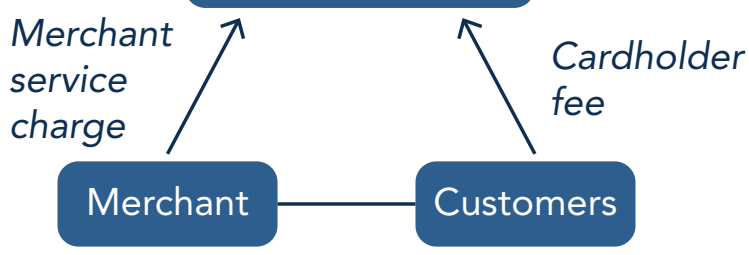

In LA-7, four-party schemes are predominant. The three- and four-party schemes coexist in the different jurisdictions; however, in most countries (Mexico, Argentina, Colombia, Uruguay, and Brazil) the four-party schemes are predominant, and their adoption has been promoted to increase competition - only in Chile the three-party scheme is the predominant one.

In general, barriers to entry and practices that limit competition are present in the cards market (Box 4). Competition authorities and financial authorities in Latin America have identified vertical agreements used to hamper competition and unilateral abuse of dominance through exclusionary practices and issued recommendations to reduce entry barriers and dissolve such practices in the cards market (Box 5). Recently, Peru's competition authority looked at whether vertical integration of the card market has harmful effects on competition. This is in light of the high fees charged by ${ }^{52}$ market participants and the low adoption of cards as a means of payment. Box 6 illustrates how authorities in other regions have taken measures to foster competition in the card segment.

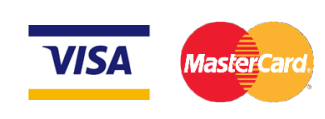

\section{Licensor}
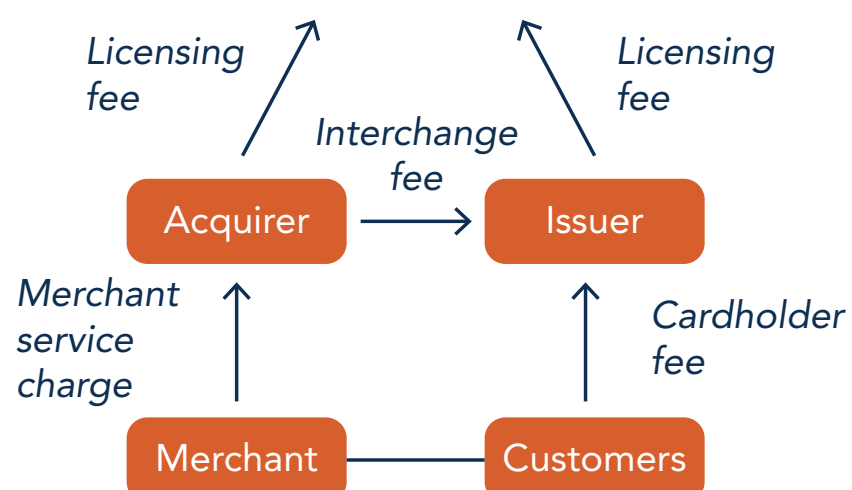

\footnotetext{
${ }^{52}$ https://www.indecopi.gob.pe/documents/51771/2610439/Sistemas + de + tarjetas + de+pago/
} 


\section{BOX 4: VERTICAL INTEGRATION IN THE CARDS MARKET}

Vertical integration consists of the participation of the same entity, in this case a bank, either individually or through corporate schemes, in the different stages of the processing cycle of a card transaction. However, when an entity or group of entities have dominant positions at one or more of these stages, they may impose barriers of entry on other competitors, hinder access to essential components or processes, and grant preferential conditions to partners.

The effects of exclusionary practices enabled by vertical integration can have pernicious effects on costs to users and merchants, which result in concentration of card payments among just a few participants, prices above competitive levels, and low adoption of cards usage and acceptance.

\section{The Wellink Report}

In 2001, the Minister of Finance of the Netherlands requested the President of the central bank to lead an investigation into tariff structures and infrastructure in the cards market.

Interbank had a dominant position on three key processes of card schemes: (a) it managed the PoS network, (b) it was the sole acquirer of the market, and (c) it carried out clearing of transactions between participants of the cards schemes. While it competed with banks and nonbanks on other services, its dominant position allowed to set high tariffs and technical specifications of PoS. Retailers' criticism of this advantageous position was especially severe.

The report developed by the central bank included the following recommendations:

- Promotion of customer choice among different fees structures

- Creation of a consulting group on payment services to discuss and assess structural changes to the payments market

- Enhancement of corporate governance of Interpay, which included independent experts on its supervisory board

- Improvement in transparency by including additional information on Interbank's external reports

- Contracting of networking services to the banks

- Creation within Interpay of a users' advisory group on the use of debit and prepaid cards

- Enhancement of corporate governance by including independent experts on Interpay's supervisory board.

The recommendations were implemented and Interpay does not act as acquirer of merchants.

Source: http://documents.worldbank.org/curated/en/839121469729131991/pdf/84076-REPLACEMENT-FILE-PUBLIC-Developing-comprehensive-national-retail-payments-strategy.pdf

\section{In all the jurisdictions, international brands have} the largest presence and market share. In all the jurisdictions, cards are issued by banks in association with international brands such as Mastercard, Visa, and American Express. In most jurisdictions, international brands, mainly Mastercard and Visa, hold the largest share of the market. ${ }^{53}$ In turn, only few countries established regulations for brands (Mexico), which include guaranteeing their affiliates' settlement activities and transparency measures,

\footnotetext{
3 In Brazil, in 2017, the market share for Visa was 47 percent and 43 percent for Mastercard. In Peru, in 2017, Visa had a share of 56 percent and Mastercard 28 percent. In Mexico, in 2019, the share was almost even, with 48 percent for Mastercard and 47 percent for Visa. In Argentina, in 2015, Visa share was 58 percent while Mastercard share was 11 percent. Source: Publicly available information.
}

such as reporting licensing and other membership costs, which are published by financial authorities.

\section{Measures have been implemented to lift restric- tions on acquiring services and promote interop- erability. Acquiring services have been opened to entities outside the banking sector. In some countries (Mexico, Brazil, and Uruguay ${ }^{54}$ ) acquisition services can be provided by other entities besides banks, while, in other countries (Colombia), they can only be provided by banks. Only some jurisdictions have implemented regulation so that acquiring is not limited to a single brand (Mexico and Uruguay). In

\footnotetext{
54 https://www.bcu.gub.uy/Acerca-de-BCU/Normativa/Documents/Recopi-
} lacion-de-Normas/Sistema-de-Pagos/libro_septimo.pdf}




\section{BOX 5: PRACTICES THAT LIMIT COMPETITION IN THE CARD MARKET IN LA-7}

In Latin America, discriminatory practices have been found in the card market, which are mainly associated with unintended effects of vertical integration and the concentration of this market among few participants. Below is a summary of the main findings regarding the imposition of high barriers to entry for new entrants in this market.

\section{Brazil}

In 2013, BCB, the Ministry of Justice, and the Ministry of Commerce found the following practices in the card market:

- Vertical integration carried out by banks with exclusivity agreements, both formal and informal

- Limitations for accessing merchant's sales information for entities outside of the vertical integration scheme, so that short-term financing for merchants is only offered by the entities that were part of the vertical integration scheme

- Refusal of integration of other acquirers in PoS

- Increases in the MDR for retailers who decide to establish relationships with acquirers outside vertically integrated organizations

- Cross-selling and tied-up sales.

Following the identification of such practices the Brazilian authorities generated cease-and-desist agreements. Until 2018, 15 agreements were generated with card market participants to eliminate anticompetitive practices.

\section{Mexico}

Both the competition authority in Mexico and the Bank of Mexico identified the following practices in the card market:

- Contractual restrictions on participation in services

- Vertical integration, concentrated in the six largest banks

- High costs, which inhibited low-value transactions

- Differentiated prices per participant.

In 2014, Mexico implemented a financial reform, which included concrete actions for the Bank of Mexico in conjunction with the Comisión Nacional de Banca y Valores (GNBV) to issue provisions to increase competition in the card market. In 2019, the Bank of Mexico reviewed interchange fees. As a result, participants set interchange fees at zero for some merchant segments (basic education and health, among others).

\section{Argentina}

In 2016, the competition authority in Argentina issued a series of pro-competitive recommendations in the card payment market, which were aimed at the central bank and the Ministry of Commerce and based on the detection of the following practices:

- Single acquirer for each card brand

- Vertical integration concentrated in the country's main banks

- Interest rates for merchants determined by vertically integrated entities.

As a result of the recommendations, banks divested from PRISMA, an entity through which vertical integration was implemented, and in addition the Argentine central bank promoted measures for multi-acquisition and the reduction of interchange fees.

\section{Ghile}

In 2017, the Chilean competition authority made a series of regulatory recommendations to promote competition in the cards market, which is vertically integrated around a single institution (Transbank) owned by banks. Based on the recommendations, the Chilean financial authorities have taken steps to promote competition, such as the possibility of issuing prepaid cards for nonbank institutions and non-restrictive access to create payment schemes, and in 2019 the Ministry of Finance put in place a plan to implement the adoption of a four-party model.

\section{Colombia}

Acquirer banks jointly determined the MDR for merchants, which allowed to set the MDR above competitive levels. Authorities prohibited the MDR from being jointly determined by acquirers, which resulted in a decrease of MDR for credit cards from 4.3 percent to 3.3 percent and from 2 percent to 1.7 percent for debit cards.

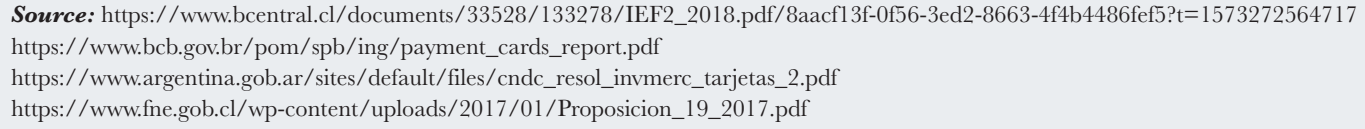




\section{BOX 6: PRACTICES TO PROMOTE COMPETITION IN CARD MARKETS}

\section{European Union}

In 2015, the European Union (EU) introduced regulation with the aim of increasing competition on the cards market:

- The regulation capped interchange fees for consumer credit and debit cards.

- It relaxed the 'Honor all cards' rule, allowing merchants to refuse to accept payment instruments to their convenience.

- The regulation relaxed the 'No surcharge' rule, merchants can steer customers to use specific payment instruments, if the cards are not subject to the interchange fee caps.
- Entities on the scheme should implement similar technical standards, which allows to implement interoperability.

- The processor of cards key functions, such as accounting and governance, should be independent of all other participants of a card scheme.

\section{United States}

The Durbin amendment was established by the 2010 Dodd-Frank Law. The Durbin amendment gives powers to the Federal Reserve to set caps on interchange fees. In 2011 interchange fees averaged US $\phi 44$, between 1 percent and 3 percent of the transaction amount, and the regulation capped fees on US\&21 plus 0.05 percent of the transaction amount. However, this was only applicable to banks with assets above US $\$ 10$ billion.

Source: https://ec.europa.eu/competition/sectors/financial_services/payments_en.html https://www.federalreserve.gov/paymentsystems/files/debitfees_costs_2011.pdf

other countries (Peru), acquiring can still be limited to a single brand, which is a result of vertical integration and affects competition between different card networks. Some countries have established regulation so that acquiring providers do not establish restrictions to merchants in terms of the entities where they will receive the resources from sales carried out with cards (Uruguay and Mexico). Brazil has promoted the interoperability between open and closed card networks through the implementation of bilateral contracts, such contracts are standardized to prevent the inclusion of clauses that promote discriminatory practices.

\section{Payment aggregators are entering the payments} market in selected jurisdictions, which has the potential to promote interoperability between card networks. In some jurisdictions, where payment aggregators have been regulated, these companies enter into contracts with several acquirers and generate economies of scale that allow them to offer lower costs to merchants, which promotes competition in the payments market and encourages access, especially for smaller merchants. Aggregators have gained relevance in increasing access to card payments, although there are jurisdictions that do not yet regulate them (Colombia).
Other measures to promote interoperability relate to the settlement of operations using clearinghouses. In Brazil, the settlement of card transactions takes place in a clearinghouse that is considered neutral (CIP), while in Mexico specific conditions have been established by authorities for the operation of clearinghouses, which include guidelines for the composition and independence of the board of directors, prohibitions on the conditional sale of services, and limits to volume-based discounts. Requirements have also been established for the interoperability of clearinghouses, including a ban on charging fees for linking different clearinghouses.

\section{Authorities have chosen to regulate the interchange fee to promote competition. Interchange fees are} obtained through the MDR charged to merchants. However, merchants have no power to influence the value of the interchange fee as this is set by the acquirer and the issuer. Authorities have chosen to cap the interchange fee to prevent prices being set above a competitive price level. Some countries do not regulate interchange fees (Peru, Colombia, and Chile) and in other countries (Brazil, Argentina, and Mexico) the authorities have chosen to regulate the interchange fee. In Mexico, the authorities have 
set caps on interchange fees and allow market participants to propose an interchange fee that goes below this cap. For the proposed fee they must provide a justification in terms of costs and how the new fee would help develop the card network; however, the authorities have the right to request more information on the proposed value, and, where appropriate, they are able to set the amount of the interchange fee. In Argentina, the authorities have proposed a cap on the value of the exchange fee, which gradually decreases year-on-year until 2021. However, some countries are cautious on the effects that limits to interchange fees might have on the market. In Chile, there are concerns about the short-term impact that the implementation of the new four-party model may have on card users and participants of card schemes, particularly as the loss of revenue from the application of interchange fees might be passed on to consumers through higher annual membership and card usage costs. ${ }^{55}$ Some authorities have fostered transparency regarding interchange fees and MDRs. Most jurisdictions have fostered cost-related transparency in the cards market, mainly with respect to MDRs and interchange fees, which are made available to the general public, so that merchants can assess the most convenient options.

2.1.4 OTHER COMPETITION RELATED ASPECTS BEYOND INFRASTRUCTURE ACCESS

Besides access to infrastructure, there are additional aspects that should be considered in the overall design of the payment systems deployment and that are relevant for competition. The role that different participants such as agents play in the provision of payment services and business models design, emerging models deployed by big techs, and regulatory arbitrage between incumbents and new market players are all additional aspects that can affect competition in the retail payments market.

\footnotetext{
55 https://www.bcentral.cl/c/document_library/get_file?uuid=5c7119bc-
} c922-bd66-f99b-8ea2b0f4f15f\&groupId=33528
The development of new business models and participants might have an impact on competition, but regulation for incumbents and new market players providing the same type of service differs substantially. Relaxed regulatory measures have positive effects on costs and convenience for users of payment services which can make new payments providers succeed, while on the other side regulation at early stages of technological development may hinder innovation. However, authorities must consider that this regulatory approach may lead to exponential growth of few market participants, allowing these participants to capture the market and impose practices that limit competition. Beyond market capture, technological capture is a risk that stems from underregulation, particularly for payment systems, as participants with dominant positions may develop technological infrastructure and standards that set barriers of entry and create challenges for interoperability.

\section{Big Tech participation in payments markets may} help develop the markets, but competition concerns may arise. Big Techs (for example, Alibaba, Amazon, Baidu, Apple, Google, Mercado Libre, and Tencent) that provide financial services have a small presence compared to banks across selected jurisdictions; for instance, outstanding credit provided by Mercado Libre in Argentina, Brazil, and Mexico had a value of US\$127 million dollars. ${ }^{56}$ However, Big Tech companies have the sophistication, technological resources, and direct interaction with users required to facilitate adoption of digital payments and exponentially increase their share of the payments market. Impact on payments infrastructure generated by Big Tech firms should be assessed from different angles. First, payments provide essential data that can be processed with additional information only available to these companies and that allow them to refine and strengthen their financial services offering; in this case, Big Techs can potentially provide incentives such as free payments just to access payment data, which would lead to concentration of the payments market, which in a later stage can result in price fixation practices. As Big Techs' share of the payment market increases, their closed payments infrastructure could become

\footnotetext{
56 https://www.bis.org/publ/work779.pdf
} 
the central infrastructure for exchanging payments, which without pro-competition practices could lead to lack of interoperability and access and participation restrictions. Interaction with users is another issue to consider; as Big Techs could provide the platform through which payments are initiated, they potentially can restrict what payment services are embedded within these interphases.

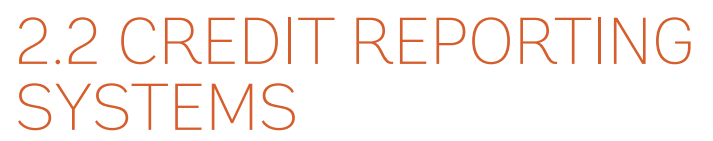

2.2.1 GENERAL ISSUES

A second important area where network externalities can generate competition issues is that of access to information. This section analyzes information networks in LA-7 to understand how they affect the provision of retail credit through aspects such as the vertical integration of the infrastructure, legal and regulatory barriers that might impede the sharing of comprehensive credit information, and behavioral aspects on information sharing arrangements. Evaluating the effects of credit information on competition has proven to be challenging for two main reasons: regulatory barriers and behavioral barriers, which are discussed in detail.

\section{Credit reporting addresses a fundamental problem} of credit markets: asymmetric information between borrowers and lenders, which may lead to adverse selection, credit rationing, and moral hazard problems. In competitive markets, the benefits of credit reporting activities are passed on to borrowers in the form of a lower cost of capital, which has a positive influence on productive investment spending. ${ }^{57}$ Efficient and comprehensive GRSs can lead to increased competition by reducing lenders' monopoly on credit information. Evidence suggests that, in countries with both positive and negative CRS, as compared to GRS covering only negative data, credit availability is higher and default rates are lower. The availability of relevant and affordable credit information also depends on the efficiency of the credit reporting service providers, the barriers to data access,

\footnotetext{
57 For more information on how credit reporting can lower the cost of capital, see Jappelli and Pagano (2000); Padilla and Pagano (1997); Pagano and Jappelli (1993).
}

and the capacity to share data in the form of suitable and affordable products based on reliable and accurate data to all the creditors in the market.

\section{The General Principles for Gredit Reporting} (GPCR) issued by the World Bank in 2011 recognizes that GRSs support robust and competitive credit markets. The GPCR under its overarching public policy objectives for credit reporting states that CRS should effectively support the sound and fair extension of credit in an economy as the foundation for robust and competitive credit markets. In doing so, CRSs should be safe and efficient and fully supportive of data subjects and consumer rights.

In a competitive market for credit reporting, CRSs are expected to compete by differentiating their services, improving the quality of their data, and offering a range of value-added services. Under these conditions, CRS services should translate into higher efficiency and better access in the adjacent credit markets. In practice, competition in credit reporting may be limited by a series of markets imperfections or barriers to entry. Among these are inadequate regulation, concentration in credit or credit reporting, vertical integration, scale or network economies, or behavioral barriers like discrimination or refusal to participate in the CRS. Provided that access to a large volume or variety of data is important to be able to compete in the market, the collection of data may result in entry barriers when new entrants are unable either to collect the data or to buy access to the same kind of data, in terms of volume and/or variety, as established by CRSs. This is especially true for new fintechs trying to develop value-added services using structured data held in credit bureaus. But it is also the case for CRS vertical markets (for example, microfinance, cooperatives, retailers, or banks) that are not able to access credit information from other data providers.

\subsubsection{REGULATORY BARRIERS}

GRSs are typically regulated by a myriad of rules that balance the need for information sharing under limited and specific circumstances with rules related to data protection and privacy. Regulation of credit reporting activities usually focuses on 
registering or licensing of credit reporting service providers, imposing responsibility for data accuracy, collection, and disclosure; consumers having access to their information and being able to have erroneous information corrected; compliance monitoring; and enforcement. There is however no consensus on what constitutes an adequate legal and regulatory framework for credit reporting as there is a natural tension between the objectives of having access to broader sources of information for enhanced credit reporting and the interest in preserving individual privacy. More recently, due to additional entrants in the market, competition authorities are also ruling to some extent the information market and fair access to information by all relevant market participants. In Brazil, for example, the Conselho Administrativo de Defesa Econômica (CADE) authorized the establishment of Gestora de Inteligencia de Credito (GIC) participated by the five largest domestic banks as a credit bureau subject to a limitation on the decision-making power of the five banks in the GIC. The main rationale of the intervention was to mitigate the risk that the participating banks could benefit from access to their customers' information or that this could become a barrier to entry for new competing banks. ${ }^{58}$
There is no standard on the legal basis for the provision of credit information services (Figure 15). Yet if such a framework is not properly designed, it can create unjustified barriers to entry to potential new market players. Also, to protect privacy rights, the legal framework might require data providers and service providers to collect data on them and to prove the provision of consent on every single case which, apart from being costly, would be overly cumbersome and undermine the usefulness of the data if no technology is available to effectively allow this proofing. Through adequate regulation, some key aspects affecting efficiency of the systems can be addressed such as (a) ensuring competitors' fair access to credit reporting services, especially when ownership structure of credit reporting service providers does not provide incentives for the latter to do so, or (b) ensuring that certain standards (for example, data quality) are equally applicable to all participants in the system. Therefore, decisions to exclude participants from a CRS - particularly in countries where there is only one CRS - should be based on capacity to supply quality information on a systematic basis and ensure data confidentiality of data received and security of data and systems connected to the network.

\section{FIGURE 15: TYPE OF LAWS REGULATING CRSS}

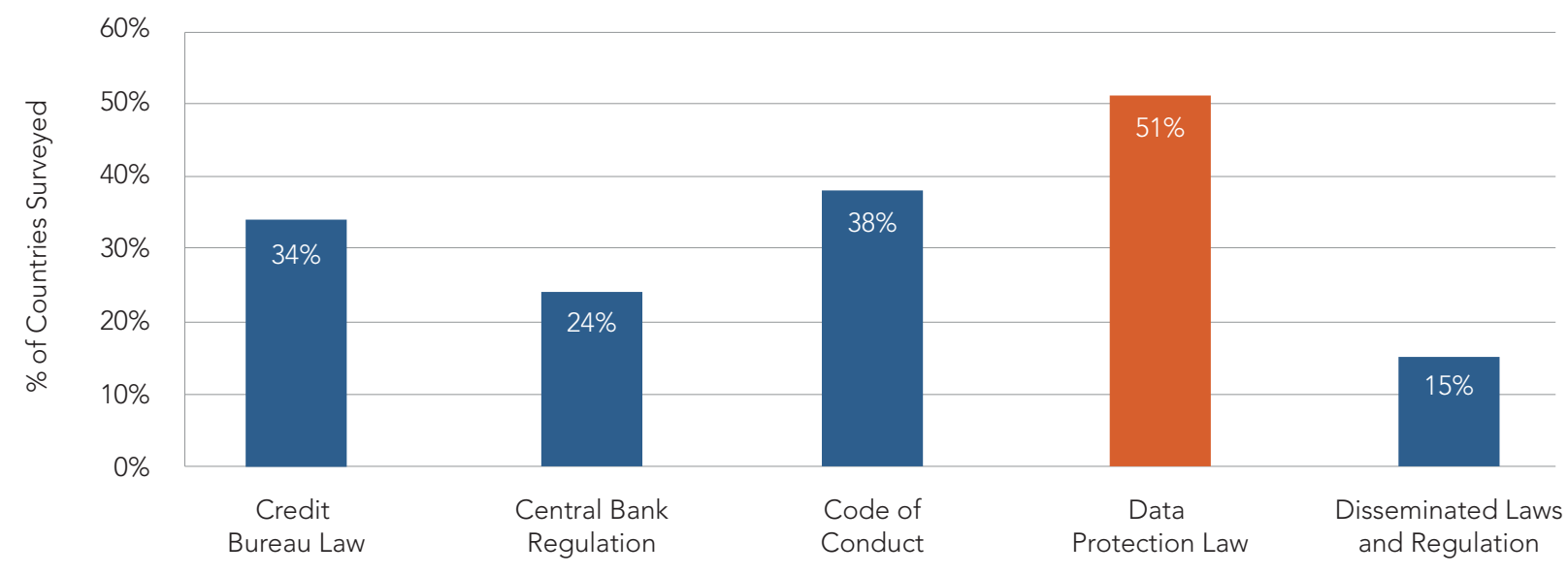

Source: Own elaboration based on existing laws and regulations worldwide 2015.

\footnotetext{
${ }^{58}$ The GIC is participated by Banco do Brasil SA, Caixa Econômica Federal, Itaú Unibanco Holding SA, Banco Bradesco SA and Banco Santander Brasil SA. For additional information, see CADE Merger Case No. 08700.002792/2016-47 (Applicants: Banco do Brasil, Banco Bradesco, Caixa Econômica Federal, Banco Itaú, and Banco Santander).
} 


\section{GPGR 4 calls for a nondiscriminatory approach} to system participation. In this regard, data supply and data access should be established in a fair manner, responding to impartial rules regardless of the nature of the participants. In principle, all active users of data for lending purposes should be allowed to access credit reporting databases. Policy objectives and legal mandates as well as the nature of the credit registries make this type of infrastructure limited in terms of access to regulated entities to fulfill supervisory rules regarding credit risk management. However, this is not considered a discriminatory practice as the common factor to determine access is related to the mandate of the supervisory authority to effectively conduct its supervision. Participation in a credit bureau is typically voluntary and based on three key aspects: (a) willingness to participate in the system by the credit provider and the CRS, (b) capacity of the credit provider to submit data on a systematic basis of sufficient quality, and (c) ability to meet compliance requirements in an affordable manner. However, under certain circumstances, credit information exchange between competitors can constitute a violation of competition law and restrict competition in the credit market. Some CRS arrangements include the so-called 'closed user group' of information sharing by which banks participants of such a group only share positive and negative information with the members of the group while the negative information is shared with the broader participants to the CRS. ${ }^{59}$
GRS regulation does not typically call for interoperability between GRSs although it could contribute to reduce data fragmentation. In LA-7, CRSs are frequently developed to attend to sector needs, which leads to vertical market integration. The composition of data providers in each of the CRSs in the respective jurisdictions shows such vertical market integration and how CRSs are built as a strategic competitive tool leading to data fragmentation. In general, there is no interoperability between the different CRSs, but they rather tend to develop their respective data formats, software, and product design with no collaboration with other CRSs. Regulation includes provisions to ensure that creditors are able to submit data to any type of CRS without the need to conduct additional extraordinary efforts to participate in more than one CRS. Table 4 shows the type of CRSs in each LA-7 country and how they are mostly serving one credit market or another. Some CRSs facilitate the exchange of information between creditors of different sectors while others serve specifically one sector (for example, cooperatives or microfinance institutions [MFIs]). In general, those that include banks as their main data provider tend to include additional data from other sectors including nonfinancial institutions such as retailers or telecommunication service providers. However, there are situations where even within the GRS, internal operational rules allow the sharing of certain data items only between a reduced number of data providers. This practice is known as a closed user group.

\section{TABLE 4: CRS IN LA-7}

\begin{tabular}{|c|c|c|c|c|}
\hline & Banks & Retailers & Cooperatives & MFIs \\
\hline Argentina & Veraz & Nosis & & \\
\hline Brazil & Serasa Experian/GIC & Boa Vista & & \\
\hline Chile & Dicom/SINACOFI & $\begin{array}{l}\text { Camara de COmer- } \\
\text { cio de Chile (CCS) } \\
\text { Databusiness }\end{array}$ & & \\
\hline Colombia & CIFIN-Transunion & Experian & & Experian \\
\hline Mexico & Buró de Crédito & Circulo de Crédito & & \\
\hline Peru & Equifax & Experian & & Experian \\
\hline Uruguay & Equifax & & Infocred & \\
\hline
\end{tabular}

Source: Own elaboration.

\footnotetext{
59 This practice is not observed in Argentina, Mexico, or Colombia but is present in Chile, Paraguay, and Uruguay.
} 


\section{Information exchanges among competitors} increase transparency in the market, which can lead to efficiency enhancing benefits but may also present competition risks. As highlighted by the GPCR, sharing of information enables certain markets to function effectively such as in retail credit markets where the sharing of data on the creditworthiness of borrowers among banks results in better access to credit for good customers. The potential for anticompetitive effects depends on a number of key factors, such as the type of information exchanged and the structural characteristics of the market involved. There are some cases where the credit registries share information with all credit bureaus which is the case in Argentina and Peru. The information included under the Central de Deudores operated by the Banco Central de la República Argentina (BCRA) is shared with the credit bureaus; however, such information is not as detailed as the information collected from lenders by credit bureaus or there are limitations to access such information by lenders. Some of those restrictions include the need for an existing loan relationship between the borrower and the lender or a loan application. In Mexico, the Credit Information Companies Law introduced the mandatory exchange of credit information between the two existing credit bureaus to provide comprehensive credit reports to consumers and avoid data fragmentation. According to Spanish law, sharing information between competitors is considered a practice that restricts competition; however, such exchange on a systematic basis can be authorized by the competition authority if it contributes to foster economic development, fosters provision of services and products, and enables better terms and conditions to consumers.
In 2005 the Spanish competition authority ruled that the Registro de Aceptaciones Impagadas (RAI) operated by the Centro de Cooperacion Interbancaria violated the competition law. ${ }^{60}$ The ruling was based on the nature of the RAI file which was considered as 'irreplaceable' in the credit information market and there were no alternatives for service providers to offer valuable credit information services without accessing such data. On another note, the competition authority in Chile ruled on the obligations that the data controller of the Boletin de Informaciones Comerciales (BIC) file had with regard to the accuracy of data (Box 7).

\section{Privacy is often cited as one of the regulatory barriers to information sharing between competitors although bank secrecy provisions are far more restrictive than data protection rules. It is true that} the provision of credit information to lenders requires a balanced approach between access to information and consumers regarding their privacy. In practice, however, the rule itself is not an impediment as data protection laws allow information sharing and provide a number of grounds for data processing including (a) compliance with existing laws, (b) contractual obligations, (c) consumer consent, (d) public interest, and (e) vital interests of the consumer. The

\footnotetext{
${ }^{60}$ For additional information, please see Resolución Expediente A335/03/ RAI/CCI 2005. The resolution discussed whether the RAI is considered under the practices that restrict competition under article 1 of the law but could be subject to an authorization to operate issued by the competition authority or there is no need for such authorization because sharing credit information between competitors does not fall under the practices that restrict competition included in article 1 of the Ley de Defensa de la Competencia.
}

\section{BOX 7: CHILE: CCS MONOPOLISTIC PRACTICES THROUGH THE BIC FILE}

The Supreme Decree 950 of 1928 established a legal monopoly regarding data collection of debts toward the CCS. Based on such decree, all notaries, courts, property registrars, other government institutions, and banks and financial institutions should submit information of unpaid letters of credit and bills of exchange to the CCS. The information included was initially distributed in a paperbased publication and each correction had inherent costs.
These costs had to be assumed by the debtors; otherwise, information was not corrected in the BIC. The competition authority ruled that the CCS conducted monopolistic practices with regard to the processing and further distribution of information included in the BIC. The competition authority ruled that the CCS could no longer impose this cost to debtors as it was their responsibility to maintain the accuracy of information in their files.

Source: Tribunal de Defensa de la Libre Competencia, Chile July 11, 2007. 
manner the law is implemented might cause barriers to information sharing as well as how the rule is interpreted by the credit providers. In Brazil, for example, the cost of compliance impeded the submission of positive data to the CRS (Box 8), while in Chile, the interpretation of the data protection law concerning positive data sharing impeded CRSs to move from a negative data sharing environment to a comprehensive data sharing. By contrast, in Argentina, credit information is considered an asset of unrestricted access and available to all credit providers although in practice this is only true for data held under the credit registry operated by the BCRA. In Peru, the law on credit bureaus allows the sharing of information with no need for consumer consent although subject to bank secrecy restrictions. In Colombia, the law on 'habeas data' regulates information sharing agreements between credit providers but leaves broad space to CRSs to determine the extent of information sharing arrangements between competitors.

\section{Limits on the participation of foreign investors in a GRS can also contribute to practices that limit competition in the information sharing market.} In principle, regulation does not impede any international investor from developing a CRS or imposing excessive requirements for the provision of the service. There are no limitations to the participation of foreign companies in the laws regarding credit information in Argentina, Colombia, Mexico, Peru, Uruguay, or Paraguay. In Mexico, we observe that there have been several attempts by Equifax and Experian to enter the market and they never obtained a license to operate by the competent authority, the GNBV. It should be noted that one of the CRSs operating in Mexico is owned by the banks and the other one by the retailers which are the largest credit providers. This reason might prevent the entry of foreign credit bureaus that require data from the credit providers to make their business sustainable.

\subsubsection{BEHAVIORAL BARRIERS}

\section{Business decisions on GRS models, product development, and information flows might be hampered by conflicting interests between the objective of the GRS and shareholders' specific} interests. The main objective of a CRS is to enable the flow of reliable and timely information relevant to conduct credit risk assessments of clients (both individuals and legal entities). Typically, private credit information sharing networks were created as the benefits of sharing data were greater to those of not sharing. Retailers in the textile sector started sharing information about their risky customers to avoid bad behavior related to nonpayment. This same practice was extended to other sectors such as furniture, equipment, and later credit cards service providers which was when CRSs really boomed. Though all voluntary participants to the information sharing network were really willing to share data about negative behavior of their clients (nonpayment or late payment), they were not so inclined to

\section{BOX 8: IMPLEMENTATION OF PRIVACY RULES IN BRAZIL}

In 2016, credit bureaus had negative data of nonpayment covering 58.8 million individuals and positive credit information showing a good payment history on only 5.5 million individuals due to legal constraints. To share positive credit information, creditors needed to collect borrowers' consent before sharing data to the CRS; moreover, they needed to inform through certified postal services such data distribution. Due to these requirements, relevant information has been shared only under restricted information sharing scenarios, which led to higher cost for creditors wishing to enter the market, thus raising the cost of credit and restricting the number of consumers

Source: Brazil FCI Policy Note, World Bank 2018. receiving credit. The reform consists of mandatory contribution of negative and positive credit events, on an opt-out basis. It will enable financial institutions to access the data on borrowers' credit scores without the need for explicit borrower consent, thereby significantly broadening the scope of the credit bureaus, which currently cover merely 5 percent of all bank customers. The reform aims at making a relevant contribution to reducing the cost of credit by improving financial institutions' and other nonfinancial companies' ability to determine the creditworthiness of customers. 
share data about positive behavior of their clients (on-time payment, amount of product served to the client, and so on) due to fear of losing those good clients.

However, given that information (mostly positive data) is considered a valuable asset for credit providers, in countries where CRSs are owned by banks, bank representatives may favor measures that limit the availability of positive information for value-added services to soften competition from other entities in the credit market. In principle, regulation does not impose requirements on the provision of the service and therefore it is left to the management and board of directors of each CRS to decide the types of services offered and determine prices and rules to access the service. Some anticompetitive behavioral practices from CRSs include the following: (a) provide inefficient access to non-owner competitors and (b) in vertical markets where CRSs are built around those markets, impede access to other GRSs. As an example, a common practice in the 1990s in CRSs was the existence of exclusivity contracts between CRSs and some credit providers so that they only submitted data to one CRS.

\section{FIGURE 16:}

\section{OWNERSHIP STRUCTURE OF CRS}

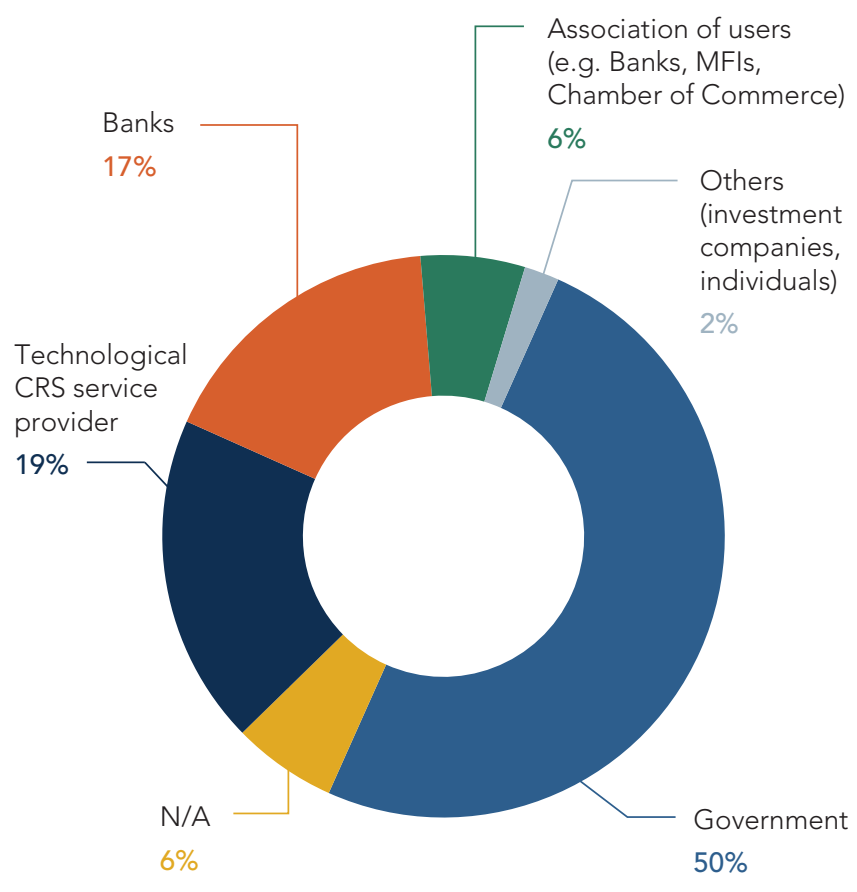

Source: Own elaboration using Doing Business data including 165 economies, 2015.
Behavioral barriers to access credit information is typically present when there is market concentration. In Mexico, for instance, the competition authority (Comisión Federal de Competencia Económica, COFECE) conducted a study in 2014 stating that the credit market comprising the five largest banks was concentrated. ${ }^{61}$ This market concentration was also present with regard to the infrastructure supporting the market, ${ }^{62}$ which affects the service delivery to some credit providers. The negotiating power of banks as shareholders in a CRS implies that they will treat the agency as a strategic partner to advance their interests in the credit and banking businesses. As a consequence of this situation, small banks face information limitations that impede effective competition which is more acute when these banks are serving small and medium enterprises (SMEs), as the provision of value-added services for SME loans is extremely limited when compared to value-added services for consumer loans. ${ }^{63}$ This is the result of the limited capacity of the administration of a CRS to act independently. In Colombia, where information is widely available in all market segments from consumer credit to SMEs and corporate lending, it is also the case that CRSs are controlled by international technological partners who hold the majority of the shares of the institution and not by banks or other creditors. ${ }^{64}$ In Argentina, although information is broadly available through the credit registry to all credit providers, there are also CRSs that operate under a limited number of creditors, which contributes to data fragmentation.

The type of information and data can affect behavior but evidence is mixed. On the one hand, in countries with both positive and negative information sharing mechanisms (for example, through credit bureaus), as compared to mechanisms covering only negative data, credit availability is higher and default rates are lower. ${ }^{65}$ On the other hand, Padilla and Pagano (2000) conclude that sharing more detailed information can reduce the

\footnotetext{
${ }^{61}$ https://www.cofece.mx/cofece/images/Estudios/ResumenEjecutivo26-09-14.pdf\#pdf

${ }^{62}$ The banks participating in Buró de Crédito represent 84 percent of the consumer and housing credit market in Mexico provided by regulated entities while Circulo de Crédito is owned by retailers.

${ }^{63}$ For more information, please see COFECE (2014).

${ }^{64}$ There are three CRSs in Colombia: Experian, Transunion, and Procrédito.

65 Barron and Staten 2003; Powell et al. 2004.
} 
disciplinary effect of the information exchange and that borrowers' incentives to perform may be greater when lenders only disclose past defaults than when they share all their information. GPCR 1 calls for sharing comprehensive data, including positive information. Figure 17 shows that positive data sharing is more prevalent among banks and financial institutions than any other type of data provider. Positive data are shared in CRSs operating in Argentina, Colombia, Mexico, and to some extent Peru. Brazil recently introduced a reform to ease the process of capturing positive data and Chile only collects negative data.

\section{FIGURE 17:}

\section{POSITIVE DATA SHARING IN CRS}

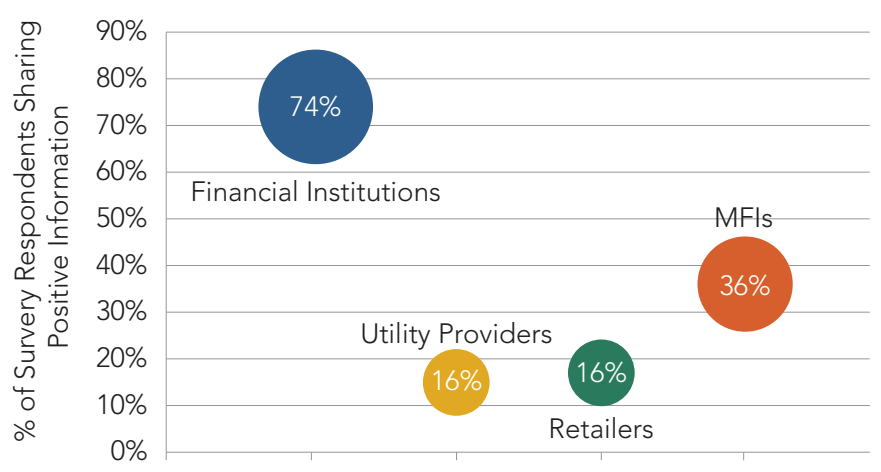

Source: Own elaboration using Doing Business data, 2015.

\section{Other aspects that can lead to anticompetitive} behavior are actions taken by the GRS with regard to the different types of creditors. Given that CRSs rely on mutual information sharing - reciprocity principleprices are typically structured based on the volume of information submitted to the CRS. Discounts to access credit reports or value-added services will be given to those that provide the largest volumes of data which would typically be the largest participants in the market. This is the case for CRSs operating in Argentina, Brazil, Colombia, Mexico, and Peru and some in Paraguay and Uruguay.

\subsubsection{OTHER INFORMATIONAL PRACTICES THAT MIGHT AFFECT COMPETITION IN THE RETAIL BANKING MARKET}

Big Tech companies (for example, Alibaba, Amazon, Baidu, Apple, Google, Mercado Libre, and Tencent) have been moving into a wide range of financial services at a rapid pace. They rely on the processing of an incredibly amount of data that they collect and monitor on a daily basis and regarding purchases, habits, and interactions with others. The Financial Stability Board (FSB) showed that some of these firms are already providing lending and short-term credit in emerging markets which is the case of Mercado Crédito focusing on small loans to consumer and SMEs in Latin America. Firms in some jurisdictions offer loans to merchants and small businesses that transact via their retail platforms. By harnessing their large existing customer bases and technological infrastructure, Big Techs are able to distribute loans without the costs associated with operating a branch network. ${ }^{66}$ Advanced data analytics allows Big Tech firms to leverage large amounts of data from e-commerce and social networks to compensate for a lack of credit history, collateral, and other factors that typically limit the provision of consumer loans. In Mexico, regulatory measures included through the implementation of the Fintech Law could provide a level playing field between Big Techs and incumbents with regard to their informational rents in relation to the provision of credit to consumers and SMEs. However, since these types of companies are not regulated and often operate in more than one jurisdiction, it might be worth exploring trade-offs between financial stability, competition, and data protection. In this context, greater cooperation between data protection, financial, and competition authorities might be necessary to address competition impact in the credit market.

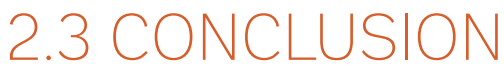

In most LA-7 countries, competition authorities and central banks have taken a more proactive approach to regulating payments markets to promote competition, but exclusionary practices and other anti-competition practices enabled by vertical integration still pose a significant challenge across the region. In many cases across LA-7 countries, participants of payments markets have created vertical structures that allow them to capture payments-related revenue in detriment of competition and development

${ }^{66}$ FSB 2019. 
of the payments market. In some jurisdictions and for some markets, the authorities have acted upon this, but analysis of anti-competition practices enabled by vertical integration must be extended to all types of digital payments instruments and payments infrastructures. Authorities across jurisdictions must take a more proactive approach with regard to competition, including constantly reassessing the effects of competition policies and establishing relevant metrics and indicators that allow monitoring competition conditions on a regular basis. This analysis should include how policy responses have translated in net benefits for merchants and customers or if the impact of competition policies on banks, such as revenue loss, is being passed on to users and participants through other mechanisms.

\section{LA-7 economies are adapting their legal frameworks} and payment systems and arrangements to new technologies, providers, and business models, but conditions still favor bank-led models. Ideally, the new frameworks would reduce market concentration and put pressure on incumbents to deliver enhanced payment instruments to customers. However, the authorities still need to balance fair and nondiscriminatory access to payment systems while keeping the systems robust. For this, it is important that the authorities identify which access and participation requirements are vital for keeping a resilient system and what requirements are incentivizing exclusionary practices. In this regard, the authorities need to constantly review vulnerabilities and keep a flexible regulatory framework that allows to recalibrate participation requirements as risk conditions evolve. When revisiting competition assessments and frameworks, competition between payment instruments is an area that regulators must focus on, as instant payments schemes, digitalization of cards, and the entry of payments aggregators and gateways are increasing competition between different types of retail payment instruments. In this regard, the authorities must be aware of market participants' incentives to favor usage of a specific payment instrument and how this can aggravate exclusion and other anti-competition practices.

Efficient and competitive credit allocation in LA-7 may have been undermined by poor design and weak oversight mechanisms. Efficient CRSs that collect comprehensive data from all relevant credit sources in the market and develop products and services that meet user needs, with clear and fair rules regarding access, can contribute to competitive credit markets. Yet, GRSs in LA-7 have traditionally focused on sharing mostly negative information of clients' nonpayment. This is mostly the result of the lack of adequate regulation regarding data sharing but weak oversight is likely to play a role as well. Although increased competition is cited as a key objective of CRS reforms, oversight mechanisms pursuing such objectives in LA-7 are not developed. Regardless of the type of authorities that oversee credit reporting, there is no clear oversight function in this area. With the exception of Mexico, the negative consequences of vertical markets for credit reporting are not typically addressed by the financial sector authorities nor by the competition authorities. In Argentina, Colombia, and Uruguay, CRSs are monitored only from a data protection angle. In Peru, oversight of CRSs is built around consumer protection only, with no consideration for other objectives such as competition or financial stability.

There is not much coordination between competition authorities and financial sector authorities with regard to credit reporting although a more active role by the competition authorities in this area is observed. The role of COFECE of Mexico in conducting research in this space and collaborating with the Bank of Mexico and CNBV is one example; others include CADE of Brazil approving the establishment of a CRS by the five largest banks in the country and the Tribunal de Defensa de la Competencia of Chile in relation to sharing information from the Boletin de Informacion Comercial with other credit bureaus. Going forward, it is important that the authorities start working together to understand the potential impact of Big Techs in the provision of financial services. Given their dominant position in the market as e-commerce platforms or data engines, these companies gather large amount of consumer data that enable them to offer financial products and services to consumers. While this trend could benefit consumers, it might also come with unintended negative consequences for the credit markets, which warrants scrutiny. 



\section{CHAPTER 3:}

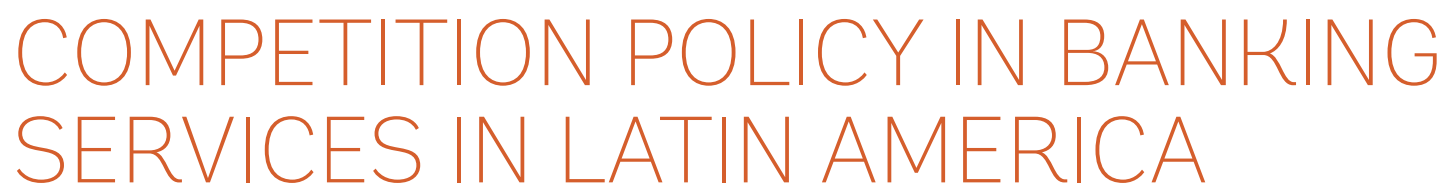

This chapter discusses the state of competition law enforcement and advocacy initiatives in the banking sector in selected Latin American countries. Based on a novel survey rolled out in the LA-7 economies, ${ }^{67}$ it provides a comparative analysis of competition policy implementation in retail banking in the region. The mixed track record of competition law application in Latin America in this sector is put into the context of the comparatively rich international experience. This chapter discusses features of the institutional setup, scope of mandates, and recent track record of enforcement actions and advocacy initiatives. The discussion emphasizes instances of cooperation between competition authorities and banking regulators. Pro-competition design of sector regulation is discussed only in the context of selected advocacy initiatives by competition authorities.

${ }^{67}$ The survey was rolled out in 2019 to competition authorities and/or banking regulators from LA-7. 


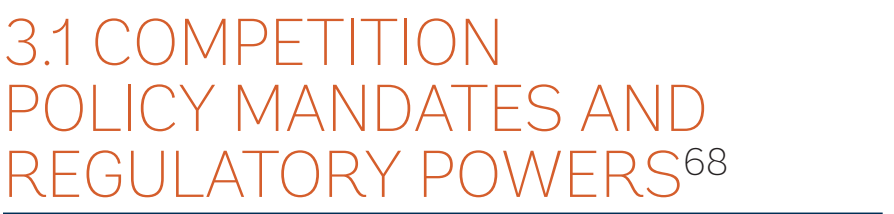

In LA-7, the competition authorities' mandate generally extends to the banking sector. ${ }^{69} \mathrm{~A}$ competition law ${ }^{70}$ that applies to all sectors provides stability and is less prone to industry capture than selective competition rules. ${ }^{71}$ Implementation of competition law in the banking sector by the national cross-sectoral competition authority is generally considered desirable as it leverages specialization in competition enforcement, prevents agency conflict, and avoids the coordination costs of overlapping jurisdictions. ${ }^{72}$ Enforcement of competition law by an independent authority should be shielded from political influence and should also be conducted separately from prudential analysis. Interinstitutional mechanisms are then essential to achieve the proper balance between the regulatory objectives and make available detailed industry knowledge to the competition authority. Based on the survey conducted for this paper, in all but one of the countries, the authority in charge of enforcing the economy-wide competition law also has the mandate to enforce the law in the banking sector. ${ }^{73}$ The

\footnotetext{
${ }^{68}$ While the focus of this report is on retail banking services, the legal framework does not always distinguish regulatory and competition competencies between the banking and the broader financial services sector. This chapter therefore covers broader financial services.

69 For a discussion, see World Bank 2016a.

${ }^{70}$ Competition law applies across all sectors and to all public and private economic agents and includes provisions that prohibit anticompetitive agreements and abuse of dominance, merger review, and advocacy to tackle government interventions that could restrict competition. Effective enforcement rests on elements that include a primary legal and policy framework, an adequate institutional structure and availability of technical and financial resources, and specific implementing rules, guidelines, capacities, and skills to effectively exercise the powers to prevent, investigate, and prosecute anticompetitive practices, assess mergers, and carry out market studies or other advocacy initiatives. Among others, the operational framework requires guaranteeing institutional independence particularly regarding the budgetary and administrative independence of the competition authority.

${ }^{71}$ See Becker 1976, 1983; Laffont and Tirole 1991; Posner 1988, 1974; and Stigler 1971.

72 For discussion, see Carletti and Hartmann 2003; Claessens 2009; ICN 2005; OECD 2011.

73 According to the following laws and regulations: (a) Argentina: Law 27442 and Law 24.144; (b) Brazil: Law 12,529/11 and Law 4595/64; (c) Chile: Decree Law 211 and Decree Law 3; (d) Colombia: Law 1340 and Law 155; (e) Mexico: Ley Federal de Competencia Economica; (f) Peru: Supreme Decree 030-2019-PCM, Law 26702, and Urgency Decree 013-2019; and (g) Uruguay: Law 18.159.
}

only exception is Uruguay, where the central bank enforces the competition law.

\section{LA-7 countries have solid competition legal} frameworks in place and their agencies are among the region's most mature. All jurisdictions covered in this study have had competition law in place for over 20 years. Most of them have passed second- and third-generation reforms. They are aligned with international standards for the evaluation of potential anticompetitive conduct within a well-established economic rationale framework to promote efficiency. The design of merger review and the application of due process standards are also generally in line with good practices. In this respect, the competition legal frameworks of these economies should generally be well suited to address competition concerns in the banking sector.

\section{Competition authorities in LA-7 have the essential enforcement and application capacities needed to investigate anticompetitive practices in the banking sector. Given the secretive nature of anticompetitive} practices, such as price agreements, competition authorities require specific investigative tools to uncover such conduct. Competition authorities in all countries covered by the survey have the necessary powers to conduct unannounced visits at the premises of alleged cartel members (dawn raids), require individuals under investigation to be interviewed, and issue compulsory request of information (see Table 5). In addition, most of the countries, except Argentina and Uruguay, have invested into sophisticated IT forensic capabilities to uncover evidence from digital sources. As of 2019, Brazil, Chile, Colombia, Mexico, and Peru had all detected several secretive hard-core cartels per year with sophisticated investigative instruments. Authorities in LA-7 are therefore generally well equipped to uncover and deter anticompetitive conduct in the banking sector. International experience suggests that proactive investigative tools are critical to uncover anticompetitive conduct in the financial sector. For example, empirical screening tests triggered the allegations of the LIBOR conspiracy (see Box 8).

\section{Major cartels have been uncovered with leniency programs in LA-7, but the countries have not yet}


TABLE 5: COMPETITION ENFORCEMENT TOOLS IN LATIN AMERICA

\begin{tabular}{|c|c|c|c|c|c|c|c|}
\hline & Argentina & Brazil & Ghile & Colombia & Mexico & Peru & Uruguay \\
\hline Dawn raids & Yes & Yes & Yes & Yes & Yes & Yes & No \\
\hline Interviews & Yes & Yes & Yes & Yes & Yes & Yes & Yes \\
\hline $\begin{array}{l}\text { Compulsory requests of } \\
\text { information }\end{array}$ & Yes & Yes & Yes & Yes & Yes & Yes & Yes \\
\hline IT forensics & No & Yes & Yes & Yes & Yes & Yes & No \\
\hline Other & - & - & $\begin{array}{l}\text { Wire-tap- } \\
\text { ping } \\
\text { collusion } \\
\text { cases }\end{array}$ & - & - & - & - \\
\hline Leniency programs & Yes (partial) & Yes & Yes & Yes & Yes & Yes & Yes \\
\hline
\end{tabular}

seen leniency applications in the banking sector. ${ }^{74}$ Programs in which cartel members can come forward to reveal the agreement in exchange for exemption from fines (leniency programs) have proven critical to destabilize and reveal cartel agreements in Latin America. ${ }^{75}$ All LA-7 economies have leniency programs in place, and except for Uruguay and Argentina, all countries have succeeded in attracting numerous leniency applicants. However, to date, there has only been one (unconfirmed) leniency application in the financial sector.

\section{Competition authorities in LA-7 have increasingly gained institutional independence, de jure and/} or de facto. ${ }^{76}$ In 2013, Mexico granted its competition authority the highest institutional independence with a constitutional reform. Brazil's competition authority enjoys 'federal autarky' since 2012. Chile's current competition policy institutional setup was created in 2003 and features an independent quasi-judicial competition tribunal. In the other countries included in the survey, appointment of commissioners, decision-making or appeal procedures, and other institutional features imply at least some limitations to independence. For example, in Colombia, the President appoints the Superintendent who has full decision-making authority and appoints (or dismisses) the head of the

\footnotetext{
74 At least none have been publicly disclosed as of 2020.

${ }^{75}$ For example, in the last few years, the Peruvian competition authority has detected cartels affecting vulnerable consumers in, among others, pharmaceuticals, paper products, passenger transport, and vehicular natural gas, some of them using the leniency framework.

76 A comprehensive assessment of institutional independence is beyond the scope of this report.
}

prosecutorial unit within the superintendence. In Peru, the prosecutorial unit has organizational overlaps with the adjudicating unit. More broadly, the Peruvian competition authority does not enjoy the same level of independence as other sector regulators. And yet, both Colombia and Peru have imposed sanctions in high-profile cartel cases over the recent years. This alludes to their growing de facto technical independence. In Argentina, the 2018 reform that sets out a transition toward an independent authority is yet to be implemented. In general, strengthening institutional independence remains an important objective in the region. At the same time, the strong enforcement record in many economic sectors in Latin America suggests that limited independence does not seem to be the only binding constraint to effective antitrust enforcement in the banking sector.

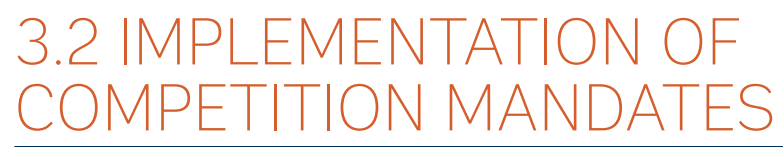

Competition authorities around the world actively deploy their mandate to address competition concerns in the financial services sector, but Latin American authorities still lag behind. A review of the recent merger and cartel cases of eight mature competition agencies in developing and advanced economies points to the relevance of antitrust enforcement in this sector. Between 2013 and 2017, 9 out of 32 cartel cases involved 
anticompetitive conduct in the financial services sector. ${ }^{77}$ None of these relate to Mexico or Brazil, suggesting that even among mature agencies, the financial services sector has not been under the same level of scrutiny in Latin America.

\section{The EU has recently tackled numerous large-scale anticompetitive practices in the financial services sector. EU competition enforcement during the GFC focused}

\footnotetext{
7 This analysis was conducted based on the Global Competition Review's 'Enforcer Tracker' feature that covers the following authorities: the DOJ and Federal Trade Commission, the EU's DG Comp, Germany's Federal Cartel Office, Brazil's CADE, Spain's Comisión Nacional de los Mercados y la Competencia, France's Competition Authority, and Mexico's COFECE.
}

mainly on merger review and state aid. However, over the last 10 years, the European banking and financial services sector has been subject to heightened antitrust scrutiny ${ }^{78}$ with fines amounting to over EUR 3 billion ${ }^{79}$ (see Box 9). Notable cases were initiated against price-fixing agreements related to financial benchmarks and instruments and abuse of dominance practices in payment systems. Since 2011, the European Commission (EC) has investigated cartels in credit default swaps, interest rate derivatives, foreign exchange, precious metals, and bonds. ${ }^{80}$

\footnotetext{
78 European Commission 2017.

${ }^{79}$ Global Competition Review 2019b.

${ }^{80}$ Global Competition Review 2019b.
}

\section{BOX 9: RELEVANT CASES IN ANTITRUST ENFORCEMENT, MERGER REVIEW, AND}

ADVOCACY INITIATIVES IN THE EU

\section{Anticompetitive agreements:}

- Price fixing by companies active in financial derivative products linked to the Euro Interbank Offered Rate (EURIBOR) The EC reached a settlement with Barclays, Deutsche Bank, RBS, and Société Générale in December 2013, with fines imposed totaling almost EUR 1.5 billion (2011).

- Price fixing by UBS, RBS, Deutsche Bank, JP Morgan, Citibank, and broker RP Martin-for discussions between traders at those banks about their Japanese yen LIBOR with fines amounting to EUR 670 million (2013).

- Price fixing by RBS, JP Morgan, Crédit Suisse, and UBS regarding Swiss Franc IRDs and exchanging information on trading positions and intended prices for future Swiss franc LIBOR submissions with fines amounting to EUR 94 million (2014).

\section{Abuse of dominance:}

- Anticompetitive practices in payment cards (Morgan Stanley/Visa, Cartes Bancaires, and Mastercard) and commitment decisions (2010 and 2014).

\section{Merger review:}

- Merger between Deutsche Börse and NYSE Euronext prohibited due to significant harm in the market for exchange-traded derivatives.
- Merger between Deutsche Börse and London Stock Exchange would have significantly reduced competition by creating a de facto monopoly in the market for clearing of fixed-income instruments.

- Merger between Banco Popular and Banco Santander, completed before formal merger clearance by the EG due to application of the failing firm theory.

\section{Advocacy initiatives:}

- Advocacy for overhaul of the securities and derivatives trading markets rulebook, to address lack of transparency in trading derivatives and financial instruments.

- Advocacy for the EU to enact new rules against market abuse in commodity and related derivative markets including governance, supervision, and prevention of manipulation of benchmarks such as LIBOR (2014).

- Advocacy on the payments sector, by promoting regulation to create an EU-wide level playing field, reduce fragmentation, and promote competition and innovation in payment systems.

- Advocacy on regulation of Credit Rating Agencies (the CRA Regulation), to stimulate competition in the industry.

- Mastercard and its licensees for agreeing to limit the possibility for merchants to benefit from better conditions offered by banks established elsewhere in the Single Market (2019). 
Competition authorities around the world have blocked banking mergers on the grounds of potential lessening of competition. In 2012, the German Competition Authority (Bundeskartellamt, BKA) blocked a local financial holding that owns a local savings bank from acquiring a minority share in another local savings bank. The BKA argued that the acquisition would have reinforced or at least established a dominant position by the acquiring party in the markets for private current accounts and for commercial loans to small- and medium-size companies in the district of the target party. ${ }^{81}$

However, in many merger cases, remedies were sufficient to address concerns for specific relevant markets and minimize risks of potential anticompetitive effects of the transaction. Mergers between banks typically imply changes in competitive dynamics in multiple relevant markets. For example, the Australia Competition and Consumer Commission (ACCG) in its assessment of the Westpac/Bank of Melbourne merger defined different geographic markets by product segment. It concluded that the relevant market for home loans was national, while the relevant market for small business banking was local. Concerns can therefore arise in a specific subset of the relevant markets affected by the merger. In a 2007 merger between an ABN AMRO and Fortis Bank NL, the EC identified competition concerns in the commercial customers segment but not in the retail banking segment. This allowed the authority to design specific remedies for each individual concern in the market. ${ }^{82}$

In the past, it has often been argued that specificities of local bank lending require particular attention to market concentration in this segment. The advantage of local banks in providing lines of credit to small- and medium-size businesses lies in their knowledge of local business conditions (OECD 2000). For example, the BKA argued that "private customers are reluctant to dispense with their local banks" and that "loans to smaller businesses require local presence of a bank." ${ }^{\prime 3}$

\footnotetext{
81 Global Competition Review 2012; Monopolkommission 2012.

${ }^{82}$ Note, however, that in hindsight, there seems to have been effects in the retail segment as well.

83 Bundeskartellamt 2012.
}

Accordingly, remedies are often designed to address concerns in local markets. A common remedy for a merger in retail or commercial banking is branch divestment in specific locations. For example, in 2016, a merger between Huntington Bancshares Incorporated's Acquisition and FirstMerit Corporation would turn the resulting party into the bank with the largest volume of deposits in Ohio. ${ }^{84}$ The DOJ entered into an agreement with the parties whereby they would divest 13 branches and associated deposits, loans, and customer relationships in specific counties.

In addition to structural remedies, such as divestment of branches, authorities have also seen the need for behavioral remedies. In the Ohio bank merger case referenced earlier, noncompete agreements were suspended for 180 days in those counties where branches had to be divested.$^{85}$ In Denmark, the competition authority conditioned a 2003 merger between Nykredit and Totalkredit to a cap for mortgage fees of 0.5 percent. $^{86}$

In LA-7, no mergers in the retail banking sector have been blocked in the last five years. While at least 17 mergers were reviewed by competition authorities, no mergers were outright blocked. The Central Bank of Uruguay considers that no mergers in the past five years have generated competition concerns. In fact, in 2015, it stated that the process of consolidation was conducive to competition. ${ }^{87}$ The only decision to block a merger in the financial sector was taken by Chile and it related specifically to payment systems (see Box 10).

However, competition authorities have imposed conditions on a series of mergers. For example, in 2016, Brazil's CADE cleared the acquisition of HSBC's Brazilian operations by Banco Bradesco subject to the imposition of remedies. It conditioned the deal to Banco Bradesco refraining from any further acquisitions in the financial sector until 2019. Banco Bradesco indicated that

\footnotetext{
84 DOJ 2016.

${ }^{85}$ DOJ 2016.

${ }^{86}$ Global Competition Review 2011.

${ }^{87}$ Teledoce 2015.
} 
BOX 10: MERGER PROHIBITION TO SAFEGUARD COMPETITION IN PAYMENT MARKETS IN CHILE

In 2018, the Chilean subsidiary of Santander sought to acquire stakes in the Society of Collection and Payment of Services (Servipag). Servipag offers services in digital payment and payment buttons, among others. Servipag is owned by two of Banco Santander's competitors, Banco de Chile and Banco de Crédito e Inversiones. Chile's

Sources: FNE 2018; Global Competition Review 2018a. competition authority, the National Economic Prosecutor, prohibited the deal as it would lessen competition substantially and result in the risk of coordinated effects. This was the second decision to block a merger in Chile's merger regime that came into force in June 2017. it would still proceed with any transactions that BCB considered to be of interest to the country's financial system. Other behavioral remedies imposed on this deal included Banco Bradesco encouraging HSBC customers in specific municipalities to transfer their loans to smaller financial institutions. ${ }^{88}$

\section{Some mergers with potential anticompetitive effects} in LA-7 may not have been subject to review. As of 2019, in Peru, ex ante merger review in the banking sector was carried out only by the banking regulator focusing on prudential concerns with a cross-sectoral merger review law to address competition concerns expected to enter into force in early 2021. Colombia's merger control system has limited applicability: 'conglomerate mergers' are not subject to ex ante merger review ${ }^{89}$ which applies only to mergers of parties in the same economic activity or within the same value chain (that is, horizontal and vertical mergers). ${ }^{90}$ In Colombia, this limitation may be critical as 3 of the 13 financial conglomerates represent around 52 percent of the assets administered by fiduciary societies (See Box 11). In

88 Global Competition Review 2016; Reuters 2016.

${ }^{89}$ Firms within a conglomerate offer several related products and services that are not necessarily competing nor are part of the same value chain. Conglomerate mergers may raise competition concerns due to multiple reasons. They may reduce potential competition from the acquired firm that could have otherwise contested the product market in question or at least constituted a potential market entrant. This has been the emphasis of the U.S. merger analysis. Mergers with conglomerate effects may also raise concerns due to non-coordinated effects. The EU has focused on the risk of conglomerates excluding competitors through tying, bundling, or leveraging of portfolio effects.

${ }^{90}$ Colombia's Financial Conglomerate Law (No. 1870 of 2017) does not include provisions related to competition effects.
Brazil, conglomerate mergers are subject to merger control if a party acquires 20 percent or more of the interest. ${ }^{91} \mathrm{In}$ Mexico, portfolio effects of conglomerate mergers have been considered in at least three merger review cases. ${ }^{92} \mathrm{In}$ Chile, the merger control guidelines specifically refer to the applicability to conglomerates. ${ }^{93}$ The recently updated merger control guidelines in Argentina also specify that conglomerate mergers may be subject to review. ${ }^{94}$

\section{Competition authorities can still address harmful conduct that arises from market consolidation.}

Even if a specific merger does not fall within the scope of ex ante control (due to the nature or size of the merger), authorities can be vigilant of anticompetitive practices by the merged entity, such as abuse of dominance. In Colombia, for example, the Superintendencia de Industria y Comercio (SIC) can open investigations into any company if there are reasonable indications of anticompetitive conduct, including such conduct that may become more likely after a conglomerate merger.

In LA-7, there have been very few antitrust investigations or advocacy initiatives in the banking sector. Among the authorities surveyed, only Mexico has

\footnotetext{
91 Resolution Cade No. 02, article 10.

92 OECD 2002.

93 Guía de Competencia, Fiscalía Nacional Económica, Chile (2017). https://www.fne.gob.cl/wp-content/uploads/2017/10/Guia-de-competencia.pdf

94 Lineamientos para el control de las concentraciones económicas (2018). https://www.argentina.gob.ar/sites/default/files/lineamientos_concentraciones_economicas_0.pdf
} 


\section{BOX 11: CONGLOMERATES IN THE COLOMBIAN FINANCIAL SECTOR}

The relative importance and cross-sectoral scope of conglomerates with their nucleus in the Colombian financial sector are considerable. In 2017, the Financial Supervisor (Superintendencia Financiera de Colombia, SFG) identified at least 13 economic groups that included at least two entities under the SFC's supervision. These 13 financial conglomerates amounted to 77 percent of the financial system's assets and 87 percent of gross domestic product (GDP), according to the SFC. Relevant Colombian cross-sectoral legislation excludes conglomerate mergers from mandatory review. Additionally, until recently, financial conglomerates were not fully under the SFG's supervision (for example, nonsupervised holding companies and their foreign subsidiaries).

In 2015 and 2016, the Organisation for Economic Co-operation and Development (OECD) had already noted that the Colombian banking sector was dominated by a few large conglomerates whose formation had been encouraged for many years. This trend increased concentration and decreased contestability in the Colombian banking system. In fact, according to SFC information, conglomerates went from assets equivalent to US\$3,861 million and 29 subsidiaries in 2006 to assets equivalent to US\$91,222 million and 220 subsidiaries in 2018. Since conglomerate mergers are shielded from review, the

Sources: La República 2019; OECD 2015, 2016b; SFC 2018, 2019a, $2019 b$.
OECD recommended an amendment to the merger law to bring conglomerate transactions within its scope.

In 2019, Law 1870 entered into force and, for the first time, enabled the SFC to, among others, (a) fully supervise financial conglomerates applying prudential standards, (b) review and authorize any investment directly or indirectly made by the conglomerate's holding company, and (c) order divestitures or other changes to the conglomerate's structure when necessary to enable or facilitate proper supervision. However, these tools are geared to avoid strategic, concentration, and contagion risks and address other prudential concerns and no specific reference is made to preventing anticompetitive effects of concentrations or of other conducts involving conglomerates.

According to the SFC's information, financial conglomerates in Colombia include Sura冈Bancolombia, Aval, Bolívar S.A., BBVA Colombia, Fundación Social, Coomeva, Scotiabank Colombia, Itaú Colombia, BNP Paribas Colombia, BTG Pactual Colombia, GNB Sudameris Colombia, Credicorp Capital Colombia, and Skandia Colombia. The group includes four 'systemic banks' (Banco de Bogotá from Aval, Bancolombia from Sura-Bancolombia, BBVA from BBVA Colombia, and Davivienda from Bolívar S.A.). led an investigation against financial services companies. This investigation did not target the retail banking services but rather the manipulation of sovereign bond prices (see Box 12). In some cases, across Latin America, banks have been subject to investigation only due to their participation in the payment system market in its different segments (for example, as owner of payment infrastructure, switches, or acquirers).

\section{Antitrust enforcement and advocacy efforts have focused on payment systems and other fintech markets. There have been at least five investigations into card payment systems and three market studies in this sector over the last five years. Competition authorities in Argentina, Chile, Mexico, and Peru have been particularly active in enforcing competition in payment systems (see}

Box 13). For example, in April 2019, Brazil's competition authority (CADE) opened an investigation against Banco Bradesco. The bank had allegedly impeded its clients from connecting their checking accounts to a third-party application. ${ }^{95}$

\section{Some banking regulators have promoted competition through regulatory reform, mostly in the payment systems market. At least three central} banks in Latin America saw the need to promote competition in payment systems. Argentina lowered interchange fees and MDRs (see case study in Annex 2). Brazil mandated interoperability for payment systems and Chile introduced new regulation for the credit card market.

\footnotetext{
${ }^{95}$ Competition Policy International, 2019.
} 


\section{BOX 12: RECENT INVESTIGATION BY MEXICAN COMPETITION AUTHORITY INTO SOVEREIGN BOND MARKET}

In 2016, the Mexican competition authority (COFECE) initiated an investigation into agreements affecting the Mexican sovereign bond market between 2006 and 2016. Banks under investigation reportedly include BBVA, Santander, Citibanamex, JP Morgan, Bank of America, Barclays, and Deutsche Bank.

Investigations allegedly started based on a leniency application from one of the involved banks. In October 2019,

Sources: COFECE 2019; Vanguardia 2019.
COFECE issued a preliminary liability opinion ('Dictamen de probable responsabilidad') which officially initiates prosecution of the alleged anticompetitive practices of price manipulation through limitations to sales and acquisitions of bonds. The investigation is the largest ever initiated into the banking sector by the competition authority and COFECE has been the target of backlash from the financial regulator.

\section{BOX 13: PERU: MARKET STUDY IN PAYMENT SYSTEMS AS REGULATORY THREAT}

In November 2018, INDECOPI, the Peruvian Competition Authority, initiated a market study regarding competition conditions in the Peruvian payment systems market. The study covers credit and debit card payment systems as well as fintech operators such as aggregators or payment gateways. These market players are regulated and/or supervised by the Instituto Nacional de Defensa de la Competencia y de la Protección de la Propiedad Intelectual (INDECOPI), Superintendencia Nacional de Banca, Seguros y AFP (SBS), and Banco Central de Reserva del Peru (BCRP). The study is a joint initiative between INDECOPI and BCRP, the latter as the payment systems regulator.

According to the opening report, INDECOPI will evaluate the hypothesis that reduced possession and use

Sources: INDECOPI 2018; OECD 2019a.

In other retail banking markets, however, the number of regulatory initiatives to encourage entry and promote customer mobility or others to address barriers to entry has been very limited.

Based on the information available, only Mexico has initiated a systematic effort to promote pro-competitive regulatory reform. In 2014, as a result of the Mexican competition authority's investigation into competition conditions in the financial sector, 36 recommendations were made regarding policy and regulatory reform. Some of payment cards by consumers can be explained by the structure of the market (vertical integration) and exclusivity agreements. Only 9 percent of the population in Peru uses a credit or debit card. There are only four acquiring companies under the Brand Aligned Acquiring Consolidation model (that is, each acquiring entity works with only one card network): (a) VisaNet with Visa brand, (b) Procesos Medios de Pago S.A. with Mastercard, (c) Expressnet with American Express-Amex, and (d) Banco Financiero with Diners. The market has only two payment processors: VisaNet for Visa and Procesos Medios de Pago for Mastercard, Amex, and Diners. The study will analyze acquiring companies, issuing banks, merchants, and cardholders. of the recommendations adopted included creation of electronic files for depositors, and introduction of mobile payments regulations, among others. Most recently, the competition authority has provided recommendations with respect to obligations for banks under the fintech legal framework (see Box 14).

Table 6 summarizes the advocacy and enforcement activities by LA-7 authorities over the past five years according to the information reported in the survey. 


\section{BOX 14: COMPETITION CONSIDERATIONS FOR MEXICAN FINTECH BILL}

In October 2017, the Mexican competition authority, COFECE, provided procompetitive recommendations to the proposed Fintech law. This law would regulate collective financing and electronic payment institutions and transactions with virtual assets. These recommendations were focused on including regulations to ensure that fintechs were able to compete with traditional finance institutions through access to information and financial services, which COFECE defined as essential assets.

COFECE recommended to

- Explicitly establish that users of financial services are the owners of their information and regulate the considerations for the transfer of data;

- Regulate terms/conditions and fees that banks may charge fintech companies for sharing transaction data of individual customers. Fintech's access to users' information under control of traditional financial entities should be facilitated through nondiscriminatory fees and conditions established by financial authorities;

- Mandate that traditional finance institutions grant nondiscriminatory access to their banking services to fintechs; and

- Establish neutrality, meaning that fintechs are free to adopt any infrastructure/technology to provide their services. Regulation should not constitute a barrier for fintechs to decide how to offer their services, and it should not be stricter than that applicable to the rest of the financial sector.

The Fintech Law was published in March 2018. The law, which takes full effect in 2020, adopted the abovementioned recommendations submitted by COFECE.

Sources: COFECE. OPN-007-2017, https://www.cofece.mx/cfcresoluciones/docs/Opiniones/V20/6/3953499.pdf; Article 56, 73, 76, and 103 of the Mexican Law to Regulate Institutions of Financial Technology, http://www.dof.gob.mx/nota_detalle.php?codigo=5515623\&fecha=09/03/2018

TABLE 6: ADVOCACY AND ENFORCEMENT ACTIVITIES

\begin{tabular}{|c|c|c|c|c|}
\hline & Practices & Mergers & Advocacy initiatives & $\begin{array}{l}\text { Pro-competition } \\
\text { regulation }\end{array}$ \\
\hline Argentina & $\begin{array}{l}\text { - Six investigations, no } \\
\text { sanctions } \\
\text { - One of the investigations } \\
\text { concluded in the } \\
\text { imposition of remedies } \\
\text { (payment systems) }\end{array}$ & & & \\
\hline Brazil & $\begin{array}{l}\text { Investigation into foreign } \\
\text { exchange market for } \\
\text { collusive practices }\end{array}$ & $\begin{array}{l}\text { - Remedies were imposed } \\
\text { in mergers in the payment } \\
\text { systems market. } \\
\text { - At least four mergers have } \\
\text { been reviewed. }\end{array}$ & & $\begin{array}{l}\text { - Introduction of } \\
\text { interoperability for } \\
\text { payment systems }\end{array}$ \\
\hline Chile & $\begin{array}{l}\text { - } 15 \text { investigations, no } \\
\text { sanctions } \\
\text { - Currently investigating } \\
\text { credit card market and } \\
\text { interbank rates }\end{array}$ & $\begin{array}{l}10 \text { reviews in banking } \\
\text { sector, all approved } \\
\text { without conditions } \\
\text { - Three mergers reviewed } \\
\text { in related markets, only } \\
\text { one blocked (payment } \\
\text { systems) }\end{array}$ & $\begin{array}{l}\text { - Market study on } \\
\text { the promotion of } \\
\text { competition in payment } \\
\text { systems } \\
\text { - Competition in retail } \\
\text { banking (2010) }\end{array}$ & $\begin{array}{l}\text { New regulation of } \\
\text { credit card systems }\end{array}$ \\
\hline
\end{tabular}




\begin{tabular}{|c|c|c|c|c|}
\hline & Practices & Mergers & Advocacy initiatives & $\begin{array}{l}\text { Pro-competition } \\
\text { regulation }\end{array}$ \\
\hline Colombia & - One investigation & & & \\
\hline Mexico & $\begin{array}{l}\text { Investigation related } \\
\text { to collusive practices } \\
\text { by seven banks for } \\
\text { manipulating Mexican } \\
\text { sovereign bonds prices } \\
(2019)\end{array}$ & & $\begin{array}{l}\text { - Competition in credit } \\
\text { card systems (2008) } \\
\text { - Financing for micro and } \\
\text { small businesses (2008) } \\
\text { - Competition conditions } \\
\text { in financial sector } \\
\text { markets (2014) } \\
\text { Opinion on new fintech } \\
\text { regulations (2017) }\end{array}$ & \\
\hline Peru & None & $\begin{array}{l}\text { No mergers have been } \\
\text { blocked }\end{array}$ & $\begin{array}{l}\text { - Market study of } \\
\text { competition in payment } \\
\text { systems }\end{array}$ & \\
\hline Uruguay & $\begin{array}{l}\text { Two investigations } \\
\text { regarding collusive } \\
\text { practices in the credit } \\
\text { card market. No sanction }\end{array}$ & & & \\
\hline
\end{tabular}

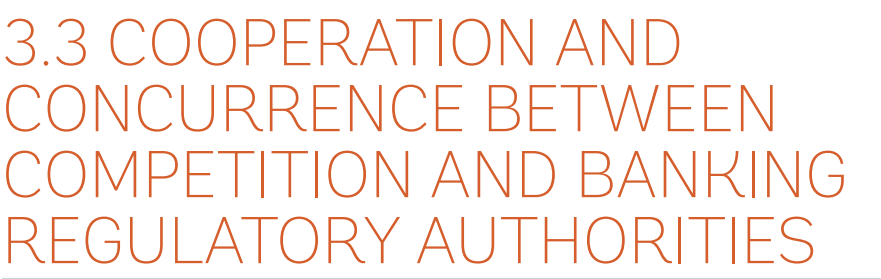

As of 2019, competition policy was seldom an explicit part of the mandates of banking regulators around the world. Nevertheless, competition contributes to achieving other objectives in those mandates. As the 2019 World Bank's BRSS ${ }^{96}$ shows, only 9 percent and 22 percent of banking regulators in high-income and developing economies, respectively, have an explicit mandate on competition or antitrust policy (Figure 18). ${ }^{97}$ However, most regulators have mandates on areas that are related to or depend on healthy competition, such as promotion of financial inclusion and economic development, and market conduct. In this sense, competition policy is directly

\footnotetext{
96 https://datacatalog.worldbank.org/dataset/bank-regulation-and-supervision-survey\#tab2

97 For a banking regulator to have a mandate on competition does not remain without controversy. For example, in 2016, the Dutch Finance Minister openly opposed the inclusion of a competition objective in the banking regulators' mandate, as it could detract from prudential supervision and consumer protection. This happened in the context of an initiative to promote entry of innovators in the banking sector (ACM 2017).
}

or indirectly an integral part of the mandate of banking regulators. This can foster a complementary vision of stability regulation and competition policy.

\section{In Latin America, the legal framework of banking regulators and/or central banks often includes competition as a regulatory principle. In Latin} America, Bolivia, Colombia, Costa Rica, Nicaragua, and Uruguay reported having banking regulators with a competition or antitrust policy mandate. Argentina, Brazil, Colombia, Ecuador, El Salvador, Honduras, Mexico, Nicaragua, Paraguay, Peru, and Uruguay reported having a banking regulator with a market conduct mandate. Finally, Argentina, Bolivia, Brazil, Chile, Colombia, Costa Rica, El Salvador, Mexico, Paraguay, Peru, and Uruguay reported having a banking regulator with a financial market access and development mandate. Even if sector regulators do not enforce competition law, their own statutory powers include the promotion of competition in their sectors to various degrees. As a result, authority in the field of competition policy in banking services in Latin America is usually allocated under a shared jurisdiction model. Multiple agencies are in charge of either safeguarding or promoting competition. These include a cross-sectoral competition authority, a specialized banking sector regulator, and a central bank. 
FIGURE 18: SCOPE OF MANDATE OF BANKING REGULATORS

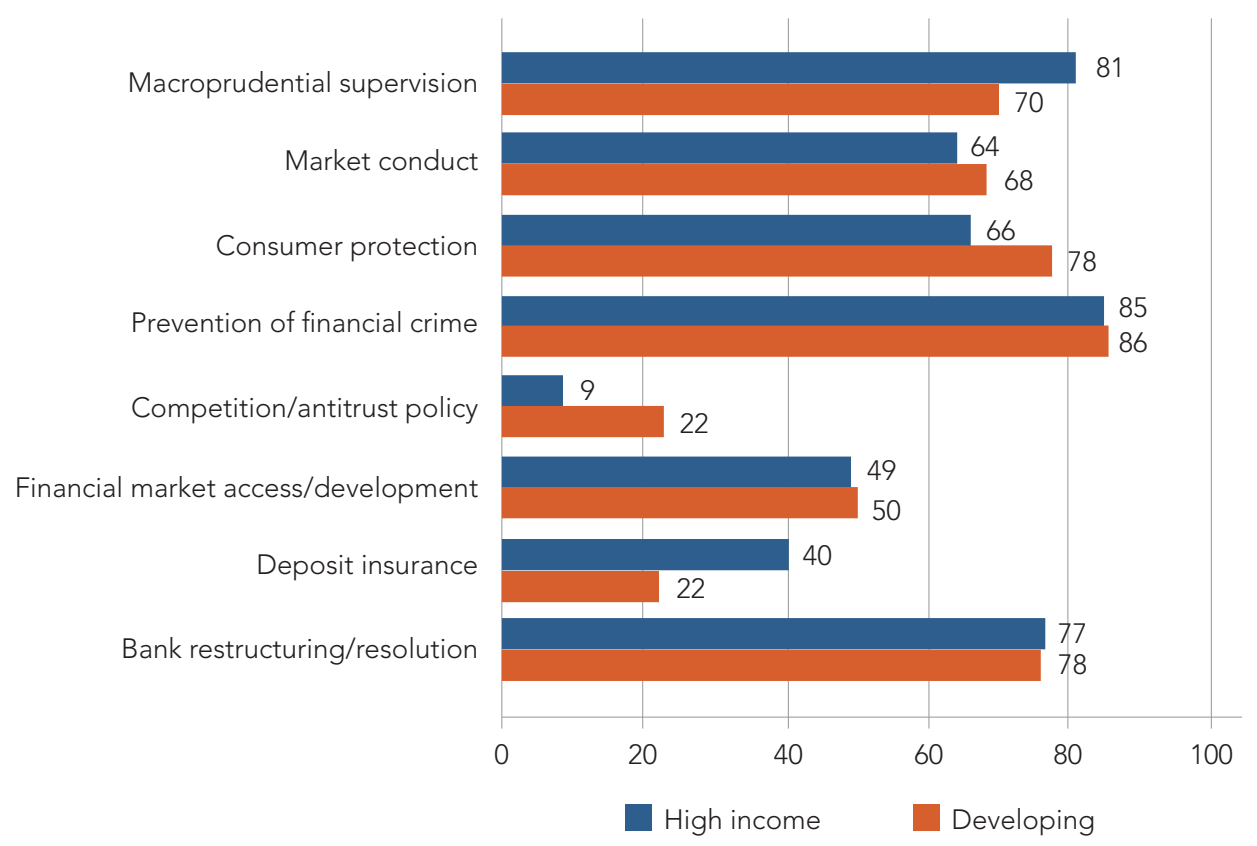

Source: World Bank Group BRSS 2019.

Powers to intervene in the sector differ between actions that shape market structure and incentives for firms (ex ante) and those that correct firm behavior (ex post). Generally, only competition authorities can investigate and sanction anticompetitive practices by financial services firms. However, powers to review mergers in the sector are an ex ante intervention that is typically shared among competition authorities and banking regulators to address both competition and stability concerns. In most of the LA-7 economies included in our survey, competition authorities and banking regulators must both clear a proposed transaction with each institution focusing on their key policy objective (that is, competition and financial stability). Finally, both competition authority and regulator typically have powers to promote pro-competition regulation. While sector regulators have rule-making powers and must, in principle, adhere to pro-competition standards, competition authorities can advocate for pro-competition regulatory reform.

In sum, most competition policy regimes in the banking sector in LA-7 can be qualified as nonexclusive. The most common area of jurisdictional and policy tool overlap is merger review. This is not unusual for a regulated sector. However, in addition, at least some portion of the mandate to promote competition is shared by more than one agency. Table 7 summarizes regulatory jurisdiction in the banking sector for the Latin American countries included in the survey.

Overlap in competition law enforcement in the banking sector requires effective coordination between competition authorities and banking regulators. For example, for merger review in the banking sector, financial stability considerations put forward by the banking regulator may override competition concerns and be reason enough to clear a merger. Ideally, the institutional setup should include a mechanism to assess both competition and stability concerns. When enforcement of merger review has not outright been carved out of the competition authority's mandate and given to the banking regulator, nonbinding opinions are a typical mechanism for coordination. For example, the banking regulator may raise financial stability or other public interest considerations in the context of merger review by a competition authority. 


\begin{tabular}{|c|c|c|c|}
\hline & Competition authority & Regulatory/supervisory agency & Gentral bank \\
\hline Anticompetitive practices & $\begin{array}{l}\text { Argentina } \\
\text { Brazil } \\
\text { - Chile } \\
\text { - Colombia } \\
\text { - Mexico } \\
\text { Peru }\end{array}$ & & - Uruguay \\
\hline Merger review & $\begin{array}{ll}\text { - } & \text { Argentina } \\
\text { - } & \text { Brazil } \\
\text { - } & \text { Chile } \\
\text { - } & \text { Colombia } \\
\text { - } & \text { Mexico } \\
\text { - } & \text { Peru }\end{array}$ & $\begin{array}{l}\cdot \text { Chile } \\
\text { - Colombia } \\
\text { • Mexico } \\
\text { - Peru } \\
\text { - Uruguay }\end{array}$ & - Brazil \\
\hline Competition advocacy & $\begin{array}{l}\text { Argentina } \\
\text { Brazil } \\
\text { - Chile } \\
\text { Colombia } \\
\text { - Mexico } \\
\text { Peru }\end{array}$ & & \\
\hline $\begin{array}{l}\text { Regulatory principle of } \\
\text { 'competition promotion' }\end{array}$ & & • Peru & $\begin{array}{l}\text { - Argentina } \\
\text { - Brazil } \\
\text { - Peru }\end{array}$ \\
\hline
\end{tabular}

Jurisdiction allocation between competition authorities and banking regulators varies considerably among countries. Competition policy enforcement in the banking sector may follow different models: it may be assigned to the sector-specific regulator (usually as a secondary objective of its mandate), kept in the competition authority, given to both agencies in a parallel and connected procedure (shared powers), or given to both agencies in a parallel but independent procedure (concurrent powers). After the GFC, the trend seems to be to include competition policy objectives in the mandate of banking regulators and to make explicit any derogation of competition law. The legal framework could explicitly or implicitly (lex specialis principle) establish the general preemption of competition law by sector-specific regulation. Competition law could hence be overridden in favor of prudential concerns in certain circumstances. The legal framework could also limit the preemption to a specific tool, like merger review. Whether in joint or parallel procedures, the final say must be assigned to either entity or to a third party (for example, Finance or Economy
Ministry), or concurrent approvals required (for example, double greenlight), and circumstances where prudential concerns could override competition concerns should be defined..$^{98}$

Even among OECD countries, the scope and modalities of interaction and coordination differ significantly and seek to ensure balance between different policy objectives. Collaborative activities include consent before licensing; comments, consultations, or opinion giving on regulations, guidelines, or case outcomes; sharing of information or cases; or discussions regarding remedies. The execution of Memoranda of Understanding (MoUs) is commonly used as a way for agencies to define the details of required procedures. Informal and ad hoc techniques are employed for specific issues (for example, task force for a particular investigation or case) or ongoing coordination platforms could be put into place (for example, working groups). ${ }^{99}$

\footnotetext{
98 OECD 2016a.

${ }_{99}$ Carletti and Smolenska 2017.
} 


\section{BOX 15: COORDINATION OF POLICY IMPLEMENTATION TOOLS: U.K. CONCURRENCY FRAMEWORK AND MERGER REVIEW MODEL}

The United Kingdom's Financial Conduct Authority (FCA) has a mandate that includes as primary objectives consumer protection, integrity, and promotion of effective competition. Thus, since 2015, the Competition and Markets Authority (CMA) and the FCA have concurrent powers to enforce competition law (except merger review) and carry out market studies in the banking sector. The Payment Systems Regulator (PSR) is a subsidiary of the FCA and has concurrent competition law powers. Finally, the Prudential Regulation Authority (PRA), responsible for prudential regulation and supervision, has a secondary objective to facilitate effective competition but has no formal concurrent competition powers.

The CMA and FCA entered into an MoU on June 12, 2014, that set out a framework for cooperation in relation to competition issues, with its most recent revision in July 2019. The key features include the following:

- The parties declare that they will use their powers to achieve more competitive outcomes in the financial services industry.

- The parties will always consult each other before the initial exercise of concurrent competition law powers in suspected infringement to competition prohibitions and before launching a market study.

- Parties will engage in open dialogue and share relevant information on cases and consult each other in issues that might have significant implications for the other.

- Regarding case allocation, the parties will endeavor to reach an agreement on which agency will exercise concurrent competition powers. The CMA has the final decision.
Under this framework, according to a CMA self-assessment, the FCA and CMA work closely in investigations, share key information, and comment on key documents. Additionally, they have informal discussions and share know-how and relevant expertise (policy or practical experience).

Merger review is performed primarily by the CMA across all industries. The CMA has informal arrangements to seek input from sectoral regulators or through a formal consultation process. The Enterprise Act allows for intervention in mergers by the Secretary of State (SoS) on specific public interest grounds, which expressly includes the stability of the U.K. financial system. The CMA must inform the SoS of a merger investigation. Then, the SoS may issue an intervention notice and the CMA must report if the merger reduces competition. The SoS makes the final decision on the merger. As of 2017, the SoS had issued only one intervention in the interest of maintaining the stability of U.K. financial system. In the Lloyds/HBOs merger (2008), the SoS decided that stability concerns overrode competition concerns identified by the then Office of Fair Trading and decided that the merger would not be referred for further investigation.

In the last 10 years, banking regulators have provided input in several merger review cases. For example, the Mastercard/Vocalink payment systems merger involved the PSR in the evaluation of the conditions proposed by the parties. The PSR also ended up proposing its own requirements to clear the merger that were included by the CMA in its final decision.
In practice, the merit of competition considerations and financial stability concerns have to be balanced in each specific government intervention in the market, such as regulatory design and merger review. The most common incidences when authorities must evaluate the possibility to align both policy objectives (stability and competition) are in the design of regulations and the review of mergers and acquisitions. The review of mergers under stability and competition considerations may result in conflicting recommendations. Prudential control of mergers aims to corroborate integrity and stability as well as to verify that the merged entity meets the requirements for authorization (capitalization, asset quality, performance, and proper shareholders, among others) ${ }^{100}$ In competition policy, the most important objective is to prevent the substantial lessening of competition that is not justified by efficiency gains.

\footnotetext{
${ }^{100}$ Carletti and Smolenska 2017.
} 
BOX 16: OTHER EXAMPLES OF COORDINATION MECHANISM BETWEEN COMPETITION AUTHORITIES AND BANKING REGULATORS

The Netherlands. The Minister of Finance has final decision-making authority to overturn a decision by the competition authority. A protocol exists between the competition authority and the banking regulator that defines cooperation in mergers involving the banking sector in which there is extreme urgency (for example, insolvency) which enables parties to bypass the normal notification process.

The United States of America. Mergers are notified to both the Federal Reserve (Fed) and the Antitrust Division of the DOJ. Both reviews run in parallel and take different approaches, but the Fed has an obligation to prevent anticompetitive mergers except when superseded by public interest reasons. If the merger is objected by the DOJ, the approval of the transaction granted by the Fed is suspended.
Singapore. The competition authority has an obligation to advice other government agencies in competition policy. Engagements with the banking regulators increased from 1 in 2009 to 17 in 2017. The advice relates to advocacy and rule-making initiatives by the banking regulator. Cooperation is organized under the Community of Practice for Competition and Economic Regulations, an interagency platform to share practices and experience on competition and regulatory matters. Finally, a representative of the banking regulator is a member of the board of the competition authority.

Finland. The competition authority has exclusive enforcement of competition policy, including mergers in the banking sector for which it consults with the banking regulator. Before the competition authority takes any enforcement action or initiatives in the banking sector, it consults with the regulator.
The international experience varies in how institutions have used their formal and informal powers to intervene in merger cases. Japan's competition authority requires consent from the banking regulator before clearing a merger. A recent merger case with effects on retail banking in a specific geographic area involved careful design of remedial conditions before approving the merger (see Box 17). Australia's approvals of mergers in the context of the GFC considered evidence and material provided by the banking regulators (see Box 18). In Israel, the competition authority was able to block a recent merger proposal despite the favorable opinion by the central bank. It was overruled by the competition tribunal for considerations unrelated to the central bank's opinion (see Box 19). In the United Kingdom, there is at least one precedent of the competition authority being overruled (see Box 15).

\section{In LA-7, the implementation of coordination mechanisms between the mandates of different authorities is usually not established by applicable}

law. For example, Argentina's Central Bank has an explicit mandate to coordinate the defense of competition with the competition authority. ${ }^{101}$ However, the collaboration mechanisms and respective boundaries of their mandates are not developed in the law. As an exception, Peru has a framework that guides overlaps between sectoral regulation and antitrust enforcement. Under Peru's principle of 'supletoriedad', sectorial regulation imposed with the purpose of promoting or protecting competition trumps antitrust rules, meaning that the breaching of these regulations has to be sanctioned under sectorial rules and not using antitrust provisions. This is applied to the financial sector too (see Box 20).

${ }^{101}$ See Art. $4(\mathrm{~h})$ and 14(t) of Law 24.144 


\section{BOX 17: CASE STUDY: MERGER REVIEW OF FUKUOKA FINANCIAL GROUP INC. AND THE EIGHTEEN BANK LTD.}

In Japan, when reviewing share acquisitions in the banking sector, the competition authority, the Japan FairTrade Commission (JFTC), must consult with the banking regulatory agency, the Financial Services Agency (FSA).

In 2016, the JFTC opposed the merger between Fukuoka Financial Group Inc. and the Eighteen Bank Ltd. The merged parties would hold a market share of 70 percent in the lending market of the southern prefecture of Nagasaki with limited competitive pressure. The merger was meant to help the parties deal with the difficult situation of many of Japan's regional banks: ageing population had caused few lending opportunities and excess deposits.

The FSA had been promoting the consolidation of regional banks to raise profitability. It opposed the decision and even pushed for an exemption from antitrust law to help smaller banks survive declining regional population and economies, as well as deteriorating earnings due to low interest rates. The FSA has also raised concerns regarding regional banks' skills to manage the risks associated with handling complex portfolios of foreign securities.

After a full 'Phase II review' and an exceptionally long review period, the JFTC approved the transaction in
August 2018. The JFTC accepted the remedies proposed by the parties to ensure that competition would not be restrained:

- Assign approximately $¥ 100$ billion worth of account receivables of commercial loans to competitors before the acquisition.

- Establish a monitoring mechanism to control lending rates.

- Submit periodic reports to the JFTC and adhere to the other remedies.

After the approval, the banks stated that the merger would allow them to achieve economies of scale and keep their network on the many islands of Nagasaki.

This decision is the first ever merger approved between two dominant regional banks by the JFTC and is considered to be a precedent for the widespread regional bank consolidations that the FSA is promoting. The FSA is still making the case for a special treatment of mergers involving regional banks.

\section{BOX 18: CASE STUDY: MERGER REVIEW IN AUSTRALIA DURING THE GLOBAL FINANCIAL CRISIS}

In Australia, mergers require approval from the Treasurer. While the ACCC had cleared the Westpac acquisition of St. George's Bank shortly before the breakout of the 2008 GFC, the Treasurer imposed conditions for its approval in October 2008. These conditions included maintaining branches, retaining retail banking brands, and removing ATM fees for transactions between the two merging parties' networks.

In a review in December 2008, the ACGC cleared Commonwealth Bank of Australia's acquisition of BankWest.
The ACCG referred to 'global financial conditions' that would risk BankWest no longer being able to exert the same competitive pressure. At the time, its parent company in the United Kingdom was facing significant funding difficulties. Hence, the lowering of competition pressure would be similar if the merger proceeded or not. In the process, the ACCC consulted with the Reserve Bank of Australia (RBA) and Australia's Prudential Regulation Authority (APRA), both of which provided evidence for this assessment. 


\section{BOX 19: CASE STUDY: COMPETITION AUTHORITY'S DECISION POWER OVER BANKING MERGERS IN ISRAEL}

In 2017, the third-largest bank in Israel, Mizrahi Tefahot, announced its intention to acquire its competitor Union Bank (known as Bank Igud), the country's sixth-largest bank. Israel's Central Bank viewed this merger favorably. It argued that it would allow Mizrahi to compete more effectively with the two top banks. Ministers of Economy and Finance spoke out against the merger. In May 2018, the Israel Competition Authority (ICA) decided to block the deal. Among others, it referred to Union Bank's successful and unique competitive strategy in attracting customers.

In November 2019, the Jerusalem Competition Tribunal overruled the ICA and approved the merger. However, the ruling did recognize potential damage to competition in the credit market for the diamond business. Union Bank reportedly finances 25 percent of Israel's diamond industry. The court ordered the ICA to review if this concern could be addressed with remedies.

\section{BOX 20: JURISDICTIONAL DELINEATION IN PERUVIAN COMPETITION POLICY IN THE BANKING SECTOR}

The Peruvian competition law (Supreme Decree 0302019-PCM) grants the competition agency (INDECOPI) the authority to investigate and sanction anticompetitive practices in the banking sector. However, the law (article 3) does not apply to conduct that is the result of sectoral regulation. Such regulation is enacted and enforced by specialized regulatory agencies like the financial regulator, SBS, and the central bank, BCRP.

Banking Law (Law 26702) ensures a market-based regulatory design. It provides that fees and interests are set freely (article 9) and includes an obligation by SBS to promote private savings (that is, protect depositors through prudential regulation) under free competition (article 130 and 131). Implementing regulations (SBS Resolution 3912-2018) empower SBS's regulatory unit to propose mechanisms to prevent anticompetitive conduct in the market (article 25 (j)). Such mechanisms are supervised by SBS's Market Conduct Unit.
BCRP enacts regulations for operations among banks and is the main regulator of payment systems (Decree Law 26123). According to the legal framework (Law 29440), BCRP must ensure that payment systems operate under competitive conditions (article 10 (a)). This allows BCRP to issue pro-competitive regulation.

Peru recently introduced a merger control, but the legal framework (Urgency Decree 013-2019) is not yet in effect. This law gives INDECOPI authority to review mergers in any and creates no exception for the financial sector. It foresees that SBS must issue a nonbinding opinion regarding the concentration level and any effects on the affected market(s). Additionally, the merger must also be cleared by SBS under a prudential and systemic stability standard (Art. 12, Law 26702). The merger control law foresees a single decision-making authority for special circumstances: If there are imminent and relevant risks to the stability of the system, only SBS authorization is needed (article 16.3).
Where mandates of antitrust authorities and banking regulators overlap, the law generally does not foresee a mechanism to accommodate conflicting policy objectives. For example, in a merger review process, where there is overlapping jurisdiction, in most cases the law does not provide for a single decision authority but requires clearance from both the competition authority and the sector regulator (double greenlight). 
Only in Brazil, Peru, and Colombia can the banking regulator/supervisor unilaterally approve a merger even if the antitrust authority has raised competition concerns. In Brazil, the central bank and the competition authority both have mandates to review a merger. ${ }^{102}$ However, the decision by the central bank on whether financial stability is a concern can override the decision of the competition authority on whether the merger creates concerns for competition. In Peru, the new merger control law has adopted a similar model, where the banking regulator's decision will prevail if there are systemic risks (see Box 21). In Colombia, the banking supervisor can unilaterally clear a merger that exclusively involves parties under its supervision with an opinion from the competition authority regarding (a) the impact on competition of the merger and (b) any conditions for approval, if needed. ${ }^{103}$

${ }^{102}$ See General Competition Law (Law 12,529/11) and Banking Law (Law 4595/64).

${ }^{103}$ See Competition Law (Law 1340), as well as Law 155, and in particular Art. 28 of Law 1340.
Some authorities have developed formal collaboration protocols to address instances of jurisdictional overlap. For example, Brazil's competition authority and the central bank signed an $\mathrm{MoU}$ in 2018 on the merger review process. In August 2018, the competition authority (CADE) and the central bank approved the merger between Itaú Unibanco and XP Investimentos (see Box 21). In Peru and Colombia, the competition authority provides nonbinding opinions on merger cases to the regulatory authority which decides.

In practice, there seems to be no example of formal committees or interinstitutional bodies that review and jointly decide on the configuration and sanction of anticompetitive practices or the clearance of mergers. In all LA-7 countries surveyed, the decision is made either by two institutions separately or one institution with the inputs of another. However, there seems to be no instance in which institutions issue joint statements or decisions on a specific case.

\section{BOX 21: COOPERATION THROUGH AN MOU BETWEEN CADE AND BCB-ITAÚ/XP MERGER}

In February 2018, CADE and BCB signed an MoU to coordinate the assessment of anticompetitive practices and mergers involving companies in the financial sector and to agree on actions to promote competition. The $\mathrm{MoU}$ contains provisions regarding exchange of information and facilitation of consistency of assessment such as issuing guidelines and training programs. Most importantly, the agreement provides that mergers in the financial sector will be cleared jointly by CADE and BCB (double greenlight). However, if the merger could affect the stability of the financial system (systemic risk), then it will be cleared exclusively by BCB. In such a scenario, BCB will inform CADE of the reasons for the systemic risk assessment. CADE would still issue a decision approving the merger with no conditions, taking BCB's decision as proving efficiency and economic development justifications for approval. The MoU also states that CADE will be Sources: CADE 2018; Mayer-Brown 2018; OECD 2019a. responsible for assessing anticompetitive conducts in the financial sector but will consult with BCB before issuing a final decision and imposing penalties.

The first merger reviewed in the financial sector after the MoU was the Itaú Unibanco (Brazil's largest bank) acquisition of a stake in XP Investimentos, a firm in the financial services market (Merger Review 08700.004431/2017-16). The merger was approved after cooperation between CADE and BCB, subject to several commitments: (a) stronger governance mechanisms to ensure independence of XP management to address concerns on the reduction of competitive pressure, (b) nondiscrimination commitments and bans on exclusivity clauses to mitigate risks of discrimination or market foreclosure, and (c) prohibition for XP to target Itaú customers to prevent reinforcing the bank's dominant position. 


\subsection{COMPETITION POLICY DURING CRISES}

During economic or financial crisis, prevention of systemic bank failures can take precedence over other policy objectives, but this should not preclude pro-competitive designs of support measures. A review ${ }^{104}$ of the EU response to the 2008 GFC showed that during crisis times, there is a deviation from the competition policy standard case scenario (stable market conditions), and priority is given to preventing systemic bank failures. Lower competitive pressures may increase margins at distressed banks, cushioning the negative effects of widespread market turmoil (Fiordelisi et al., 2015). In such circumstances, interventions are mainly centered around state aid with a lenient (although not absent) merger control framework. ${ }^{105}$ However, even during a crisis, government interventions need not only be shielded

\footnotetext{
${ }^{104}$ Hasan and Marinč 2013.

${ }^{105}$ Interventions mentioned in the review include central banks acting as last resort lenders, granting direct or indirect of state aid (for example, tax advantages), regulator led bank liquidations, purchase and assumption agreements, and nationalizations. Potential conflicts with competition policy include merger control (purchase agreements), creation of implicit government guarantees (nationalization), and subsidies (barriers to entry).
}

from particularly strong political pressure but should more generally be aimed at preserving a level playing field among market participants. For example, distortive state aid may prevent more efficient firms from prospering and enhance excessive risk taking. Safeguarding stability, even at the expense of short-term distortion of competition, is usually the main objective of government intervention during a crisis. Nevertheless, intervention should be designed in such a way that mid- to long-term competition in the sector is not permanently affected (for example, temporary and with clear phaseout conditions).

\section{In the international experience, decisions regarding state aid to safeguard stability are reviewed under} competition considerations. During periods of financial turbulence, governments may need to support banks, in particular distress to safeguard stability of the broader financial system. International experience shows that these interventions can still be designed in a way to avoid unnecessary harm to the competitive environment. State aid design can be reviewed with respect to potential anticompetitive effects. For example, aid to individual banks is more likely to raise competition concerns. Remedies and restrictions to beneficiaries can be put in place to prevent long-term harm to competition (see Box 22). In its 2008

BOX 22: CASE STUDY: COMPETITION CONSIDERATIONS IN EUROPEAN STATE AID DESIGN

In 2008, the EC decided to approve a number of support measures to the banking industry in the United Kingdom. The measures involved bank recapitalization scheme, a Wholesale Funding Guarantee Scheme, and short-term liquidity measures. The United Kingdom argued that the measures did not involve undue distortions of competition, because they were open to any bank with significant business in the United Kingdom (open and nondiscriminatory). The EC accepted the behavioral commitments to be sufficient to prevent recipients from engaging in aggressive commercial strategies or expansion of its activities that would distort competition.

At the same time, the state aid involves behavior remedies. For example, the United Kingdom required all beneficiary banks of the 2008 package to maintain, over three years, the availability and active marketing of competitively priced lending to homeowners and to small businesses, at a level at least equivalent to 2007. In addition, for the wholesale funding guarantee scheme, it imposed a limit to the growth rate of the activity of all participating banks.

State aid to specific firms may require more extensive remedies. For the bailout of the Royal Bank of Scotland in the aftermath of the financial crisis, the EU put in place several remedial conditions. It originally sought the divestiture of a specific division. This division did not turn out to be independently profitable. In 2017, the EG therefore created a fund to support competition in the SME banking industry.

Sources: NS Banking 2019. 
guidance on the rules of state aid for financial institutions in the $\mathrm{GFC},{ }^{106}$ the $\mathrm{EC}$ proposed that, given the inherent risks of negative effects on non-beneficiary banks, to avoid distortions of competition, granting of state aid (guarantees, recapitalizations, controlled winding-ups, or similar liquidity assistance) should include objective and nondiscriminatory eligibility criteria; enforceable behavioral constraints (for example, market share ceilings, balance sheet limitations, and restrictions on commercial conduct); guarantees limited to retail deposits or targeted to specific source of difficulties; amount, intensity, and duration limited to minimum necessary with review every six months; and, if the aid is aimed at an individual institution, a restructuring/liquidation plan detailing the resolution of the underlying problem is required to be reviewed in light of long-term viability, minimization of state aid and private participation on the costs of restructuring, and minimization of the distortion of competition and unjustified benefits.

\section{Exemptions or tolerance of otherwise anticom- petitive agreements in the banking sector has not been deemed necessary or justified until the recent crisis triggered by Covid-19. Arguments for the application of the so called 'crisis cartels' figure can be brought to the front in financial crisis situations. The EC defines 'crisis cartels' or 'industrial restructuring agreements' as agreements that restrict competition invoking overcapacity}

${ }^{106}$ EC 2008. problems or economic crisis in a given sector to find joint solutions to industry-wide problems (usually related to capacity reductions or price fixing). ${ }^{107}$ Internationally, most competition policy regimes do not have exemptions for crisis cartels. During the GFC and in its aftermath, the EC did not relax anti-cartel enforcement in the banking sector and, in fact, took a stance against crisis cartels. ${ }^{108}$ In the context of the economic crisis generated by the Covid-19 pandemic, some governments have issued exemptions for cooperation among competitors that are in the interest of the consumer, aimed at ensuring access to critical supplies or guarantee essential service provision. Such exemptions have included the banking sector (see Box 23).

\section{In crisis situations, competition authorities apply merger review laws flexibly and take into account systemic risks when necessary, but this should not be equivalent to a more lenient assessment.} Crises cause financial distress to numerous firms and a merger with a stronger competitor is a common solution. During the GFC, the EC acknowledged that competition authorities could apply merger rules flexibly to deal with rapidly evolving market conditions (common in banking crisis to prevent collapse). ${ }^{109}$ In particular, a 2009 OECD

\footnotetext{
${ }^{107}$ OECD 2011

${ }^{108}$ Kroes 2010.

${ }^{109}$ Kroes 2010.
}

\section{BOX 23: EXAMPLES OF EXEMPTIONS GRANTED FOR COORDINATION IN THE BANKING SECTOR TO ADDRESS THE COVID-19 CRISIS}

The Australian competition authority authorized banks and other lenders to (a) coordinate for the deferral of repayments of loans to small businesses in sectors impacted by the pandemic with less than US $\$ 3$ million in total debt owed to credit providers, (b) provide relief packages for individuals and businesses affected by the pandemic (payment deferrals) and provide access to counter services, and (c) coordinate input to issue loans to consumers and small businesses funded by the federal government. The authorization provides statutory protection from action under competition law.
The Icelandic competition authority granted an exemption from the ban on collusion to banks and pension funds for loan repayment deferral and other uniform measures subject to monitoring of the central bank and an ad hoc competition law expert.

South Africa enacted regulations to exempt certain agreements or practices between banks and payment systems operators from provisions of the competition law to enable joint debt relief and other measures during the crisis, excluding price fixing. Banks are required to keep written records of all agreements. 
study ${ }^{110}$ concluded that, in a crisis context, competition authorities would face an increasing number of mergers where the failing firm defense ${ }^{111}$ may be put forward as an argument for the approval of the transaction. However, in general, conditions required for accepting a failing firm defense are strict and the burden of proof imposed on the parties is demanding, which is especially problematic in a financial crisis. The study also found that the number of merger cases in which competition authorities or courts have accepted the defense is very limited. When granted, it is usually after extensive scrutiny and usually with the imposition of remedies. However, if the merger is necessary to avoid systemic failure, the EC considers that a rescue merger should be authorized when needed to prevent a worse competitive scenario. ${ }^{112}$

In crisis situations, close coordination is particularly relevant between the competition authority and the financial regulator or other agencies involved in the design and application of the interventions.

Coordination mechanisms described earlier in this document become even more important and could be channeled as part of the advocacy mandate of competition authorities. The competition authority is usually in a better position to make industry comparisons, invoke nondiscriminatory measures, ensure a level playing field, and resist political and industry pressures. However, competition authorities need the knowledge of financial regulators (particularly on potential systemic risks) who are also better positioned to make industrial policy decisions and design remedies that increase the long-term efficiency of the sector. ${ }^{113}$ During the GFC and its aftermath, the Icelandic Competition Authority became a key advocate for the use of competition-promoting interventions to address growing concentration by introducing competition impact assessment of decisions, studies of key markets including a special

\footnotetext{
${ }^{110}$ OECD 2009.

111 The failing firm defense is the argument that, although anticompetitive, a merger should be authorized when one of the merging firms is failing and likely to exit if not for the merger. Thus, deterioration of competitive conditions would not be caused by the merger; in fact, it could benefit competition compared to the counterfactual (exit of the failing firm). Failing firm defense policies usually have strict conditions including that the allegedly failing firm and its assets must exit the market in the near future absent the merger and that there must be no less anticompetitive alternative purchase than the proposed merger. (OECD 2009)

112 OECD 2009.

${ }^{113}$ Hasan and Marinč 2013.
}

focus on the financial sector. The initiative was coupled with firm merger and antitrust enforcement with special consideration of crisis consequences in market dynamics and structure. ${ }^{114}$

\subsection{CONCLUSION}

Most LA-7 competition authorities have solid competition policy institutional and legal frameworks as well as the essential enforcement and application capacities to enforce antitrust law in the banking sector. However, LA-7 economies still lag relative to more advanced jurisdictions in actively deploying the competition authorities' mandate to address competition concerns in the financial services sector. Competition authorities around the world have tackled numerous large-scale anticompetitive practices and blocked or imposed remedies on banking mergers on grounds of potential lessening of competition. In contrast, the number of anticompetitive cases in the retail banking sector prosecuted in LA-7 are low and no mergers have been blocked in the last five years or may have not been subject to review at all. Finally, advocacy initiatives to promote competition have been scarce and focused on payment systems and fintech markets.

\section{Cooperation between competition and banking} authorities has been limited. In LA-7, banking regulators often need to follow pro-competition regulatory principles. Most competition policy regimes, especially as they pertain to merger review, are nonexclusive in the sense that they require clearance by both the competition authority and the banking regulator. Mandate overlap requires effective coordination mechanisms to accommodate conflicting policy objectives. These mechanisms are not defined in the applicable legal framework in most LA-7 countries, some of which have adopted ad hoc bilateral agreements on the matter. Therefore, there is room to institutionalize and strengthen coordination mechanisms competition and banking authorities.

${ }^{114}$ World Bank Group 2016b. 
Administrative Council for the Economic Defense (CADE). 2018. "Cade Signs Memorandum of Understanding with the Central Bank of Brazil.” February 28, 2018.

http://en.cade.gov.br/press-releases/cade-signs-memorandum-of-understanding-with-the-central-bank-of-brazil.

ACCG (Australia Competition and Consumer Commission). 2008. "ACGC Not to Oppose Commonwealth Bank of Australia's Proposed Acquisition of Bank of Western Australia Ltd." December 10, 2008.

https://www.accc.gov.au/media-release/accc-not-to-oppose-commonwealth-bank-of-australias-proposed-acquisition-of-bank-of.

ACCG. 2017. "Co-operation between Competition Agencies and Regulators in the Financial Sector - Note by Australia." December 4, 2017.

https://one.oecd.org/document/DAF/COMP/WP2/ $\mathrm{WD}(2017) 3 / \mathrm{en} / \mathrm{pdf}$.

ACM (Netherlands Authority for Consumers and Markets). 2017. "Co-operation between Competition Agencies and Regulators in the Financial Sector Note by the Netherlands." December 4, 2017.

https://one.oecd.org/document/DAF/COMP/WP2/ $\mathrm{WD}(2017) 11 / \mathrm{en} / \mathrm{pdf}$.

Barth, J. R., G. J. Caprio, and R. Levine. 2013. "Bank Regulation and Supervision in 180 Countries from 1999 to 2011." J. Financ. Econ. Policy 5:111-219.

https://doi.org/10.1108/17576381311329661.

Beck, T., A. Demirgüç-Kunt, and R. Levine. 2007. "Finance, Inequality and the Poor," Journal of Economic Growth, 12(1), pp. 27-49.

Becker, G. S. 1976. "The Economic Approach to Human Behavior," University of Chicago Press, 1976.

Becker, G. S. 1983. "A Theory of Competition Among Pressure Groups for Political Influence," The Quarterly Journal of Economics Vol. 98, No. 3 (Aug): 371-400.
Besanko, D. A., and A. V. Thakor, 1992, "Banking Deregulation: Allocational Consequences of Relaxing Entry Barriers." Journal of Banking and Finance, Vol. 16, pp. 909-32.

Bundeskartellamt. 2012. "Bundeskartellamt Prohibits Haspa from Acquiring a Atake in Kreissparkasse Lauenburg." December 29, 2012.

https://www.bundeskartellamt.de/SharedDocs/Meldung/ EN/Pressemitteilungen/2012/29_02_2012_Haspa.html;jsessionid=5E54E3AB6887F360F158D9F99E4D7036.2_ cid371?nn=3591568.

Carletti, E., and A. Smolenska. 2017. "10 Years on from the Financial Crisis: Co-operation between Competition Agencies and Regulators in the Financial Sector." December 4, 2017.

https://one.oecd.org/document/DAF/COMP/ WP2(2017)8/en/pdf.

Carletti, E., P. Hartmann. 2003. "Competition and stability: what's special about banking?," in: P. Mizen (ed.), Monetary History, Exchange Rates and Financial Markets, chapter 8, Edward Elgar Publishing.

Claessens, S. 2009. "Competition in the Financial Sector: Overview of Competition Policies," IMF Working Paper No. 09/45.

CMA (Competition and Markets Authority). 2016. "Public Interest Considerations in Merger Control Note by the United Kingdom.” June 14, 2016.

http://www.oecd.org/officialdocuments/publicdisplaydocumentpdf $/$ ? cote $=\mathrm{DAF} / \mathrm{COMP} / \mathrm{WP} 3 /$ WD $(2016) 9 \&$ docLanguage $=$ En.

CMA. 2017. "Co-operation between Competition Agencies and Regulators in the Financial Sector Note by the United Kingdom.” December 4, 2017.

https://one.oecd.org/document/DAF/COMP/WP2/ WD(2017)22/en/pdf. 
COFECE. 2019. "Emplaza COFECE a agentes económicos por posibles prácticas monopólicas absolutas en el mercado de la intermediación de valores de deuda emitidos por el gobierno mexicano." October 14, 2019.

https://www.cofece.mx/emplaza-cofece-a-agentes-economicos-por-posibles-practicas-monopolicas-absolutas-en-el-mercado-de-la-intermediacion-de-valores-de-deuda-emitidos-por-el-gobierno-mexicano/.

Competition Policy International. 2019. "Brazil: CADE Investigates Banco Bradesco for Anticompetitive Practices." April 30, 2019.

https://www.competitionpolicyinternational.com/brazil-cade-investigates-banco-bradesco-for-anticompetitive-practices/.

Corvoisier, S., and R. Gropp. 2002. "Bank Concentration and Retail Interest Rates." Fournal of Banking and Finance 26 (11): 2155-2189.

https://doi.org/10.1016/S0378-4266(02)00204-2.

Covarrubias, M., G. Gutiérrez, and T. Philippon. 2020. "From Good to Bad Concentration? U.S. Industries over the Past 30 Years." NBER Macroeconomics Annual 34: 1-46. https://doi.org/10.1086/707169.

Demirgüç-Kunt, A., and R. Levine (2009). Finance and inequality: theory and evidence. World Bank Policy Research Working Paper 4967.

DOJ (U.S. Department of Justice). 2016. "Justice Department Requires Divestitures in Huntington Bancshares Incorporated's Acquisition of FirstMerit Corporation." July 13, 2016.

https://www.justice.gov/opa/pr/justice-department-requires-divestitures-huntington-bancshares-incorporated-s-acquisition.

European Commission. 2008. Communication from the Commission-The Application of State Aid Rules to Measures Taken in Relation to Financial Institutions in the Context of the Current Global Financial Crisis. https://eur-lex.europa.eu/legal-content/EN/TXT/ $\mathrm{PDF} /$ ?uri=CELEX:52008XG1025(01)\&from=EN.
European Commission. 2016. "Antitrust: Commission fines Crédit Agricole, HSBC and JPMorgan Chase $€$ 485 million for Euro Interest Rate Derivatives Cartel." December 7, 2016.

https://ec.europa.eu/commission/presscorner/detail/ en/IP_16_4304.

European Commission. 2017. "Co-operation between Competition Agencies and Regulators in the Financial Sector Note by the European Union." December 4, 2017. https://one.oecd.org/document/DAF/COMP/WP2/ $\mathrm{WD}(2017) 6 / \mathrm{en} / \mathrm{pdf}$.

FCGA (Finnish Competition and Consumer Authority). 2017. "Co-operation between Competition Agencies and Regulators in the Financial Sector Note by Finland." December 4, 2017.

https://one.oecd.org/document/DAF/COMP/WP2/ $\mathrm{WD}(2017) 7 / \mathrm{en} / \mathrm{pdf}$.

Financial Times. 2018. "Japan Clears Regional Bank Merger after Regulator Stand-off." August 24, 2018. https://www.ft.com/content/36292cee-a771-11 1e8-8ecfa7aelbeff35b.

FNE (Fiscalía Nacional Económica). 2018. "FNE prohíbe ingreso del Banco Santander a Servipag.” July 19, 2018. https://www.fne.gob.cl/fne-prohibe-ingreso-del-bancosantander-a-servipag/.

FSB (Financial Stability Board). 2019. Big Tech in Finance: Market Developments and Potential Financial Stability Implications.

https://www.fsb.org/wp-content/uploads/P091219-1.pdf

Global Competition Review. 2011. "Denmark Alters Commitment in Banking Merger." December 1, 2011. https://globalcompetitionreview.com/article/1054767/ denmark-alters-commitment-in-banking-merger.

Global Competition Review. 2012. "FCO Blocks German Banking Tie-Up.” March 5, 2012. https://globalcompetitionreview.com/article/1055229/ fco-blocks-german-banking-tie-up. 
Global Competition Review. 2016. "Brazil Clears Banco Bradesco/HSBC, But Halts Further Banking Acquisitions." June 9, 2016.

https://globalcompetitionreview.com/article/1067898/ brazil-clears-banco-bradesco-hsbc-but-halts-further-banking-acquisitions.

Global Competition Review. 2018a. "Chile Blocks Santander/ Servipag Deal.” July 25, 2018.

https://globalcompetitionreview.com/article/1172270/ chile-blocks-santander-servipag-deal.

Global Competition Review. 2018b. "Israeli Authority Considers Banking Merger.” April 25, 2018. https:// globalcompetitionreview.com/article/1168480/ israeli-authority-considers-banking-merger.

Global Competition Review. 2018c. "Banking Merger Blocked in Israel." May 31, 2018.

https://globalcompetitionreview.com/article/1170126/ banking-merger-blocked-in-israel.

Global Competition Review. 2019a. "Merger Remedies Guide Second Edition Japan.” October 14, 2019. https://globalcompetitionreview.com/insight/ merger-remedies-guide-second-edition/1209568/japan.

Global Competition Review. 2019b. "European Union: Financial Services.” July 12, 2019.

https://globalcompetitionreview.com/insight/europe-middle-east-and-africa-antitrust-review-2020/1195104/ european-union-financial-services.

Globes. 2019. "Court Overrules Regulator, Allows Mizrahi-Union Bank Merger.” November 28, 2019.

https://en.globes.co.il/en/article-court-overrules-regulator-allows-mizrahi-union-bank-mer ger-1001309037.

Hasan and Marinč. 2013. Should Competition Policy in Banking Be Amended during Crises?' Lessons from the EU. https: / / papers.ssrn.com / sol / papers. cfm?abstract_id=2289748.
Instituto Nacional de Defensa de la Competencia (INDECOPI). 2018. "Los sistemas de tarjetas de pago." November 16, 2018. https://www.indecopi.gob.pe/documents/51771/2610439/ Sistemas+de+tarjetas+de+pago/.

Jappelli, T., and M. Pagano. 2000. "Information Sharing in Credit Markets: The European Experience." Working Paper No. 35 (March 2000), Centre for Studies in Economics and Finance.

Kroes, N. 2010. Competition Policy and the Crisis-the Commission's Approach to Banking and Beyond.

https://ec.europa.eu/competition/publications / cpn/2010_1_1.pdf.

La República. 2019. "Los activos de los conglomerados representan 77\% del sistema financiero.” June 6, 2019. https://www.larepublica.co/finanzas/los-activos-de-los-conglomerados-representan-77-del-sistema-financiero-2870385.

Laffont,J.J., and J. Tirole. 1991. "The Politics of Government Decision-Making: A Theory of Regulatory Capture," The Quarterly Journal of Economics 106 (4): 1089-1127.

Levine, R. 2005. "Finance and growth: theory and evidence," Handbook of Economic Growth, 1, pp. 865-934.

Mayer Brown. 2018. Brazil: "CADE and BACEN Sign a Memorandum of Understanding." March 5, 2018.

https: / / www.mayerbrown.com/en / perspectives-events/publications/2018/03/ brazil-cade-and-bacen-sign-a-memorandum-of-underst.

Monopolkommission. 2012. "Eine Wettbewerbsordnung für die Finanzmärkte - Zwanzigstes Hauptgutachten der Monopolkommission gemäß $§ 44$ Abs. 1 Satz 1 GWB." July 19, 2014.

https://www.monopolkommission.de/images/PDF/HG/ HG20/HG_XX_gesamt.pdf.

NS Banking. 2019. "How RBS Bail-out is Now Helping SME Banking Competition in the UK." March 14, 2019. h t tps : / / w w w. n s banking. com / n e w s / alternative-remedies-package-rbs-bailout/. 
OECD (Organisation for Economic Co-operation and Development). 2002. "Portfolio Effects in Conglomerate Mergers.” January 24, 2002.

http://www.oecd.org/competition/mergers/1818237.pdf.

OECD. 2009. The Failing Firm Defence. August 10, 2010. https://www.oecd.org/competition/mergers/45810821.pdf.

OECD. 2011. Crisis Cartels. October 18, 2011. http://www.oecd.org/daf/competition/cartels/48948847. pdf.

OECD. 2015. Efficiency and Contestability in the Colombian Banking System. April 15, 2015.

https://www.oecd-ilibrary.org/docserver/5js30twjgm61-en.pdf? expires $=1586292213 \& \mathrm{id}=\mathrm{id} \&$ accname $=\mathrm{gu}$ est\&checksum=4A36411B23A4EA7E2D532A1B82084F7C.

OECD. 2016a. Public Interest Considerations in Merger Control. June 14, 2016. http://www.oecd.org/officialdocuments/publicdisplaydocumentpdf/?cote=DAF/COMP/ WP3(2016)3\&docLanguage $=$ En .

OECD. 2016b. Colombia: Assessment of Competition Law and Policy. 2016.

https://www.oecd.org/daf/competition/Colombia-assessment-competition-report-2016.pdf

OECD. 2019a. Digital Disruption in Financial MarketsNote by Peru. June 5, 2019.

https://one.oecd.org/document/DAF/COMP/ WD(2019)56/en/pdf.

OECD. 2019b. Annual Report on Competition Policy Developments in Israel-2018. June 5, 2019.

https://www.gov.il/BlobFolder/reports/annualreport2018/ en/englishsite_Annual\%20report\%202018.pdf.

Padilla, A. Jorge, and Marco Pagano. 2000. "Sharing default information as a borrower discipline device," European Economic Review 44 (10): 1951-1980

Padilla, A. Jorge, and Marco Pagano. 1997. "Endogenous Communication Among Lenders and Entrepreneurial Incentives." The Review of Financial Studies 10 (Spring): 205-236.
Pagano, M., and Tullio Jappelli. 1993. "Information Sharing in Credit Markets." The Fournal of Finance 43: 1693-1718.

Philippon, T. 2019. The Great Reversal: How America Gave Up on Free Markets.

Posner, R. A. 1988. "The Economics of Trademark Law," The Trademark Reporter 78 (3): 267-306.

Posner, R. A. 1974. "Exclusionary Practices and the Antitrust Laws," University of Chicago Law Review 41 (3): 506-535.

Ratnovski, L. 2013. "Competition Policy for Modern Banks." Working Paper (No. WP/13/126), IMF. https://doi.org/10.5089/9781484354728.001.

Reuters. 2016. "Bradesco Wins Brazil Approval for $\$ 5.2$ Billion Purchase of HSBC Unit.” June 8, 2016.

https://www.reuters.com/article/us-hsbc-bank-brasil-ma-banco-bradesco-a-idUSKCNOYU2JV.

SFG (Superintendencia Financiera de Colombia). 2018. Conglomerados Financieros. November 27, 2018.

https://www.superfinanciera.gov.co/descargas/institucional/pubFile1035810/20181127socializacionleyconglomeradosfinancieros.pptx.

SFC. 2019a. Esquema de Supervisión de los Conglomerados Financieros en Colombia.

https://www.superfinanciera.gov.co/descargas/institucional/ pubFile1035653/Documentotecnicoconglomerados.pdf.

SFC. 2019b. Todo listo en la Superfinanciera para asumir la supervisión de los 13 conglomerados financieros. https://www.superfinanciera.gov.co/jsp/10099616.

Stigler, G.J. 1971. "The Theory of Economic Regulation," The Bell Journal of Economics and Management Science 2 (1): 3-21.

Stiglitz, J. E. and A. Weiss. 1981. "Credit Rationing in Markets with Imperfect Information," American Economic Review, 71(3), pp. 393-410. 
Teledoce. 2015. Bergara dijo que el proceso de fusión y concentración de Bancos fortalece la competencia. November 9, 2015.

https://www.teledoce.com/telemundo/nacionales/bergara-dijo-que-el-proceso-de-fusion-y-concentracion-de-bancos-fortalece-la-competencia/.

Vanguardia. 2019. Cofece encuentra evidencia de manipulación de bancos en mercado de bonos. October 11, 2019. https:// vanguardia.com.mx/articulo/cofece-encuentra-evidencia-de-manipulacion-de-bancos-en-mercado-de-bonos.

World Bank Group. 2013. Global Financial Development Report: Rethinking the Role of the State in Finance. September 17, 2012.

http://siteresources.worldbank.org/EXTGLOBALFINREPORT/Resources/8816096-1346865433023/88270781346865457422/GDF_2013_Report.pdf.

World Bank Group. 2016a. Competition in the GCC SME Lending Markets: An Initial Assessment.

h t tps: / / openknowledge.worldbank.org / handle/10986/25404.

World Bank Group. 2016b. Transforming Markets through Competition: New Developments and Recent Trends in Competition Advocacy.

http:/ / documents.worldbank.org / curated / en/640191467990945906/pdf/104806-REPF-Transforming-Markets-Through-Competition.pdf.

World Bank Group. 2019. Bank Regulation and Supervision Ten Years after the Global Financial Crisis. October 2019. http: / / documents.worldbank.org / curated / en/685851571160819618/pdf/Bank-Regulation-and-Supervision-Ten-Years-after-the-Global-Financial-Crisis.pdf. 



\section{ANNEX I:}

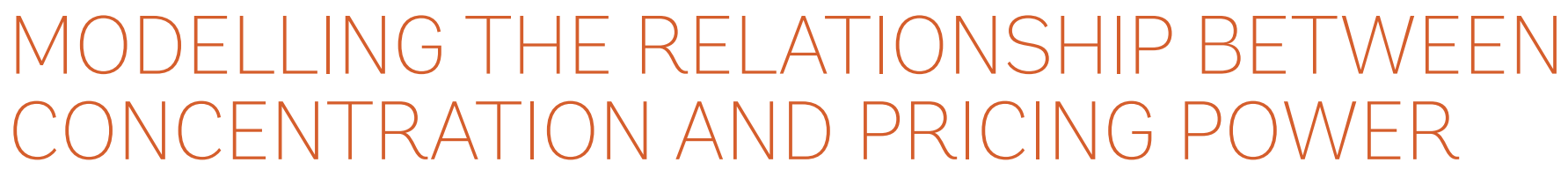

Our key objective is to relate measures of product concentration to bank pricing. In this regard, it is indispensable to have information on prices (that is, rates) and volumes for each product across countries over time. Thus, we select three credit products (personal [uncollateralized] loans, credit cards, and mortgages) and one deposit funding product (term deposits). In line with Corvoisier and Gropp (2002), we relate concentration to contractual interest margins using the following specification:

\section{Equation (A1)}

$$
\begin{gathered}
\text { Margin }_{i p c}=\beta_{0}+\sum_{i} \beta_{1 i} \text { IShare }_{i p c}+\sum_{i} \beta_{2 i} \text { Risk }_{i c}+\sum_{i} \beta_{3 i} \text { OpCost }_{i c}+\sum_{i} \beta_{4 i} \text { DEM }_{c}+ \\
\sum_{i} \beta_{5 i} \text { SUBST }_{c}+\sum_{i} \beta_{6 i} \text { BankChar }_{i c}+\alpha_{p}+\varepsilon_{p t}
\end{gathered}
$$

where the subscripts $i, p$, and $c$ stand for a bank, product, and country, respectively. Margin is defined as the markup (lending products: personal loans, credit cards, and mortgages) or markdown (term deposits) over the money market rate. $I$ is an indicator variable that takes the value 1 for a specific product, 0 otherwise. Share is a bank share on an individual product market. ${ }^{15}$ Risk is the net provisions over total assets. OpCost captures operational efficiency computed as administrative expenses over total assets. DEM refers to two variables that capture the aggregate loan demand proxied by the consumer and producer confidence indexes. SUBST accounts for the elasticity of the aggregate loan demand. BankChar refers to two basic bank-specific characteristics: government ownership and size (natural logarithm of total assets). Standard errors are clustered at the product level. $\alpha_{p}$ is the product fixed effects. The descriptive statistics of the main variables at the bank level used in the regression are given in Table Al.

Results from estimations of Equation (A1) are reported in Table A2.

We also run the regression separately for each country. Results are reported in Table A3.

\footnotetext{
${ }^{115}$ By multiplying the indicator variable for the market share in each product, we obtain product-specific continuous variables that take value of the market share of each bank in that specific product, 0 otherwise. Thus, in Table A2, column 2, we have two continuous variables truncated at 0 for deposits (Dep_Share) and loans (Loan_Share); in Table A2, column 4, we have four continuous variables truncated at 0 for term deposits (Share TD), personal loans (Share PL), credit cards (Share $\mathrm{CC}$ ), and mortgages (Share MTG).
} 
TABLE A1: DESCRIPTIVE STATISTICS BANK-LEVEL VARIABLES

PANEL A: DESCRIPTIVE STATISTICS

\begin{tabular}{l|c|c|c|c|c|c|}
\hline Variable & Symbol & N & Mean & SD & Min & Max \\
\hline Markdown term deposit & Margin TD & 776 & 0.041 & 1.557 & -13.317 & 6.059 \\
Markup personal loans & Margin PL & 694 & 21.047 & 24.862 & -7.530 & 253.370 \\
Markup credit cards & Margin CG & 711 & 85.549 & 135.345 & 4.295 & 779.220 \\
Markup mortgages & Margin MTG & 436 & 5.964 & 3.080 & -4.009 & 23.394 \\
Bank share term deposit & Share TD & 964 & 4.149 & 5.193 & 0.000 & 29.533 \\
Bank share personal loans & Share PL & 1,205 & 3.900 & 6.103 & 0.000 & 34.746 \\
Bank share credit cards & Share CC & 849 & 5.536 & 8.498 & 0.000 & 52.360 \\
Bank share mortgages & Share MTG & 692 & 5.347 & 10.405 & 0.000 & 77.739 \\
Net provisions & Risk & 1,699 & 0.016 & 0.035 & 0.000 & 0.945 \\
Cost to income & OpCost & 1,699 & 0.043 & 0.068 & 0.000 & 0.629 \\
Natural log of total assets & Size & 1,699 & 13.357 & 3.249 & 4.329 & 21.124 \\
\hline
\end{tabular}

Note: The minimum values for bank shares in term deposits, personal loans, credit cards, and mortgages are 0.00000005, 0.000001, 0.0000005, and 0.000002, respectively.

\section{PANEL B: CORRELATION MATRIX}

\section{Variable}

\begin{tabular}{|c|c|c|c|c|c|c|c|c|c|c|c|}
\hline Margin TD & 1 & & & & & & & & & & \\
\hline Margin PL & $-0.183^{*}$ & 1 & & & & & & & & & \\
\hline Margin CC & $-0.322^{*}$ & $0.756^{*}$ & 1 & & & & & & & & \\
\hline Margin MTG & $-0.257^{*}$ & $0.178^{*}$ & $-0.265^{*}$ & 1 & & & & & & & \\
\hline Share TD & $0.132^{*}$ & $-0.097 *$ & -0.041 & 0.011 & 1 & & & & & & \\
\hline Share PL & $0.130^{*}$ & -0.040 & -0.046 & -0.039 & $0.695^{*}$ & 1 & & & & & \\
\hline Share CG & $0.203^{*}$ & $-0.141^{*}$ & 0.016 & -0.082 & $0.609 *$ & $0.717^{*}$ & 1 & & & & \\
\hline Share MTG & $0.193^{*}$ & $-0.088^{*}$ & -0.057 & -0.079 & $0.833^{*}$ & 0.496* & $0.401^{*}$ & 1 & & & \\
\hline Risk & $-0.217^{*}$ & $0.612^{*}$ & 0.027 & $0.079 *$ & $-0.127^{*}$ & -0.012 & -0.049 & $-0.098^{*}$ & 1 & & \\
\hline OpCost & $-0.162^{*}$ & $0.660^{*}$ & $-0.074^{*}$ & 0.029 & $-0.248^{*}$ & -0.046 & $-0.117^{*}$ & $-0.161 *$ & $0.555^{*}$ & 1 & \\
\hline Size & $0.071^{*}$ & $-0.343^{*}$ & $0.322^{*}$ & -0.032 & $0.436^{*}$ & $0.248^{*}$ & $0.216^{*}$ & $0.241^{*}$ & $-0.262^{*}$ & $-0.482^{*}$ & 1 \\
\hline
\end{tabular}

Note: * represent statistical significance at 10 percent level. 
TABLE A2: ESTIMATIONS WITH PRODUCT FIXED EFFECTS

\begin{tabular}{|c|c|c|c|}
\hline Variables & $\begin{array}{c}(1) \\
\text { Margin }\end{array}$ & $\begin{array}{c}(2) \\
\text { Margin }\end{array}$ & $\begin{array}{c}(3) \\
\text { Margin }\end{array}$ \\
\hline Share & $\begin{array}{c}1.006^{* * * *} \\
(0.334)\end{array}$ & & \\
\hline Dep_Share & & $\begin{array}{c}1.312^{* * * *} \\
(0.342)\end{array}$ & \\
\hline Loan_Share & & $\begin{array}{c}0.941 * * * \\
(0.359)\end{array}$ & \\
\hline Share TD & & & $\begin{array}{c}1.285^{* * * *} \\
(0.330)\end{array}$ \\
\hline Share PL & & & $\begin{array}{c}0.217 \\
(0.259)\end{array}$ \\
\hline Share CG & & & $\begin{array}{l}1.305^{* *} \\
(0.627)\end{array}$ \\
\hline Share MTG & & & $\begin{array}{c}0.659 * * * \\
(0.204)\end{array}$ \\
\hline Domestic private bank & $\begin{array}{l}-10.289 \\
(11.786)\end{array}$ & $\begin{array}{l}-10.848 \\
(11.787)\end{array}$ & $\begin{array}{l}-7.897 \\
(11.375)\end{array}$ \\
\hline Foreign owned bank & $\begin{array}{l}-14.492 \\
(11.589)\end{array}$ & $\begin{array}{l}-14.313 \\
(11.572)\end{array}$ & $\begin{array}{l}-12.056 \\
(11.088)\end{array}$ \\
\hline Risk & $\begin{array}{c}272.271^{* * * *} \\
(62.976)\end{array}$ & $\begin{array}{c}259.207^{* * * *} \\
(58.955)\end{array}$ & $\begin{array}{c}212.233^{* * * *} \\
(56.261)\end{array}$ \\
\hline OpCost & $\begin{array}{c}85.103^{* * * *} \\
(21.241)\end{array}$ & $\begin{array}{c}89.090^{* * * *} \\
(19.295)\end{array}$ & $\begin{array}{c}82.627 * * * * \\
(19.023)\end{array}$ \\
\hline Size & $\begin{array}{c}0.907 \\
(0.979)\end{array}$ & $\begin{array}{c}0.150 \\
(1.034)\end{array}$ & $\begin{array}{c}0.246 \\
(0.991)\end{array}$ \\
\hline Consumer confidence & $\begin{array}{c}-0.217 * * * \\
(0.062)\end{array}$ & $\begin{array}{c}-0.183 * * * \\
(0.061)\end{array}$ & $\begin{array}{c}-0.150 * * \\
(0.059)\end{array}$ \\
\hline Producer confidence & $\begin{array}{c}1.600^{* * * *} \\
(0.255)\end{array}$ & $\begin{array}{c}1.344 * * * \\
(0.262)\end{array}$ & $\begin{array}{c}1.399 * * * \\
(0.254)\end{array}$ \\
\hline Total banking assets ( $\%$ GDP) & $\begin{array}{c}2.991 * * * \\
(0.220)\end{array}$ & $\begin{array}{c}2.932^{* * *} \\
(0.221)\end{array}$ & $\begin{array}{c}2.650 * * * \\
(0.210)\end{array}$ \\
\hline $\begin{array}{l}\text { Stock mkt capitalization } \\
(\% \text { GDP })\end{array}$ & $\begin{array}{c}-1.021 * * * \\
(0.098)\end{array}$ & $\begin{array}{c}-1.057 * * * \\
(0.098)\end{array}$ & $\begin{array}{c}-1.084^{* * * *} \\
(0.093)\end{array}$ \\
\hline Constant & $\begin{array}{c}-134.193^{* * * *} \\
(24.674) \\
\end{array}$ & $\begin{array}{c}-125.809 * * * \\
(24.958) \\
\end{array}$ & $\begin{array}{c}-120.236^{* * * *} \\
(23.975) \\
\end{array}$ \\
\hline Observations & 2,378 & 2,378 & 2,378 \\
\hline R-squared & 0.454 & 0.466 & 0.501 \\
\hline Product FE & Yes & Yes & Yes \\
\hline
\end{tabular}

Note: Standard errors corrected for heteroscedasticity appear in parentheses. *, **, and *** represent statistical significance at 10 percent, 5 percent, and 1 percent two-tailed level, respectively. 
TABLE A3: COUNTRY REGRESSIONS WITH PRODUCT FIXED EFFECTS

\begin{tabular}{|c|c|c|c|c|c|}
\hline Variables & $\begin{array}{c}(1) \\
\text { Margin } \\
\text { Brazil }\end{array}$ & $\begin{array}{c}(2) \\
\text { Margin } \\
\text { Chile }\end{array}$ & $\begin{array}{c}(3) \\
\text { Margin } \\
\text { Colombia }\end{array}$ & $\begin{array}{c}(4) \\
\text { Margin } \\
\text { Mexico }\end{array}$ & $\begin{array}{c}(5) \\
\text { Margin } \\
\text { Peru }\end{array}$ \\
\hline Share & & & $\begin{array}{c}-1.417^{* * * *} \\
(0.208)\end{array}$ & $\begin{array}{c}-0.748^{* * * *} \\
(0.128)\end{array}$ & $\begin{array}{c}-2.070^{* * * *} \\
(0.253)\end{array}$ \\
\hline Share PL & $\begin{array}{c}0.526 * * * \\
(0.178)\end{array}$ & $\begin{array}{c}0.369 * * * \\
(0.094)\end{array}$ & $\begin{array}{c}0.588 * * * * \\
(0.100)\end{array}$ & $\begin{array}{c}0.810 * * * \\
(0.082)\end{array}$ & $\begin{array}{c}0.784^{* * * *} \\
(0.157)\end{array}$ \\
\hline Share CG & $\begin{array}{c}-0.084 \\
(0.073)\end{array}$ & & & $\begin{array}{c}-0.195 * * \\
(0.095)\end{array}$ & $\begin{array}{c}-0.643^{* * * *} \\
(0.128)\end{array}$ \\
\hline Share MTG & $\begin{array}{l}28.393 \\
(27.472)\end{array}$ & $\begin{array}{l}-2.639 \\
(2.099)\end{array}$ & $\begin{array}{c}2.268 \\
(1.731)\end{array}$ & & \\
\hline Domestic private bank & $\begin{array}{c}15.945 \\
(28.052)\end{array}$ & $\begin{array}{c}-7.070 * * * \\
(2.168)\end{array}$ & $\begin{array}{c}2.307 \\
(1.793)\end{array}$ & $\begin{array}{c}-4.937 * * * \\
(1.022)\end{array}$ & $\begin{array}{c}2.060 \\
(1.563)\end{array}$ \\
\hline Foreign owned bank & $\begin{array}{c}1,618.808 \\
(2,088.051)\end{array}$ & $\begin{array}{c}256.213^{* * * *} \\
(87.729)\end{array}$ & $\begin{array}{c}98.395^{* * * *} \\
(36.042)\end{array}$ & $\begin{array}{c}34.418 \\
(26.165)\end{array}$ & $\begin{array}{c}347.238 * * \\
(174.727)\end{array}$ \\
\hline Risk & $\begin{array}{c}1,391.496 \\
(1,903.238)\end{array}$ & $\begin{array}{c}-149.893^{*} \\
(87.551)\end{array}$ & $\begin{array}{c}-66.437 * * * \\
(18.527)\end{array}$ & $\begin{array}{c}55.264^{* * * *} \\
(13.563)\end{array}$ & $\begin{array}{l}159.904 * \\
(90.469)\end{array}$ \\
\hline OpCost & $\begin{array}{l}10.409 \\
(7.863)\end{array}$ & $\begin{array}{c}-0.923 \\
(0.700)\end{array}$ & $\begin{array}{c}1.446^{* * * *} \\
(0.501)\end{array}$ & $\begin{array}{c}0.948 * * * \\
(0.325)\end{array}$ & $\begin{array}{c}5.087 * * * * \\
(1.313)\end{array}$ \\
\hline Size & $\begin{array}{l}-1.201 \\
(2.411)\end{array}$ & $\begin{array}{c}0.604 \\
(0.451)\end{array}$ & $\begin{array}{c}0.029 \\
(0.035)\end{array}$ & $\begin{array}{c}1.968^{* * * *} \\
(0.698)\end{array}$ & $\begin{array}{c}0.214 \\
(0.599)\end{array}$ \\
\hline Consumer confidence & $\begin{array}{l}-3.462 \\
(5.856)\end{array}$ & $\begin{array}{l}0.475^{*} \\
(0.282)\end{array}$ & $\begin{array}{l}-0.047 \\
(0.082)\end{array}$ & $\begin{array}{c}0.078 \\
(0.187)\end{array}$ & \\
\hline Producer confidence & $\begin{array}{l}-2.392 \\
(10.513)\end{array}$ & $\begin{array}{c}1.136 \\
(1.008)\end{array}$ & $\begin{array}{l}-0.114 \\
(0.122)\end{array}$ & $\begin{array}{l}0.131 \\
(0.132)\end{array}$ & $\begin{array}{c}-0.232 \\
(0.243)\end{array}$ \\
\hline Total banking assets (\% GDP) & $\begin{array}{c}4.653 \\
(5.957)\end{array}$ & $\begin{array}{l}-0.257 \\
(0.155)\end{array}$ & $\begin{array}{l}-0.010 \\
(0.043)\end{array}$ & $\begin{array}{c}-0.304 * * \\
(0.121)\end{array}$ & $\begin{array}{l}-0.113 \\
(0.138)\end{array}$ \\
\hline Stock mkt capitalization (\% GDP) & & $\begin{array}{c}-0.042 \\
(0.106)\end{array}$ & $\begin{array}{c}-0.142 \\
(0.120)\end{array}$ & $\begin{array}{c}1.792 * * * \\
(0.304)\end{array}$ & $\begin{array}{l}-0.181 \\
(0.203)\end{array}$ \\
\hline Constant & $\begin{array}{c}368.987 \\
(1,238.220)\end{array}$ & $\begin{array}{l}-115.317 \\
(118.962)\end{array}$ & $\begin{array}{c}-4.708 \\
(10.771)\end{array}$ & $\begin{array}{c}-198.278^{* * * *} \\
(62.395)\end{array}$ & $\begin{array}{l}-40.645 \\
(37.583)\end{array}$ \\
\hline Observations & 172 & 151 & 530 & 1,063 & 462 \\
\hline R-squared & 0.363 & 0.331 & 0.493 & 0.313 & 0.417 \\
\hline Product FE & Yes & Yes & Yes & Yes & Yes \\
\hline
\end{tabular}

In ancillary regressions, we also employ panel data analysis and construct a dataset where for each bank and year we related market share in a product to the relative margins. The specification is as follows:

\section{Equation (A2)}

$$
\begin{aligned}
\text { Margin }_{i p t c}= & \beta_{0}+\sum_{i} \beta_{1 i} \text { Share }_{i p t c}+\sum_{i} \beta_{2 i} \text { Risk }_{i t c}+\sum_{i} \beta_{3 i} \text { OpCost }_{i t c}+\sum_{i} \beta_{4 i} \text { DEM }_{c t} \\
& +\sum_{i} \beta_{5 i} \text { SUBST }_{c t}+\sum_{i} \beta_{6 i} \text { BankChar }_{i t c}+\alpha_{i}+\alpha_{t}+\varepsilon_{p t},
\end{aligned}
$$

where all the variables are as per equation (A1) except that the observational unit is now a bank and the time dimension a year. We also include bank $\left(\alpha_{i}\right)$ and time $\left(\alpha_{t}\right)$ fixed effects. Results are given in Table A4. 


\begin{tabular}{|c|c|c|c|c|c|c|c|c|c|c|c|c|c|c|c|c|c|c|}
\hline बㄹ & & & & 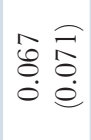 & & & 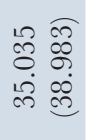 & 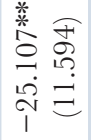 & 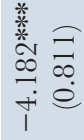 & 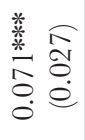 & 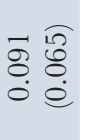 & 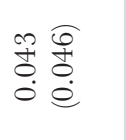 & 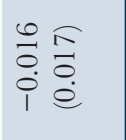 & 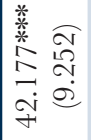 & $\widehat{\omega}$ & & $\stackrel{\circ}{z}$ & $\sum^{\frac{0}{2}}$ \\
\hline 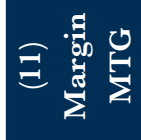 & & & & 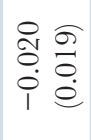 & 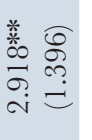 & 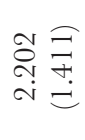 & 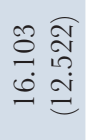 & 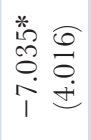 & 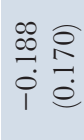 & 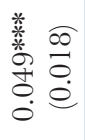 & 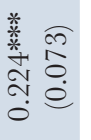 & 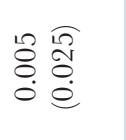 & 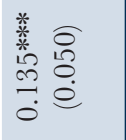 & 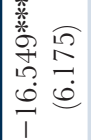 & के & $\frac{\infty}{m}$ & 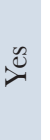 & z̊ \\
\hline 宅 & & & & 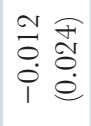 & 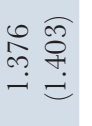 & 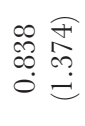 & 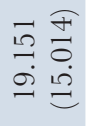 & 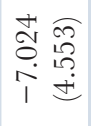 & 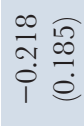 & $\begin{array}{ll}* & 0 \\
0 & 0 \\
0 & 0 \\
0 & 0 \\
0 & 0\end{array}$ & 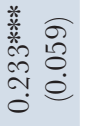 & 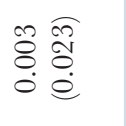 & 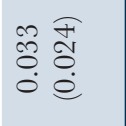 & $\begin{array}{l}0 \\
0 \\
0 \\
0 \\
0 \\
i \\
i\end{array}$ & के & $\begin{array}{l}\widehat{a} \\
\overrightarrow{0}\end{array}$ & そ̊ & $\stackrel{8}{8}$ \\
\hline ब & & & 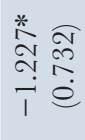 & & 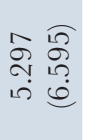 & & 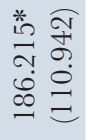 & 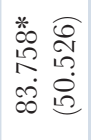 & 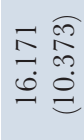 & 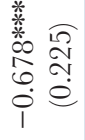 & 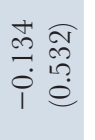 & 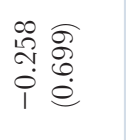 & 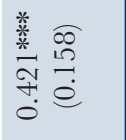 & 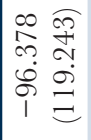 & $\overrightarrow{0}$ & 冚 & $\stackrel{2}{\check{z}}$ & 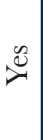 \\
\hline ब & & & 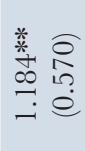 & & 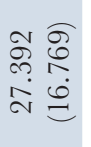 & 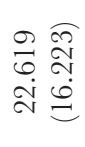 & 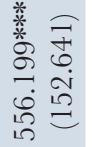 & 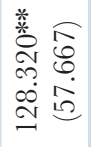 & 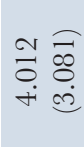 & 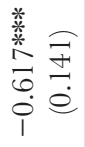 & 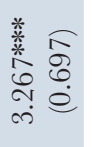 & 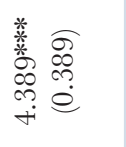 & 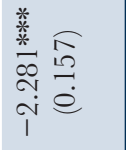 & 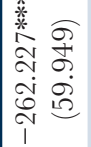 & $\stackrel{\infty}{0}$ & $\begin{array}{l}\infty \\
\infty \\
0 \\
0 \\
0\end{array}$ & $\check{\beth}^{\varkappa}$ & $\stackrel{\circ}{\not}$ \\
\hline 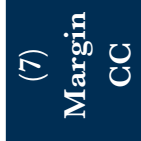 & & & 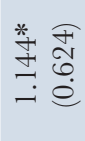 & & $\begin{array}{l}100 \\
0.00 \\
0.0 \\
\dot{0}\end{array}$ & 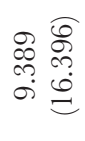 & 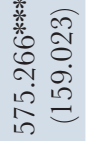 & 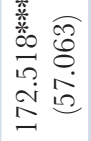 & 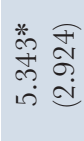 & 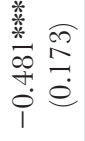 & 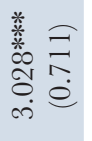 & 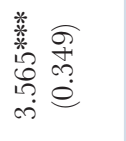 & 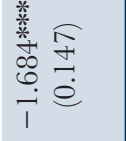 & 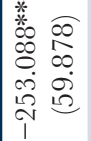 & $\grave{0}$ & $\begin{array}{l}8 \\
0 \\
0 \\
0 \\
0\end{array}$ & z̊ & ¿̊ \\
\hline 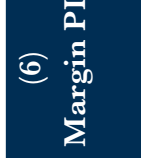 & & 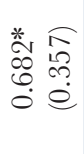 & & & 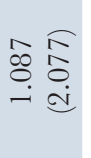 & & 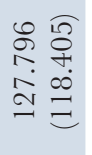 & 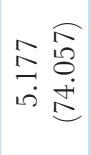 & $\begin{array}{l}80 \\
8 \\
\text { o } \\
\text { in t }\end{array}$ & 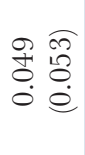 & $\begin{array}{ll}0 & 0 \\
= & 0 \\
0 & 0 \\
0 & 0\end{array}$ & 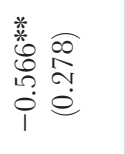 & 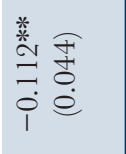 & 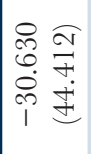 & $\frac{m}{6}$ & $\begin{array}{l}\text { ⿵े } \\
\text { ڤे } \\
\text { ᄋ }\end{array}$ & 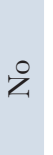 & $\underbrace{\infty}$ \\
\hline 墭 & & 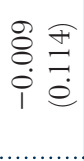 & & & $\begin{array}{ll}4 & \\
\infty & 0 \\
00 & 0 \\
i & 0 \\
1 & \stackrel{0}{=}\end{array}$ & 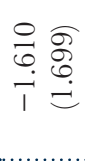 & 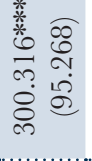 & 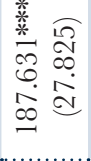 & 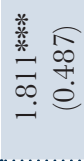 & 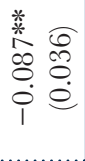 & 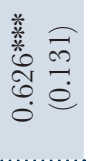 & $\begin{array}{l}\stackrel{g}{\widehat{N}} \\
\stackrel{\mathrm{N}}{0} \\
\stackrel{0}{e}\end{array}$ & 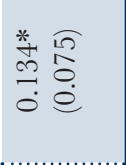 & 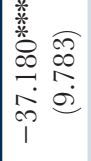 & $\frac{1}{6}$ & 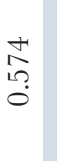 & $\overbrace{}^{\infty}$ & ฉ̊ \\
\hline ङ & & 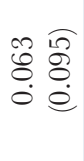 & & & 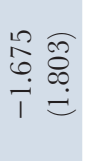 & 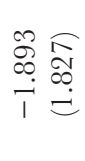 & 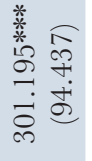 & 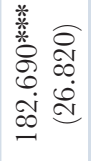 & 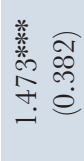 & 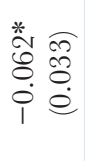 & 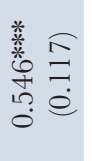 & 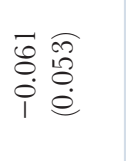 & 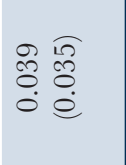 & 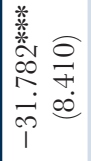 & $\frac{1}{6}$ & 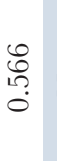 & $\stackrel{\circ}{\not}$ & ฉ̊ \\
\hline 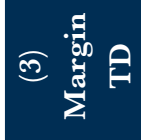 & 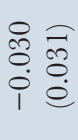 & & & & 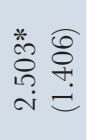 & & 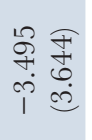 & 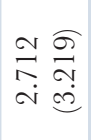 & 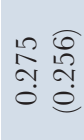 & 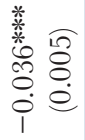 & 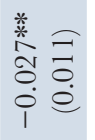 & 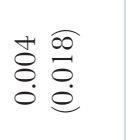 & 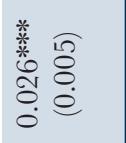 & 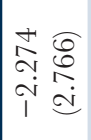 & 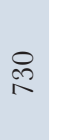 & 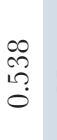 & z̊ & $\nu^{2}$ \\
\hline ब营 & $\begin{array}{ll}10 & \pi \\
0 & 0 \\
0 & 0 \\
0 & 0\end{array}$ & & & & 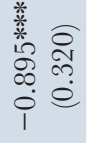 & 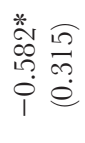 & 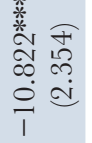 & 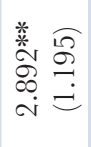 & 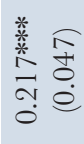 & 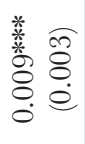 & $\begin{array}{ll}m & \\
0 & 0 \\
0 & 0 \\
1 & 0\end{array}$ & 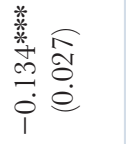 & 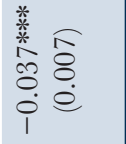 & 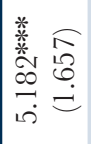 & 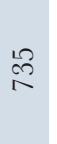 & $\begin{array}{l}\vec{n} \\
\text { ?े } \\
0\end{array}$ & $\overbrace{}^{\varkappa}$ & $\stackrel{8}{2}$ \\
\hline 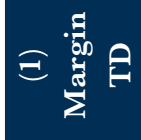 & 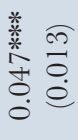 & & & & 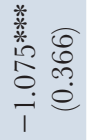 & 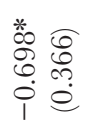 & 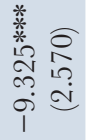 & 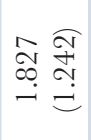 & 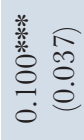 & 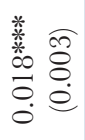 & 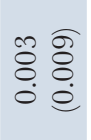 & $\begin{array}{l}\infty \\
\stackrel{a}{a} \\
\stackrel{0}{0} \\
\dot{e}\end{array}$ & 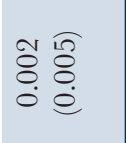 & 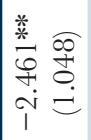 & $\stackrel{\infty}{\sim}$ & $\begin{array}{l}\stackrel{2}{2} \\
\stackrel{2}{1} \\
0\end{array}$ & z̊ & z̊ \\
\hline 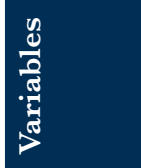 & 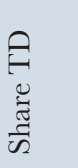 & 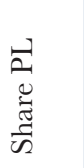 & $\begin{array}{l}0 \\
0 \\
\bar{\Xi} \\
\bar{\Xi}\end{array}$ & 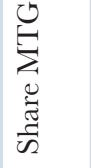 & 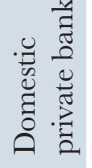 & 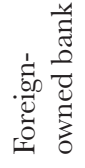 & $\frac{y}{a n}$ & $\begin{array}{l}0_{0}^{2} \\
0^{2} \\
0\end{array}$ & $\stackrel{N}{\mathscr{N}}$ & 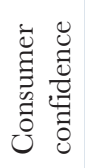 & 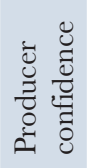 & 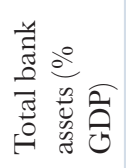 & 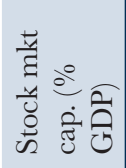 & 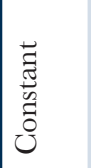 & 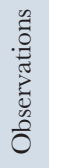 & 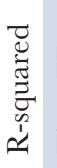 & Eี & $\begin{array}{l}\text { Tr } \\
\text { जै } \\
\text { है }\end{array}$ \\
\hline
\end{tabular}





\section{ANNEX II:}

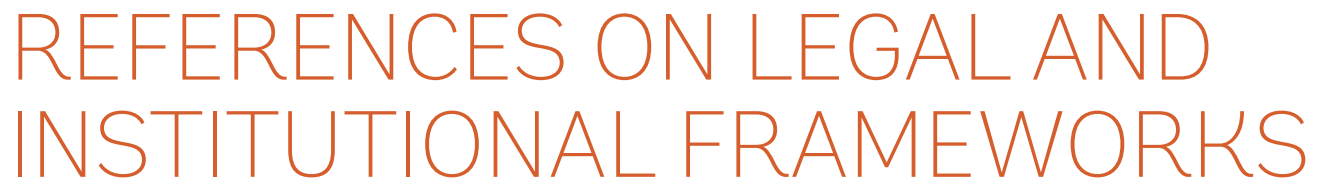

Argentina: General Competition Law (Law 27442) is enforced by the Autoridad Nacional de Competencia (ANC). The central bank mandate includes the defense of competition in coordination with the ANC and issuing of regulations to preserve competition in the financial sector (Art. $4(\mathrm{~h})$ and 14(t) of Law 24.144, respectively).

Brazil: General Competition Law (Law 12,529/11) is enforced by CADE. The central bank also has merger review authority under the Banking Law (Law 4595/64).

Ghile: General Competition Law (Decree Law 211) is enforced by the Fiscalía Nacional Económica (FNE). Mergers in the banking sector also need to be cleared by the Comisión para el Mercado Financiero, the banking sector regulator (art. 35 Decree Law 3), to address financial stability concerns and considering the systemic relevance of the parties involved in the merger.

Colombia: General Competition Law (Law 1340 is enforced by SIC. If the merger exclusively involves parties under the supervision of the SFC, the banking sector regulator, then the merger must be cleared by the regulator with an opinion from SIC regarding (a) the impact on competition of the merger and (b) any conditions for approval if needed (Law 155). The General Competition Law also includes an exemption for bankruptcy protection measures ordered by the banking sector regulator for both anticompetitive practices and merger review (Art. 28, Law 1340).

Mexico: General Competition Law (Ley Federal de Competencia Económica) is enforced by COFECE. Mergers also need to be cleared by the Comisión Nacional Bancaria y de Valores, the banking sector regulator.

Peru: General Competition Law (Legislative Decree 1034) is enforced by INDECOPI. Mergers must be authorized by INDECOPI and SBS, the banking regulator (Art. 12, Law 26702). If there are imminent and relevant risks to the stability of the system, only SBS authorization is needed (Urgency Decree 013-2019).

Uruguay: General Competition Law (Law 18.159) is enforced by the Comisión de Promoción $y$ Defensa de la Competencia, except where there is a specialized regulatory agency. The law is cross-sectoral and includes the banking sector. The central bank enforces competition law in the banking sector (Art. 27, Law 18.159). 


\section{(4) WORLD bank Group}

1818 H Street, NW

Washington, D.C. 20433 USA

Telephone: 202-473-1000

Internet: www.worldbank.org 